\title{
MANAJEMEN KURIKULUM DI SEKOLAH
}

\section{Modul Pembelajaran Program Studi Administrasi Pendidikan STKIP Muhammadiyah Bogor}

\section{Wahyu Bagja Sulfemi}

\section{BOGOR \\ VISI NUSANTARA MAJU \\ 2018}




\section{KATA PENGANTAR}

Dengan menyebut nama Allah SWT yang Maha Pengasih lagi Maha Panyayang, Kami panjatkan puja dan puji syukur atas kehadirat-Nya, yang telah melimpahkan rahmat, hidayah, dan inayah-Nya kepada kami, sehingga kami dapat menyelesaikan buku tentang Manajemen Kurikulum.

Buku ini telah kami susun dengan maksimal dan mendapatkan bantuan dari berbagai pihak sehingga dapat memperlancar pembuatan makalah ini. Untuk itu kami menyampaikan banyak terima kasih kepada semua pihak yang telah berkontribusi dalam pembuatan buku ini

Terlepas dari semua itu, Kami menyadari sepenuhnya bahwa masih ada kekurangan baik dari segi susunan kalimat maupun tata bahasanya. Oleh karena itu dengan tangan terbuka kami menerima segala saran dan kritik dari pembaca agar kami dapat memperbaiki makalah ilmiah ini.

Akhir kata kami berharap semoga buku ilmiah tentang Manajemen Kurikulum ini dapat memberikan manfaat maupun inpirasi terhadap pembaca.

Bogor, 20 Desember 2018

Penulis

Wahyu Bagja Sulfemi 


\section{DAFTAR ISI}

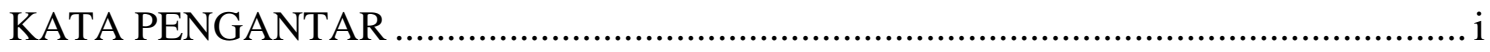

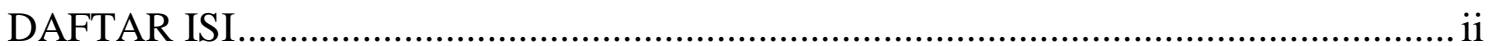

\section{BAB I PENDAHULUAN}
A. Latar belakang. 1

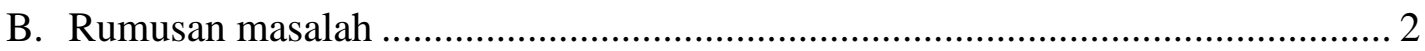

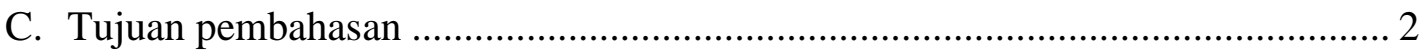

\section{BAB II PEMBAHASAN}

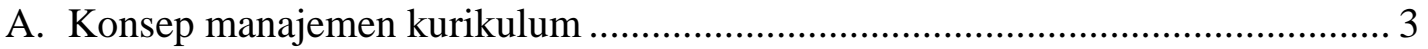

B. Ruang lingkup manajemen kurikulum lembaga pendidikan ............................. 12

C. Masalah-masalah dan kendala dalam implementasi kurikulum ....................... 10

D. Tahapan-tahapan dalam manajemen kurikulum dalam satuan pendidikan ........ 35

E. Perencanaan dalam manajemen kurikulum ................................................... 43

F. Analisis dan identifikasi sumber daya yang dibutuhkan di satuan pendidikan .. 51

G. Efektifitas dalam implementasi manajemen kurikulum pada satuan pendidikan

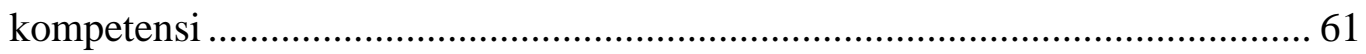

H. Evaluasi manajemen kurikulum pada satuan pendidikan ................................. 74

I. Tugas pokok dan fungsi manajemen dan personil satuan pendidikan dalam

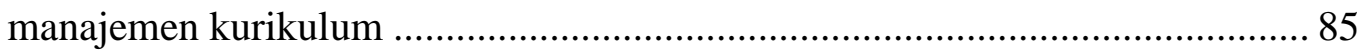

J. Inovasi dalam implementasi manajemen kurikulum ..................................... 102

K. Kompetensi dalam penyusunan jadwal di tingkat satuan pendidikan .............. 111

L. Model dan pengembangan organisasi kurikulum ....................................... 122

M. Peran dan aplikasi IT dalam manajemen kurikulum dan analisis kasus dalam

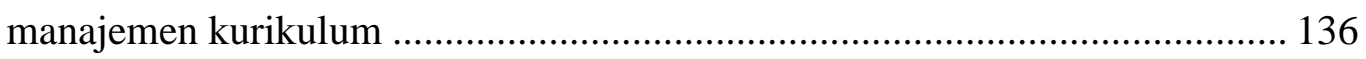

\section{DAFTAR PUSTAKA}




\section{BAB I \\ PENDAHULUAN}

\section{A. LATAR BELAKANG}

Manajemen tidak akan terlepas dari kegiatan pembelajaran karena manajemen tersebut merupakan usaha untuk mensukseskan suatu tujuan dalam pendidikan. Diperlukan adanya pengelolaan, penataan, dan pengaturan ataupun kegiatan yang sejenis yang masih berkaitan dengan lembaga pendidikan guna mengembangkan sumber daya manusia agar dapat memenuhi tujuan daripada pendidikan tersebut seoptimal mungkin.

Manajemen kurikulum adalah sebuah bentuk usaha atau upaya bersama untuk memperlancar pencapaian tujuan pengajaran khususnya usaha meningkatkan kualitas interaksi belajar mengajar. Dalam upaya - upaya tersebut diperlukan adanya evaluasi, perencanaan, dan pelaksanaan yang merupakan satuan rangkaian yang tidak dapat dipisahkan. Sedangkan manajemen pembelajaran ialah suatu sistem dengan komponen-komponen yang saling berkaitan. Komponen-komponen pembelajaran meliputi: peserta didik, guru, bahan ajar, kurikulum, sarana prasarana, serta strategi pembelajaran. Dengan demikian manajemen kurikulum dan pembelajaran saling berkaitan satu sama lain dalam suatu pendidikan, untuk mencapai tujuan yang diinginkan.

Manajemen kurikulum salah satu aspek yang berpengaruh terhadap keberhasilan pembelajaran dalam pendidikan nasional. Di samping itu, kurikulum merupakan suatu sistem program pembelajaran untuk mencapai tujuan institusional pada lembaga pendidikan, sehingga kurikulum memegang peranan penting dalam mewujudkan sekolah yang bermutu atau berkualitas. Untuk menunjang keberhasilan kurikulum, diperlukan upaya pemberdayaan bidang manajemen atau pengelolaan kurikulum. Pengelolaan kurikulum pada tingkat lembaga atau sekolah perlu di koordinasi oleh pihak pimpinan (manajer) dan pembantu pimpinan (manajer) yang dikembangkan secara integral dalam konteks 
Manajemen Berbasis Sekolah (MBS) dan Kurikulum Tingkat Satuan Pendidikan (KTSP) serta disesuaikan dengan visi dan misi lembaga pendidikan yang bersangkutan.

Berdasarkan hal tersebut, makalah ini ditulis untuk membantu mempersiapkan manajemen sekolah bermutu terutama berkenaan dengan manajemen kurikulum yang akan dilaksanakan pada tingkat satuan pendidikan di sekolah, baik itu dilakukan oleh para guru, komite sekolah, kepala sekolah, dan pihak pihak yang terkait dengan mengembangkan kurikulum pada tingkat satuan pendidikan.

\section{B. RUMUSALAH MASALAH}

Konsep keseluruhan manajemen kurikulum

C. TUJUAN

Mahasiswa memahami konsep keseluruhan manajemen kurikulum 


\section{BAB II}

\section{KONSEP MANAJEMEN KURIKULUM}

A. KOMPETENSI : Memahami, Mengembangkan potensi, Meningkatkan efektivitas, Mendesain kurikulum, Mengontrol implementasi kurikulum.

\section{B. TUJUAN}

Mahasiswa memahami Konsep Manajemen Kurikulum

\section{MATERI}

1. Pengertian manajemen kurikulum

Manajemen adalah proses bekerja sama antara individu dan kelompok serta sumber daya lainnya dalam mencapai tujuan organisasi adalah sebagai aktivitas majerial (Harsey, 1988: 4).

Kurikulum adalah seperangkat rencana dan pengaturan mengenai tujuan,isi dan bahan pelajaran serta bahan yang digunakan sebagai pedoman penyelenggaraan kegiatan pembelajaran untuk mencapai tujuan pendidikan tertentu (Rusman, 2009: 3).

Manajemen kurikulum adalah suatu sistem pengelolaan kurikulum yang kooperatif, komperhensif, sistemik dan sistematik dalam rangka mewujudkan ketercapaian tujuan kurikulum. Dalam pelaksanaannya, manajemen berbasis sekolah (MBS) dan kurikulum tingkat satuan pendidikan (KTSP). Oleh karena itu, otonomi yang diberikan pada lembaga pendidikan dalam mengelola kurikulum secara mandiri dengan memprioritaskan kebutuhan dan ketercapaian sasaran dalam visi dan misi lembaga pendidikan tidak mengabaikan kebijaksanaan nasional yang telah ditetapkan (Rusman, 2009: $3)$.

2. Ruang lingkup manajemen kurikulum

Manajemen kurikulum merupakan bagian integral dari kurikulum tingkat satuan pendidikan (KTSP) dan manajemen berbasis sekolah (MBS).Ruang lingkup manajemen kurikulum meliputi perencanaan, pengorganisasian, pelaksanaan dan evaluasi kurikulum. Pada tingkat satuan pendidikan kegiatan kurikulum lebih mengutamakan untuk merealisasikan dan merelevansikan 
antara kurikulum nasional (standar kompetensi/ kompetensi dasar) dengan kebutuhan daerah dan kondisi sekolah yang bersangkutan, sehingga kurikulum tersebut merupakan kurikulum yang integritas dengan peserta didik maupun dengan lingkungan sekolah (Rusman, 2009: 4).

\section{Prinsip Manajemen Kurikulum}

Terdapat 5 prinsip yang harus diperhatikan dalam melaksanakan manajemen kurikulum, yaitu:

a. Produktivitas, hasil yang akan diperoleh dalam kegiatan kurikulum merupakan aspek yang harus dipertimbangkan dalam manejemen kurikulum. Pertimbangan bagaimana agar peserta didik dapat mencapai hasil belajar sesuai dengan tujuan kurikulum harus menjadi sasaran dalam manajemen kurikulum.

b. Demokratisasi, pelaksanaan manajemen kurikulum harus berdasarkan demokrasi yang menempatkan pengelola, pelaksana dan subjek didik pada posisi yang seharusnya dalam melaksanakan tugas dengan penuh tanggung jawab untuk mencapai tujuan kurikulum.

c. Kooperatif, untuk memperoleh hasil yang diharapkan dalam kegiatan manajemen kurikulum perlu adanya kerja sama yang positif dari berbagai pihak yang terlibat.

d. Efektivitas dan efisiensi, rangkaian kegiatan manajemen kurikulum harus mempertimbangkan efektivitas dan efisiensi untuk mencapai tujuan kurikulum sehingga kegiatan manajemen kurikulum tersebut memberikan hasil yang berguna dengan biaya, tenaga, dan waktu yang relatif singkat.

e. Mengarahkan visi, misi dan tujuan yang ditetapkan dalam kurikulum, proses manajemen kurikulum harus dapat memperkuat dan mengarahkan visi,misi dan tujuan kurikulum.

Selain prinsip- prinsip tersebut juga perlu dipertimbangkan kebijaksanaan pemerintah maupun departemen pendidikan nasional, seperti USPN No.20 tahun 2003, kurikulum pola nasional pedoman penyelenggaraan program kebijaksanaan penerapan manajemen berbasis sekolah, kebijaksanaan penerapan kurikulum tingkat satuan pendidikan (KTSP), keputusan dan 
peraturan pemerintah yang berhubungan dengan lembaga pendidikan atau jenjang/jenis sekolah yang bersangkutan. Dalam proses pendidikan perlu dilaksanakan manajemen kurikulum agar perencanaan, pelaksanaan, dan evaluasi kurikulum berjalan lebih efektif, efisien dan optimal dalam memberdayakan berbagai sumber belajar, pengalaman belajar, maupun komponen kurikulum (Rusman, 2009: 4).

\section{Fungsi Manajemen Kurikulum}

a. Meningkatkan efisiensi pemanfaatan sumber daya kurikulum, pemberdayaan sumber maupun komponen kurikulum dapat ditingkatkan melalui pengelolaan yang terencana dan efektif.

b. Meningkatkan keadilan (equity) dan kesempatan pada siswa untuk mencapai hasil yang maksimal, kemampuan yang maksimal dapat dicapai peserta didik tidak hanya melalui kegiatan intrakulikuler, tetapi juga perlu melalui kegiatan ekstra dan kokurikuler yang dikelola secara integritas dalam mencapai tujuan kurikulum.

c. Meningkatkan relevansi dan efektivitas pembelajaran sesuai dengan kebutuhan peserta didik maupun lingkungan sekitar peserta didik, kurikulum yang dikelola secara efektif dapat memberikan kesempatan dan hasil yang relevan dengan kebutuhan peserta didik maupun lingkungan sekitar.

d. Meningkatkan efektivitas kinerja guru maupun aktivitas siswa dalam mencapai tujuan pembelajaran, pengelolaan kurikulum yang professional, efektif, dan terpadu dapat memberikan motivasi pada kinerja guru maupun aktivitas siswa dalam belajar.

e. Meningkatkan efisiensi dan efektivitas proses belajar mengajar, proses pembelajaran selalu dipantau dalam rangka melihat konsistensi antara desain yang telah direncanakan dengan pelaksanaan pembelajaran. Dengan demikian, ketidaksesuaian antara desain dengan implementasi dapat dihindarkan. Disamping itu, guru maupun siswa selalu termotivasi untuk melaksanakan pembelajaran yang efektif dan efisien karena adanya 
dukungan kondisi positif yang diciptakan dalam kegiatan pengelolaan kurikulum.

f. Meningkatkan partisipasi masyarakat untuk membantu mengembangkan kurikulum, kurikulum yang dikelola secara professional akan melibatkan masyarakat, khususnya dalam mengisi bahan ajar atau sumber belajar perlu disesuaikan dengan ciri khas dan kebutuhan pembangunan daerah setempat (Rusman, 2009: 5)

5. Bentuk-Bentuk kurikulum

a. Subject matter/ subject centered curriculum, yaitu kurikulum yang terdiri atas mata pelajaran yang terpisah-pisah. Meteri yang dipelajari oleh siswa telah disusun secara logis oleh para ahli bidang studi. Contohnya : Sejarah, Biologi

b. Broad field/ fused/correlated curriculum, yaitu kurikulum yang disusun dengan mengkorelasikan atau menggabungkan sejumlah mata pelajaran dalam satu kesatuan dengan demikian terjadi perkawinan antar mata pelajaran sejenis. Contohnya : Ipa,Ips,Matematika,Bahasa Indonesia dan Kesenian.

c. Integrated Curriculum, yaitu kurikulum yang diorganisasikan dalam bentuk unit-unit tanpa harus ada mata pelajaran atau bidang studi. Pembelajaran dilaksanakan dengan "unit taching" dan materinya menggunakan "unit lesson". Pelajaran disusun bersama guru dan murid, mengandung suatu masalah yang luas, menggunakan metode "problem solving", sesuai dengan minat dan perkembangan anak. Contohnya: Agama,Bahasa,Perhitungan.

d. Core curriculum, yaitu kurikulum inti yang diberikan kepada semua murid untuk mencapai keseluruhan program kurikulum secara utuh. Contohnya : Agama, Ppkn

6. Menurut Hamalik (2007: 5) Konsep kurikulum berkembang berjalan dengan perkembangan teori dan praktik pendidikan, juga bervariasi sesuai dengan aliran atau teori pendidikan yang dianut.

menyatakan bahwa terdapat tujuh pandangan mengenai kurikulum yaitu : 
a. Kurikulum sebagai suatu program kegiatan yang terencana

b. Kurikulum sebagai hasil belajar yang diharapkan

c. Kurikulum sebagai reproduksi kultural

d. Kurikulum sebagai kumpulan tugas dan diskrit

e. Kurikulum sebagai agenda rekonstruksi sosial

f. Kurikulum sebagai curere

g. Sudut pandang berbeda antara kurikulum lama dan kurikulum baru.

7. Menurut Nana (1997: 27) Ada tiga konsep tentang kurikulum

a. kurikulum sebagai suatu substansi, suatu kurikulum, dipandang orang sebagai suatu rencana kegiatan belajar bagi murid-murid di sekolah, atau sebagai suatu perangkat tujuan yang ingin dicapai. Suatu kurikulum juga dapat menunjuk kepada suatu dokumen yang berisi rumusan tentang tujuan,bahan ajar, kegiatan belajar-mengajar, jadwal, dan evaluasi. Suatu kurikulum juga dapat digambarkan sebagai dokumen tertulis sebagai hasil persetujuan bersama antara para penyusun kurikulum dan pemegang kebijaksanaan pendidikan dengan masyarakat. Suatu kurikulum juga dapat mencakup lingkup tertentu, suatu sekolah, suatu kabupaten, propinsi, ataupun seluruh negara.

b. kurikulum sebagai suatu sistem, yaitu sistem kurikulum. sistem kurikulum merupakan bagian dari sistem persekolahan, sistem pendidikan, bahkan sistem masyarakat. Suau sistem kurikulum mencakup struktur personalia, dan prosedur kerja bagaimana cara menyusun suatu kurikulum, melaksanakan, mengevaluasi, dan menyempurnakannya. Hasil dari suatu sistem kurikulum adalah tersusunnya suatu kurikulum, dan fungsi dari sistem kurikulum adalah bagaimana memelihara kurikulum agar tetap dinamis.

c. kurikulum sebagai suatu bidang studi yaitu bidang studi kurikulum. ini merupakan bidang kajian para ahli kurikulum dan ahli pendidikan dan pengajaran. Tujuan kurikulum sebagai bidang studi adalah mengembangkan ilmu tentang kurikulum dan sistem kurikulum. Mereka yang mendalami bidang kurikulum mempelajari konsep-konsep dasar 
tentang kurikulum. Melalui studi kepustakaan dan berbagaikegiatan penelitian dan percobaan, mereka menemukan hal-hal baru yang dapat memperkaya dan memperkuat bidang studi kurikulum.

\section{SOAL}

\section{PG}

1. manajemen adalah ilmu dan seni mengatur proses pemanfaatan sumber daya manusia dan sumber-sumber lainnya secara efektif dan efisien untuk mencapai tujuan tertentu. Merupakan definisi yang dikemukakan oleh ....
a. Rusman
b. Teguh
c. Hamalik
d. Malayu SP

2. suatu sistem pengelolaan kurikulum yang kooperatif, komperhensif, sistemik dan sistematik dalam rangka mewujudkan ketercapaian tujuan kurikulum. Merupakan definisi.......
a. Manajemen
b. Kurikulum
c. Manajemen kurikulum
d. Peraturan

3. Yang termasuk ruang lingkup manajemen kurikulum adalah......
a. Evaluasi Kurikulum
b. Peta Konsep
c. Rangkuman
d. Controlling

4. Yang termasuk prinsip manajemen kurikulum kecuali...
a. Produktivitas
b. Substansi
c. Demokratisasi
d. Kooperatif

5. Meningkatkan keadilan (equity) Termasuk dalam hal......

a. Prinsip manajemen kurikulum 

b. Pengertian manajemen kurikulum
c. Fungsi manajemen kurikulum
d. Bentuk manajemen kurikulum

6. Sebutkan bentuk-bentuk manajemen kurikulum....
a. Produktivitas, Demokratisasi, Kooperatif
b. Pengertian, Ruang lingkup, Tugas
c. Perencanaan, Pengorganisasian, Pengawasan
d. subject centered curriculum, Integrated Curriculum, Core curriculum

7. Apa yang dimaksud dengan Integrated Curriculum.....
a. kurikulum yang terdiri atas mata pelajaran yang terpisah-pisah.
b. kurikulum yang diorganisasikan dalam bentuk unit-unit tanpa harus ada mata pelajaran atau bidang studi.
c. kurikulum inti yang diberikan kepada semua murid untuk mencapai keseluruhan program kurikulum secara utuh.
d. kurikulum yang disusun dengan mengkorelasikan atau menggabungkan sejumlah mata pelajaran

8. sebutkan contoh dari bentuk kurikulum Core curriculum...
a. Agama, Ppkn
b. Bahasa, Matematika, Ipa
c. Ipa,Ips,Sejarah
d. Sejarah, Perhitungan, Bahasa

9. - Kurikulum sebagai suatu program kegiatan yang terencana

- Kurikulum sebagai hasil belajar yang diharapkan

- Kurikulum sebagai reproduksi kultural

- Kurikulum sebagai kumpulan tugas dan diskrit

- Kurikulum sebagai agenda rekonstruksi sosial

- Kurikulum sebagai curere

- Sudut pandang berbeda antara kurikulum lama dan kurikulum baru.

Pandangan kurikulum diatas dikemukakan oleh...
a. Nana
b. Rusman 

c. Hamalik
d. Teguh

10. Sebutkan yang termasuk konsep manajemen kurikulum, kecuali
a. Substansi
b. Sistem
c. Bidang studi
d. Administrasi

\section{ESSAI}

1. Jelaskan yang dimaksud dengan kurikulum sebagai substansi !

2. Sebutkan dan berikan contoh bentuk-bentuk kurikulum !

3. Apa yang dimaksud dengan manajemen kurikulum ?

4. Siapakah yang berpendapat manajemen adalah ilmu dan seni mengatur proses pemanfaatan sumber daya manusia dan sumber-sumber lainnya secara efektif dan efisien untuk mencapai tujuan tertentu?

5. Sebutkan prinsip manajemen kurikulum

\section{KUNCI JAWABAN}

\section{PG}

1. D

2. $\mathrm{C}$

3. A

4. B

5. $\mathrm{C}$

6. D

7. $\mathrm{B}$

8. A

9. $\mathrm{C}$

10. D

\section{ESSAI}


1. kurikulum sebagai suatu substansi, suatu kurikulum, dipandang orang sebagai suatu rencana kegiatan belajar bagi murid-murid di sekolah, atau sebagai suatu perangkat tujuan yang ingin dicapai. Suatu kurikulum juga dapat menunjuk kepada suatu dokumen yang berisi rumusan tentang tujuan,bahan ajar, kegiatan belajar-mengajar, jadwal, dan evaluasi. Suatu kurikulum juga dapat digambarkan sebagai dokumen tertulis sebagai hasil persetujuan bersama antara para penyusun kurikulum dan pemegang kebijaksanaan pendidikan dengan masyarakat. Suatu kurikulum juga dapat mencakup lingkup tertentu, suatu sekolah, suatu kabupaten, propinsi, ataupun seluruh negara.

2. Bentuk- bentuk Manajemen Kurikulum
a. subject centered curriculum, Contohnya : Sejarah, Biologi
b. correlated curriculum, Contohnya : Ipa,Ips,Matematika,Bahasa Indonesia dan Kesenian.
c. Integrated Curriculum, Contohnya: Agama,Bahasa,Perhitungan.
d. Core curriculum, Contohnya : Agama, Ppkn

3. Manajemen kurikulum adalah suatu sistem pengelolaan kurikulum yang kooperatif, komperhensif, sistemik dan sistematik dalam rangka mewujudkan ketercapaian tujuan kurikulum.

4. Malayu S.P Hasibuan (1995) dalam bukunya “ manajemen sumber daya “

5. Prinsip Manajemen Kurikulum
a. Produktivitas,
b. Demokratisasi
c. Kooperatif
d. Efektivitas dan efisiensi
e. Mengarahkan visi, misi dan tujuan yang ditetapkan 


\section{BAB III}

\section{RUANG LINGKUP MANAJEMEN KURIKULUM LEMBAGA PENDIDIKAN}

\section{A. KOMPETENSI}

Ruang Lingkup Manajemen Kurikulum Lembaga Pendidika

\section{B. TUJUAN}

Mahasiswa memahami ruang lingkup manajemen kurikulum lembaga pendidikan

\section{MATERI}

Manajemen kurikulum merupakan bagian integral dari kurikulum tingkat satuan pendidikan dan manajemen berbasis sekolah. Lingkup manajemen kurikulum adalah perencanaan, pengorganisasian, dan pengevaluasian. Menurut Rusman (2011), manajemen kurikulum merupakan bagian integral dari kurikulum tingkat satuan pendidikan (KTSP) dan manajemen berbasis sekolah (MBS).

Rusman, Manajemen kurikulum (Yogjakarta: Deepublish,2011), hlm. 77

1. Kurikulum tingkat satuan pendidikan (KTSP)

KTSP lebih mengutamakan untuk merealisasikan dan merelevasikan antara kurikulum nasional (standar kompetensi/kompetensi dasar) dengan kebutuhan daerah dan kondisi sekolah yang bersangkutan, sehingga kurikulum tersebut merupakan kurikulum tersebut merupakan kurikulum yang integritas dengan peserta didik maupun lingkungan dimana sekolah itu berada. Rusma (2011) mengemukakan bahwa dalam KTSP dikembangkan berdasarkan prinsipprinsip sebagai :

a. Berpusat pada potensi, perkembangan kebutuhan, dan kepentingan peserta didik dan lingkungannya.

b. Beragam dan terpadu

c. Tanggapan terhadap perkembangan ilmu pengetahuan, teknologi dan seni

d. Relevan dengan kebutuhan kehidupan

e. Menyeluruh dan berkesinambungan

Rusman, Mengemukaan prinsip-prinsip KTSP (Yogyakarta:Deepublish,2011), hlm. 77 
Dalam konteks kurikulum tingkat satuan pendidkan (KTSP) dijelaskan secara operasional oleh Lestari (2006) bahwa siklus manajemen pengembangan kurikulum di sekolah terdiri dari empat tahap yaitu:

1) Tahapan perencanaan, meliputi langkah-langkah:

a) Analisi kebutuhan

b) Merumuskan dan menjawab pertanyaan filosofi

c) Menentukan desain kurikulum dan

d) Membuat rencana induk (master plan) berupa pengembangan, pelaksanaan dan penilaian

2) Tahap pengembangan, meliputi langkah-langkah:

a) Perumusan rasional atau dasar pemikiran

b) Perumusan visi, misi dan tujuan

c) Penentuan struktur dan isi program

d) Pemilihan dan pengorganisasian materi

e) Pengorganisasian kegiatan pembelajaran

f) Pemilihan sumber, alat dan sarana belajar dan

g) Penentuan cara mengukur hasil belajar

3) Tahap implementasi atau pelaksanaan, meliputi langkah-langkah:

a) Penyusunan rencana dan program pembelajaran (silabus dan rencana pelaksanaan pembelajaran)

b) Penjabaran materi (kedalaman dan keluasan)

c) Penentuan strategi dan metode pembelajaran

d) Penyediaan sumber, alat dan saran pembelajaran

e) Penentuan cara dan alat penilaian proses dan hasil belajar

f) Seting lingkungan pembelajaran (wahyudin, 2014:13)

4) Tahap evaluasi atau penilaian

KTSP terdiri dari tujuan pendidikan tingkat satuan pendidikan, struktur dan muatan kurikulum tingkat satuan pendidikan, klaender dan silabus. Penyusunan kurikulum dilakukan oleh satuan pendidikan dengan berdasarkan npada standar kompetensi lulusan, standar isi, 
standar kompetensi dan kompetensi dasar yang dikembangkan oleh Badan Standar Nasional Pendidikan (BSNP)

Lestari, Rena. Siklus manajemen (Yogyakarya:Deepublis,2006), hlm.78

Manajemen kurikulum adalah segenap proses usaha bersama untuk memperlancar pencapaian tujuan pengajaran dengan titik berat pada usaha, meningkatkan kualitas interaksi belajar mengajar. Kurikulum dalam arti sempit adalah jadwal pelajaran. Kurikulum dalam arti luas adalah semua pengalaman yang diberikan oleh lembaga pendidikan kepada anak didik selama mengikuti pendidikan. Dengan pengertian ini maka pengaturan halaman sekolah, penempatan keranjang sampah atau ketatnya disiplin sekolah dijalankan ikut termasuk dalam cakupan kurikulum karena semuanya itu akan menghasilkan suatu yang tercermin pada lulusan.

Pengembangan kurikulum berlandaskan manajemen, berarti melaksakan kegiatan

pengembangan kurikulum berdasarkan pola pikir manajemen, atau berdasarkan proses manajemen sesuai dengan fungsi-fungsi manajemen, yang terdiri dari :

1. Perencanaan kurikulum, yang dirancang berdasarkan analisis kebutuhan, menggunakan model tertentu dan mengacu pada suatu desain kurikulum yang efektif

2. Pengorganisasian kurikulum yang ditata baik secara struktural maupun secara fungsional

3. Implementasi yakni pelaksanaan kurikulum di lapangan

4. Ketenagaan dalam pengembangan kurikulum

5. Kontrol kurikulum yang mencakup evaluasi kurikulum

6. Mekanisme pengembangan kurikulum secara menyeluruh 
7. Segi manajemen dalam pelaksanaan kurikulum

Pengertian manajemen kurikulum

Kurikulum adalah seperangkat rencana dan pengaturan mengenai tujuan, isi, dan bahan pelajaran serta cara yang digumakan sebagai pedoman penyelenggaraan kegiatan pembelajaran untuk mencapai tujuan pendidikan tertentu. Menurut Saylor, Alexander, dan Lewis (1974) kurikulum merupakan segala upaya sekolah untuk mempengaruhi siswa agar dapat belajar, baik dalam ruangan kelas maupun diluar sekolah. Sementara itu, Harold B. Alberty (1965) memandang kurikulum sebagi semua kegiatan yang di berikan kepada siswa dibawah tanggung jawab sekolah. 
D. Latihan soal pilihan ganda dan essay

\section{Berikan tanda silang $(x)$ pada salah satu huruf $a, b, c$ atau d dengan jawaban yang tepat !}

1. Apa itu manajemen pendidikan ..........
a. Pengelolaan bidang pendidikan
b. Hasil bidang pendidikan
c. Kegiatan belajar mengajar
d. Kurikulum dalam bidang pendidikan

2. Manajemen kurikulum merupakan ..........
a. Seperangkat hasil dari bidang pendidikan
b. Seperangkat rencana dan pengaturan mengenai tujuan
c. Pengelolaan bidang pendidikan
d. Seperangkat kegiatan belajar mengajar

3. Ruang lingkup manajemen kurikulum, kecuali
a. Perencanaan
b. Pengorganisasian
c. Pengevaluasian
d. Keefektifan

4. (MBS) singkatan dari ..........
a. Manajemn berbasis sekolah
b. Manajemen budaya sekolah
c. Manajemen banyaknya sekolah
d. Melakukan bersama sekolah

5. (KTSP) singkatan dari ..........
a. Kurikulum tingkatan satuan pendidikan 

b. Kurikulum tingkat satu pendidikan
c. Kurikulum tingkat satuan pendidikan
d. Kurikulum tingkatan satu pendidikan

6. Dalam pengembanga kurikulum disekolah terdidri dari beberapa kilus manajemen pengembangan, terdiri dari berapa sikluskah pengembnagan kurikulum tersebut
a. 5
b. 6
c. 3
d. 4

7. (BSNP) singkatan dari
a. Badan satuan nasional
b. Badan satu nasional pendidikan
c. Badan standar nasional pendidikan
d. Badan standaran nasional pendidikan

8. Penyususnan rencana dan program pembelajaran meliputi ..........
a. Silabus dan rencana pelaksanaan pembelajaran
b. Silabus dan pelaksanaan pembelajaran
c. Pelaksanaan dan rencana
d. Perencanaan dalam pelaksanaan

9. Perumusan rasional adalah
a. Dasar program
b. Dasar pemikiran
c. Metode pembelajaran
d. Dasar dalam metode belajar

10. Perumusan visi, misi dan tujuan termasuk
a. Tahap implementasi
b. Tahap evaluasi
c. Tahap perencanaan
d. Tahap pengembangan 


\section{Jawablah pertanyaan-pertanyaan dibawah ini dengan tepat !}

1. Apa itu manajemen pendidikan, jelaskan ...........

2. Dalam tahapan implementasi atau pelaksanaan harus meliputi ...........

3. Kurikulum tingkat satuan pendidikan dapat termasuk tahapan ...........

4. Manajemen kurikulum dapat meluputi ..........

5. BNSP ( Badan Nasional Satuan Pendidikan ) sudah termasuk pada bagian .......

\section{Jawaban pilihan ganda !}

1. A

2. B

3. D

4. A

5. C

6. D

7. $\mathrm{C}$

8. A

9. B

10. D 


\section{Jawaban Essay !}

1. Manajemen pendidikan adalah alat untuk mencapai tujuan pendidikan melalui pengelolaan bidang-bidang pendidikan

2. Dalam implementasi pelaksanaan meliputi :penentuan, penjabaran, penyusunan rencana, penyediaan, penentuan, setting lingkungan.

3. Evaluasi atau penelitian

4. Perencanaan, pengorganisasian, dan pengevaluasian

5. Bagian integral dari kurikulum satuan pendidikan 


\section{BAB IV}

\section{MASALAH-MASALAH DAN KENDALA DALAM IMPLEMENTASI KURIKULUM}

\section{A. TUJUAN}

Tujuan daripembuatan makalah ini tak lain adalah untuk memenuhi tugas mata kuliah "MANAJEMEN KURIKULUM" dan memahami masalah-masalah serta kendala dalam implementasi kurikulum

\section{B. MATERI}

\section{BERBAGAI MASALAH KURIKULUM}

\section{MASALAH UMUM}

Berbagai masalah yang termasuk dalam masalah umum dapat di kelompokkan menjadi delapan kelompok, yaitu bidang cakupan ( scope ), relevensi, keseimbangan, integrasi, sekuensi, kontinuitas, artikulasi, dan kemampuan transfer ( transfrability )

1. bidang cakupan ( scope )

scope atau bidang cakup dapat didefinisikan sebagai "luas" kurikulum, yang di dalamnya mencakup berbagai topik, pengalaman belajar, aktivitas, pengorganisasian elemen-elemen, serta hubungan pengintegrasian "elemenelemen," serta hubungan pegintegrasian dan pengorganisasian berbagai elemen tersebut, yang harus di berikan kepada siswa di sekolah. J.G Saiylor dan W.M. Alexsander sebagai mana di kutip oliva ( 1992 ), berpendapat bahwa :

" by scope is meant the breadth, variety, and types of education experiences that are to be prouided pupils as they progress through the programs".

Untuk menentukan scope tersebut, para pengembang kurikulum dihadapkan pada sejumlah permasalahan berikut.

1. pengorganisasian berbagai elemen dan hubungan antar elemen tersebut 
menurut J.I.. Goodlad, elemen scope adalah sebagai "the actual focal poin for learning through which the school's objectives are to attained". Dari pengertian ini dapat di pahami bahwa unsur- unsur scope merupakan hal-hal pokok ( actual pointes ) yang harus di pelajari siswa di sekolah. Sehubungan dengan hal tersebut, maka tiyler menyarankan agar para pengembang kurikulum sebaiknya dapat mengorganisasikan hubungan antar elemen atau unsure scope tersebut, yang berupa konsep ilmu pengetahuan, dan berbagai keterampilan yang harus di berikan pada siswa. Dewasa ini masalah yang di hadapi adalah tidak terbatasnya konsep, pengetahuan dan keterampilan tersebut

2. pesatnya perkembangan IPTEK

sebagai ujung tombak dari implementasi, kurikulum sudah sewajarnya guru terus mencermati keterbatasan materi pelajaran. Ini di karenakan dewasa ini ilmu pengetahuan dan teknologi cenderung terus berkembang dan meningkat sedemikian pesatnya berkaitan dengan masalah ini A.J. Lewis ( Oliva. 1992 ) mengatakan bahwa :

"if the information continuous at the present pace, by the time child botn today graduates from college the amount of information in the world will have increased 32 times, and 97 percent of everiyting known in the world will have been learned since the child was born "

Dari kutipan di atas dapat di mengerti bahwa ketika anak yang di lahirkan saat ini menamatkan bangku kuliah, maka dunia informasi yang akan di hadapi nanti sudah berkembang empat kali lipat. Ketika anak tersebut berumur 50 tahun, dunia informasi menjadi berkembang 32 kali lipat. Padahal, 97 persen pengetahuan yang ada di dunia ini di peroleh anak semenjak ia di lahirkan. Hal ini jelas merupakan masalah tersendiri yang di hadapi para pengembang kurikulum dalam penentuan scope kurikulum yang akan di kembangkan sangat jelas, bahwa scope kurikulum harus di kaitkan 
pada keadaan atau kondisi yang di alami siswa saat ini dengan prediksi berbagai kemajuan IPTEK di masa depan.

3. Penetapan prosedur tujuan

Caswel dan Campbell ( Oliva 1992 ) mengingatkan bahwa prosedur tujuan bukan hanya menyangkut pengalaman belajar, topik maupun organisasi dan hubungan antar elemen tetapi juga menyangkut lima tahapan berikut.

a. penetapan tujuan yang inklusif

b. tujuan umum tersebut harus di rumuskan lagi ke dalam sejumlah pernyataan tujuan umum yang lebih " kecil “

c. sejumlah pernyataan tersebut di terjemahkan ke dalam tujuan institutional ;

d. selanjutnya, tujuan institutional tersebut di uraikan ke dalam tujuan permata pelajaran ( bidang setudy ) dan

e. masing- masing tujuan permata pelajaran atau bidang study tersebut harus di uraikan ke dalam tujuan pembelajaran umum, yang selanjutnya di jabarkan lagi menjadi tujuan pembelajaran khusus perpokok bahasan, dengan ketentuan bahwa pernyataan tersebut dapat di ukur.

4. pengambilan keputusan

masalah lain yang di hadapi dalam penentuan scope kurikulum adalah pengambilan keputusan tentang jadi atau tidaknya scope tersebut di tetapkan sebagai cakupan sebuah kurikulum. Dalam pengambilan keputusan ( decision making ) tersebut, oliva mengajukan sebuah pertanyaan yang harus di pertimbangkan yaitu :

a. apa yang sebenarnya di perlukan agar siswa dapat sukses di dalam masyarakat

b. kebutuhan-kebutuhan apa yang di butuhkan oleh daerah, bangsa, dan dunia, dan 
c. hal- hal esensial apa yang harus di ajarkan

2. Relevansi

Relevansi atau kesesuaian merupakan masalah lain yang cukup esensial dan harus mendapatkan perhatian dalam pengembangan kurikulum, berikut adalah salah satu inter pretensi tentang relevansi yang di kemukakan oleh B.O. Smith ( Oliva, 1992 ):

The teacher is constantly asked: why should I learn that? What is the use of studying history? Why should I be rekuired to take biology? The intent of thes kuentions is to ask what use one can make of them in everyday activitiyes, only general answers are possible. We can and do talk about the relevance of subjeck mater to the decisions and activitiyes that pupils will have to make we know, among other things, they must :

a. Choose and follow a vocation

b. Exercise the tasks of citizenship

c. Engaged in personal relationship and

d. Take party in culture-caryying activities

The question of the relevance pointes to the question of what is most assuredly useful."

Dari kutipan di atas dapat di ketahui bahwa pengertian relevansi memang mengandung dan sekaligus mengundang banyak penafsiran. Ini di karenakan kata relevansi itu sendiri harus dikaitkan dengan masalah dunia kerja (vocation), kependudukan (citizenship), hubungan antarpribadi ( personal relationship ), dan berbagai aktivitas masyarakat lainnya yang menyangkut budaya, social, politik, dan sebagainya. Meskipun demikian, jelas terlihat bahwa masalah relevansi berkembang menurut kegunaan dan kebermaknaan satu kurikulum bagi orang dan masyarakat dan bangsa, bahkan bagi komunitas bangsa di dunia pada umumnya. 


\section{KESEIMBANGAN}

Dalam sulitnya mendefinisikan kata balance atau keseimbangan, oliva menunjukan beberapa variyabel yang harus di pertimbangkan seperti:

a. kurikulum yang berpusat pada siswa ( child centered curriculum ) dan kurikulum berpusat pada pelajaran ( subject centered curriculum );

b. kebutuhan siswa dan kebutuhan masyarakat ( needs as sessments )

c. pendidikan umum dan pendidikan khusus

d. luas dan dalamnya kurikulum

e. tiga domain penting pendidikan ( kognitif, efektif, dan psikomotorik )

f. pendidikan individual dan pendidikan masyarakat

g. inovasi dan tradisi

h. logis dan psikologis

i. kebutuhan yang diharapkan dan tidak di harapkan siswa

j. kebutuhan akademis yang diharapkan

k. metode, pengalaman, dan strategi

1. cepatnya perubahan dan pergantian waktu atau masa

m. dunia kerja dan permainan

n. sekolah dan masyarakat sebagai sumber daya dalam pendidikan

o. disiplin kelembagaan

p. tujuan tujuan kelembagaan dan

q. disiplin ilmu

dikarenakan begitu banyaknya variabel yang menyangkut keseimbangan dalam pengembangan kurikulum tersebut, maka sudah dapat di pstikan bahwa hal ini juga telah menjadi suatu masalah yang tidak dapat di abaikan begitu saja oleh para pengembang kurikulum. Sebaliknya, justru merupakan masalah yang harus mendapatkan perhatian yang cukup maksimal. 


\section{Integrasi}

Para pengembang kurikulum harus perduli terhadap masalah pengintegrasian mata pelajaran. Pengintegrasian berarti memadukan mengembangkan dan menyatuksn antardisiplin ilmu. Tyler ( oliva, 1992 ) mendefinisikan integrasi sebagai berikut :

"the horizontal relationship of curriculum experiences"....

" the organization of these experiences should be such that they help the student increasingly to get a unified view and to unity his behavior in relation to the elements dealts with".

Sehubungan dengan pendapat yang di kemukakan oleh tyler tersebut, taba juga menyatakan bahwa:

"it is recognized that learning is more effective when facts and principles from one field can be related to another, especially when applying this knowledge".

Meskipun demikian, lain halnya dengan penentuan scope dan sekuens yang bersipat keharusan, pengintegrasian ini bersifat optional ( pilihan ) dan kadang kadang bahkan controversial. Apakah kurikulum berkeinginan untuk mengintegrasikan pelajaran atau tidak, bergantung pada filosopi pengetahuannya.

Bagaimanapun juga, kurikulum adalah suatu hal yang terintegrasi. Kadar dan tingkat keintegrasian lebih di tentukan oleh dasar filosofis pengembang kurikulum, dibandingkan berdasarkan data empiris. Namun karena tidak semua guru berpandangan demikian, dengan alasan bahwa terdapat beberapa pelajaran yang harus di ajarkan terpisahkan ( separated )makan kalangan progresif menawarkan agar para guru, sebagai pengembang kurikulum, memosisikan dirinya pada continnum (rangkaian).

Korelasi mata pelajaran ( correlation of subject matter ) yaitu hubungan di antara mata pelajaran yang masih ada unsur keterpisahannya seperti dalam 
pengajaran sejarah dan sastra, matematika dan sains, serta seni, musik dan sastra. Korelasi akan menjadi integrasi jika identitas masing-masing di lepaskan .

Terdapat dua pandangan integrasi seperti yang di tawarkan oleh taba. Pertama seperti yang di bahas sekarang ini terdapat hubungan horizontal antar pelajar. Dalam hal ini, taba ( oliva 1992) juga menyatakan bahwa :

Integration is also defined as something that happens to an individual ".

Adapun pandanga kedua mengatakan bahwa :

" the problem then, is that of developing ways of helping individual in this process of creating a unity of knowledge. This interpretation of integration throws the emphasis from integrating subjects to locating the integrative threads".

Para perencana kurikulum harus memutuskan model pengorganisasian yang akan di gunakan, apakah korelasi atau integrasi mata pelajaran. Hal yang perlu diperhatikan adalah bahwa scope, relevansi, keseimbangan, dan integrasi merupakan suatu rangkayan yang erat sekali kaitannya satu sama lain.

5. Sekuens ( sequence)

Sekuens ( sequence ) berarti susunan atau urutan pengelompokan kegiatan atau langkah-langkah yang dilakukan dalam perencanaan kurikulum. Bila scope mengacu pada "apa", maka sekuens lebih mengacu pada " kapan " dan "di mana" pokok-pokok bahasan tersebut di tempatkan dan di laksanakan berikut adalah langkah-langkah sekuens.

a. mulai dari yang paling sederhana menuju yang komples

b. menuruti alur kronologis

c. balikan dari alur kronologis

d. mulai dari keadaan geografis yang dekat sampai ke yang jauh

e. dari jauh menuju dekat 
f. dari konkret ke abstrak

g. dari umum menuju khusus dan

h. dari kehusus menuju umum

Donald E. Orlosky dan B. Othanel Smith ( Oliva, 1992 ) mengemukakan bahwa terdapat tiga konsep sekuens yaitu sekuens menurut kebutuhan, sekuens macro, dan sekuens mikro. Dalam proses sekuens, para pengembang kurikulum harus memperhatikan tingkat kedewasaan, latar belakang pengalaman, tingkat kematangan dan ketertarikan atau minat siswa, serta tingkat kegunaan dan kesukaran materi pelajaran.

\section{Kontinuitas}

Kontinuitas merupakan pengulangan terencana tentang isi (content) untuk mecapai keberhasilan. Tyler mendeskripsikan kontinuitas sebagai pengulangan vertical dari elemen atau unsur kurikulum.

Pada dasarnya, prinsip kontiuitas menyerupai dengan apa yang di sebut " spiral curriculum ", yaitu pengenalan konsep keterampilan, dan pengetahuan secara berulang, dalam permasalahan kontinuitas ini, dibutuhkan tingkat keahlian yang tinggi dari perencana kurikulum, baik menyangkut pengetahuan terhadap materi pelajaran (subject matter), maupun pengetahuan tentang siswanya. Kontinuitas bukanlah semata-mata pengulangan isi (content) pelajaran, melainkan merupakan pengulangan yang kompleks dan canggih ( shopisticated) dalam upaya peningkatan hasil belajar.

\section{Artikulasi}

Artikulasi di artikan sebagai pertautan antar kelompok elemen atau unsur lintas tingkatan sekolah. Contohnya dapat di lihat antar SD dan SLTP, SLTP dan SMA, serta antara SMA dan Perguruan tinggi (PT), yang juga tak lepas dalam dimensi sekuens seperti halnya kontinuitas.

Oliver ( Oliva, 1992 ) menjelaskan pengertian artikulasi sebagi “ artikulasi horizontal " atau " korelasi”, sedangkan kontinuitas sebagai " artikulasi vertical 
“. Dari pengertian ini dapat diketahui bahwa antara sekuens, kontinuitas, dan artikulasi terdapat kaitan satu dengan yang lainnya, sekuens merupakan pengaturan unit-unit dan materi pelajaran secara logis dan kronologis menurut unit, lembaga dan tingkatannya. Kontinuitas merupakan rencana introduksi dan reintroduksi unit-unit materi yang sama di berbagai tingkatan dalam uapaya meningkatkan pemahaman yang kompleks dan komprehensif. Adapun artikulasi merupakan rencana sekuens unit-unit materi pelajaran tersebut secara lintas tingkatan.

\section{Kemampuan Transfer ( Transfrability )}

Segala hal yang di berikan sekolah pada hakikatnya merupakan " proses pentransferan nilai “, maksudnya apapun yang di pelajari di sekolah seharusnya harus dapat diaplikasikan di luar sekolah, saat siswa sudah menamatkan pendidikannya. Dengan demikian, proses pendidikan di sekolah harus dapat memperkaya kehidupan siswa.

Para ahli pensisikan seperti Thorndike, Daniel dan L. N. Tanner serta Taba menyepakati bahwa jika guru hendak mentransfer nilai-nilai tersebut, maka terlebih dahulu harus diperhatikan prinsip-prinsip umum dari proses transfer yaitu:

a. Transfer merupakan " hati nurani " pendidikan

b. proses transfer memungkinkan untuk dilakukan

c. proses transfer di mulai dari situasi yang lebih dekat ke situasi luar kelas yang lebih jauh dan luas

d. hasil transfer akan lebih bermakna (meaningful) jika guru membantu siswa dalam menderivasi, generalisasi, serta menetapkan generalisasi tersebut dan

e. secara umum, dapat di katakan bahwa ketika siswa memperoleh pengetahuan bagi dirinya, proses transfer tersebut telah berhasil . 
Transferability merupakan prinsip dari pengajaran dan sekaligus juga perinsip dari kurikulum. Pada saat membicarakan metode mengajar transferability, berarti kita memasukan wilayah proses pengajaran. Pada saat menganalisis hal yang di transferkan, maka kita telah memasuki wilayah kurikulum, oleh karena itu para pengembang kurikulum harus menentukan tujuan, menyeleksi isi atau materi, dan memilih setrategi pengajaran yang mengarah pada pendaya gunaan proses transfer secara maksimal, selanjutnya, dalam perencanaan evaluasi kurikulum juga harus di masukkan ukuran tingkatan transfer dari berbagai segmen dalam kurikulum.

\section{MASALAH KHUSUS}

Dalam kaitannya dengan pengembangan kurikulum, beberapa masalah berikut perlu di pahami secara seksama.

1. berbagai masalah yang berhubungan dengan tujuan dan hasil-hasil kurikulum yang di harapkan oleh sekolah seperti :

a. untuk siapa kurikulum itu di sediakan

b. apakah kurikulum tersebut bermaksud mendidik siswa agar mampu mengendalikan diri, atau agar mereka mampu mengikuti perubahan social

c. apakah kurikulum bersifat mendoktrinasi sesuatu,

d. apakah kurikulum bermaksud mempersiapkan siswa bagi masa depannya, atau untuk memenuhi berbagai kebutuhan yang dirasakan sekarang ini.

e. Apakah kurikulum memberikan pelayanan terhadap masyarakat atau perorangan

f. Apakah kurikulum berkenaan dengan permasalahan yang controversial

g. Apakah kurikulum disesuaikan dengan minat dan kebutuhan perorangan atau umum 
h. Apakah kurikulum berkenaan dengan pendidikan umum atau dengan pendidikan khusus

i. Apakah kurikulum dikatakan dengan usaha pencapaian tujuan-tujuan pendidikan, dan

j. Apakah tujuan-tujuan tersebut diperbaiki guna mencapai hasil pendidikan yang lebih baik.

2. berbagai masalah yang berhubungan dengan isi dan organisasi kurikulum, yang terdiri atas:

a. ukuran yang di gunakan dalam memilih bahan dan pengalaman-pengalaman kurikuler

b. apakah kurikulum disususn berdasarkan mata pelajaran atau pengusahaan adanya korelasi

c. perbedaan-perbedaan yang terdapat dalam kurikulum tersebut

d. jenis-jenis kegiatan dan pengalaman yang terdapat dalam kurikuler.

e. Jenis kurikulum yang digunakan.

f. Pengalaman-pengalaman yang diwajibkan dan yang bersifat pilihan

g. Apakah dalam kurikulum terdapat pelajaran-pelajaran khusus

h. Berbagai pelajaran yang diperlukan untuk kenakikan kelas, dan

i. Cara perbaikan seleksi dan organisasi bahan-bahan pelajaran dan pengalaman.

3. masalah yang berhubungan dengan proses penyusunan dan revisi kurikulum, seperti :

a. cara pengadaan artikulasi dan korelasi,

b. awal penyusunan dan perevisian kurikulum

c. sumber-sumber informasi yang dapat di manfaatkan untuk penyusunan kurikulum.

e. Pihak yang dapat ikut berpartisipasi dalam perubahan dan penyusunan kurikulum 
f. Pihak yang akan memberikan latihan dalam pengelolaan kurikulum dan dalam bentuk pelaksanaan latihan tersebut

g. Langkah-langkah yang akan di lakukan dalam menadakan perubahan (revisi) kurikulum secara menyeluruh, dan

h. Cara perbaikan peruses penyusunan kurikulum

\section{Peran Guru dalam Pengembangan Kurikulum}

Dalam studi tentang ilmu mengajar dan kurikulum, pembahasan mengenai permasalahan yang dialami guru senantiasa mendapat tempat tersendiri. Ini di karenakan guru mengemban peran yang sangat penting dalam keberhasilan proses pendidikan. Bahkan berdasarkan pandangan yang ada sekarang ini, betapapun bagus dan indahnya kurikulum keberhasilan kurikulum tersebut pada akhirnya bergantung pada masing masing guru.

Oleh karena itu, masalah profesi keguruan, tantangan-tantangan yang kemungkinan besar dihadapi oleh guru-guru professional, peranan guru dalam pengembangan kurikulum dan masalah pendidikan guru, juga perlu mendapat pembahasan tersendiri.

Pengembangan kurikulum melibatkan banyak pihak, terutama guru yang bertugas di kelas. Setiap guru mengemban tanggungjawab secara aktif dalam perencanaan, pelaksanaan, penilaian, pengadmimistrasian, dan perubahan kurikulum sejauh mana keterlibatan guru akan turut menentukan keberhasilan pengajaran di sekolah.

Sejauh manakah peran guru dalam perencanaan kurikulum? Kurikulum di susun oleh suatu lembaga tertentu (di Indonesia, kurikulum disusun oleh BP3K), yang umumnya dirancang oleh ahli kurikulum dengan bantuan ahli pisikologi belajar dan ahli bidang studi. Para guru bidang studi yang dianggap telah memiliki pandangan yang luas biasanya di ikutsertakan dalam 
penyususnan kurikulum tersebut. Kepada mereka, dimintakan saran-saran sesuai dengan pengalaman mereka dalam melaksanakan kurikulum di sekolah

\section{FAKTOR-FAKTOR YANG MEMENGARUHI IMPLEMENTASI KURIKULUM}

Implementasi Kurikulum dipengaruhi oleh tiga faktor, yaitu :

1. Karakteristik kurikulum, yang mencakup ruang lingkup bagan ajar, tuan, fungsi, sifat dan sebagainya.

2. Strategi implementasi, yaitu strategi yang digunakan dalam implementasi kurikulum, seperti diskusi profesi, seminar, penataan, lokakarya penyediaan buku kurikulum dan berbagai kegiatan lain yang dapat mendorong penggunaan kurikulum di lapangan.

3. Karakteristik pengguna kerikulum, yang melupyti pengetahuan, keterampilan, serta nilai dan sikap guru terhadap kurikulum dalam pembelajaran

Dalam pengimplementasian kurikulum diperkukan komitmen semua pihak yang terlibat dan didukung oleh kamampuan professional serti gugu sebagai salah satu implementator kerikulum.

Marsh (1980) mengemukakan tiga factor yang memengaruhi implementasi kurikulum, yaitu dukungan kepala sekolah, dukungan rekan sejawat guru, dan dukungan internal di dalam kelas. Dari berbagai factor tersebut, guru merupakan factor penentu utama. Dengan kata lain, keberhasilan implementasi kurikulum di sekolah sangat ditentukan oleh faktor guru, karena bagaimanapun baiknya sarana pendidikan, jika implementasi kerikulum tidak akan berhasil. 


\section{SOAL/LATIHAN}

Essai

1. Uraikan apa yang dimaksud dengan sdope dan sequence, dan mengapa keduanya menjadi masalah penting dalam penyusunan kerukulum?

2. Sebutkan dan jelaskan faktor-faktor yang memengaruhi implementasi kurikulum?

3. Apakah guru-guru diikut sertakan dalam perbaikan kurikulum di sekolahnya? Dalam system pendidikan kita dewasa ini, apakah hal tersebut dimungkinkan? Tunjukannlah bukti-bukti nyata yang mendukudungnya!

4. Jelaskan apa yang di maksud dengan Kurikulun?

5. Jelaskan apa yang dimaksud Implementasi Kurikulum?

PG (Pilihan ganda)

1. Strategi yang digunakan dalam implementasi kurikulum, seperti diskusi profesi, semionar, penataan dan lokakarya penyediaan buku kurikulum dan berbagai kegiatan lain yang dapat mendorong penggunaan kurikulum di lapangan disebut...
a. Strategi Implementasi
b. Implementasi Kurikulun
c. Kurikulum
d. Implementasi

2. Pengulangan terencana tentang isi (content) untuk mecapai keberhasilan disebut...
a. Kontinuitas
b. Artikulasi
c. System Kurikulum
d. Implementsi Kurikulum

3. Susunan atau urutan pengelompokan kegiatan atau langkah-langkah yang dilakukan dalam perencanaan kurikulum disebut... 

e. Sekuens (Sequence)
b. Artikulasi
c. Kontinuitas
d. System Kurikulum

4. Prinsip dari pengajaran dan sekaligus juga perinsip dari kurikulum disebut...
a. Transferability
b. Kontinuitas
c. Artikulasi
d. Kurikulum 


\section{BAB V}

\section{TAHAPAN-TAHAPAN DALAM MANAJEMEN KURIKULUM DALAM SATUAN PENDIDIKAN}

\section{A. KOMPETENSI}

1. Menjelaskan pengertian Manajemen kurikulum.

2. Menjelaskan Faktor-Faktor yang mempengaruhi Implementasi Kurikulum.

3. Menjelaskan Prinsip-Prinsip Implementasi Kurikulum.

4. Menjelaskan Tahap-tahap Implementasi Kurikulum.

5. Menjelaskan Perencanaan Kurikulum.

\section{B. TUJUAN PENULISAN}

Mahasiswa mampu memahami tentang Tahapan-Tahapan Dalam Manajemen Kurikulum Dalam Suatu Pendidikan.

\section{MATERI}

\section{PENGERTIAN MANAJEMEN KURIKULUM}

Manajemen Menurut Stoner dalam buku manajemen perubahan merupakan serangkaian kegiatan merencanakan, mengorganisasikan, dan mengendalikan segala upaya dalam mengatur dan mendayagunakan sumberdaya manusia, sarana, dan prasarana secara efisien dan efektif untuk mencapai tujuan organisasi yang telah ditetapkan. (saefullah, 2016:31)

Kurikulum dalam bahasa yunani berasal dari kata Curir yang artinya pelajar dan Curere yang artibya tempat berpacu. Curere dalam kamus websters jika menjadi kata benda berarti lari cepat, pacuan, balapan, uber kereta, berkuda, perjalanan, suatu pengalaman tanpa henti, dan lapangan perlombaan. (Triwiyanto, 2015:22).

Menurut Undang-undang Nomor 20 Tahun2003, Kurikulum adalah sperangkat rencana dan pengaturan mengetahui tujuan, isi, dan bahan pembelajaran, serta cara yang digunakan sebagai pedoman penyelenggaraan kegiatan pembelajaran untuk mencapai tujuan pendidikan tertentu. Tujuan 
tersebut meliputi tujuan pendidikan nasional, kesesuian dengan kekhasan, kondisi dan potensi daerah, satuan pendidikan, dan peserta didik (Triwiyanto, 2015:22).

Dediknas (2004) menyatakan bahwa kurikulum merupakan seperangkat rencana dan pengaturan tentang kompetensi yang dibakukan dan cara pencapaiannya disesuaikan dengan keadaan dan kemampuan. Kurikulum dilaksanakan dalam rangka membantu peserta didik mengembangkan berbagai potensi baik psikis dan fisik yang meliputi moral dan nilai-nilai agama, sosialemosional, kognitif, bahasa, fisik/motorik, kemandirian dan seni. (Triwiyanto, 2015:22).

Jadi yang dimaksud manajemen Kurikulum disini ialah serangkaian kegiatan yang dilakukan untuk merencanakan segala sesuatu dalam mengatur rencana mengenai tujuan, isi dan bahan pembelajaran serta cara yang digunakan sebagai pedoman dalam penyelenggaraan kegiatan pembelajaran untuk mencapai tujuan pendidikan.

2. FAKTOR-FAKTOR YANG MEMPENGARUHI IMPLEMENTASI KURIKULUM

Implementasi kurikulum di pengaruhi oleh tiga faktor, yaitu :

a. Karakteristik kurikulum, yang mencakup ruang lingkup bahan ajar, tujuan, fungsi, sifat, dan sebagainya.

b. Strategi implementasi, yaitu strategi yang di gunakan dalam implementasi kurikulum, seperti diskusi, seminar, penataan, lokakarya penyediaan buku kurikulum, dan berbagai kegiatan lain yang dapat mendorong penggunaan kurikulum di lapangan.

c. Karakteristik penggunaan kurikum, yang meliputi pengetauan, keterampilan, serta nilai dan sikap guru terhadap kurikulum dalam pembelajaran.

Dalam mengimplementasikan kurikulum di perlukan komitmen semua pihak yang terlibat, dan di dukung oleh kemampuan professional seperti guru sebagai salah satu implementatorkurikulum.

Marsh (1980) mengemukakan tiga faktor yang memengaruhi implementasi kurikulum, yaitu dukungankepala sekolah dukungan rekan 
sejawat guru,dan dukungan internal di dalam kelas. Dari berbagai faktor tersebut, guru mendapatkan faktor penentu utama. Dengan kata lain, keberhasilan implementasi kurikulum di sekolah sangat di tentukan oleh faktor guru, karena bagaimanapun baiknya sarana pendidikan, jika guru tidak melaksanakan tugasnya dengan baik, maka implementasi kurikulum tidak akan berhasil. (Hamalik,2007: 239).

\section{PRINSIP-PRINSIP IMPLEMENTASI KURIKULUM}

a. Perolehan kesempatan yang sama

Prinsip ini mengutamaka penyediaan tempat yang memberdayakan semua peserta didik secara demokratis dan keadilan untuk memperoleh pengetahuan, keterampilan dan sikap. Seluruh peserta didik berasal dari beberapa kelompok, termasuk kelompok yang kurang beruntung secara ekonomi dan sosialyang memerlukan bantuan khusus.

b. Berpusat pada anak

Upaya untuk memandirikan pesera didik untuk belajar, bekerjasama dan menilai dirisendiri sangat di utamakan agar peserta didik mampu membangun kemauan, pemahaman dan pengetahuan.

c. Pendekatan dan kemitraan

Seluruh pengalaman belajar di rancang secara bersinambungan, mulai dari taman kanak-kanak hingga kelas 1 sampai XII. Pendekatan yang di gunakan dalam pengorganisasian pengalaman belajar focus pada kebutuhan peserta didik yang bervariasi dan mengintegrasikan berbagai di siplin ilmu. Keberhasilan pencapaian pengalaman belajar menuntut kemitraan dan tanggung jawab bersama peserta didik, guru, sekolah, perguruan tinggi, dunia kerja dan industri, orang tua dan masyarakat.

d. Kesatuan dalam kebijakan dan keagamaan dalam pelaksanaan

Standar kompetensi di susun oleh pusat dengan cara pelaksanaannyadi sesuaikan dengan kebutuhan kemampuan masing-masing daerah atau sekolah (Hamalik,2007: 239)

\section{TAHAP-TAHAP IMPLEMENTASI KURIKULUM}


Implementasi kurikulum mencakup tiga kegiatan pokok, yaitu : pengembangan program, pelaksanaan pembelajaran, dan evaluasi.

a. Pengembangan program mencakup program tahunan, semester atau catatatan harian, mingguan, dan bulanan. Selain itu, ada juga peogram bimbingan dan konseling atau program remedial.

b. Pelaksanaan pembelajaran. Pada hakikatnya, pembelajaran adalah proses interaksi antara peserta didik dengan lingkungannya, sehingga terjadi perubahan perilaku arah yang lebih baik. Dalam pembelajaran, tugas guru yang paling utama adalah mengondisikan lingkungan agar menunjang terjadinya perubahan prilaku bagi peserta didik tersebut.

c. Evaluasi proses yang di laksanakan sepanjang proses pelaksanaan kurikulum atau semester serta penilaiaan akhir formatif dan sumilatif mencakup penilaiaan keseluruhan secara utuh untuk keperluan evaluasi pelaksaan kurikulum. (Hamalik,2007: 239)

\section{PERENCANAAN KURIKULUM}

Perencanaan kurikulum adalah perencaan kesempatan-kesempatan belajar yang di maksud untuk membina siswa kearah perubahan perubahan tingkah laku yang di inginkan dan menilai sampai mana perubahan-perubahan telah terjadi pada diri siswa. Di dalam perencanaan kurikulum minimal ada lima hal yang mempengaruhi perencanaan dan pembuatan keputusan, yaitu filosopis, konten/materi, manajemen pembelajaran, pelatihan guru, dan sistem pembelajaran.

Kurikulum adalah semua pengalaman yang telah di rencanakan untuk mempersiapkan siswa mencapai tujuan pendidikan. Perencanaan kurikulum mencakup pengumpulan, pembentukan, sistensis, menyeleleksi informasi yang relevan dari berbagai sumber. Kemudian informasi yang dapat di gunakan untuk mendesain pengalaman belajar sehingga siswa dapat memperoleh tujuan kurikulum yang di harapkan. (Rusman, 2009 : 21) 
D. SOAL

PG

1. Kurikulum berasal dari bahasa yunani dari kata?
a. Curere
c. Damsar
b. Curir
d. James

2. Menurut undang-undang nomer 20 tahun 2003 kurikulum adalah?
a. Sebagai reproduksi kultural
b. Sebagai agenda rekonstrasi sosial
c. Perangkat rencana dan pengaturan mengenai tujuan, isi, dan bahan pelajaran.
d. Sebagai hasil belajar yang di harapkan

3. Implementasi kurikulum di pengaruhi oleh tiga faktor yaitu?
a. Karakteristik kurikulum, strategi implementasi, karakteristik pengguna kurikulum
b. Pelaksaan kurikulum, sistem penyampaian, tujuan pendidikan
c. Sesuai dengan pandangan, kegiatan dan pengalaman
d. komprehensif, dokumen tertulis, pikiran pihak pendidik

4. Karakteristik penggunaan kurikulum adalah.....
a. Keterampilan, pengetahuan, serta nilai dan sikap guru terhadap kurikulum dalam pembelajaran
b. Pandangan komprehensif terhadap setiap kegiatan yang di rencanakan
c. Menyampaikan mata pelajaran
d. Sesuai dengan kegiatan dan pengalaman

5. Jelaskan kegiatan pokok pelaksanaan pembelajaran?
a. Progragram harian, bulanan, dan tahunan
b. Konseling atau program remedial
c. Semester serta penilaian akhir
d. Pada hakekatnya, pembelajaran adalah proses interaksi antara peserta didik dengan lingkungannya.

6. Evaluasi adalah.......
a. Sistem penyampaian yang di pergunakan oleh guru
b. Pembentukan pribadi anak dan belajar cara hidup masyarakat 
c. Proses yang di laksanakan sepanjang proses pelaksanaan kurikulum

d. Sesuai dengan pandangan masyarakat

7. Pinsip-prinsip implementasi kurikulum, terdapat beberapa prinsip yang menunjang tercapainya keberhasilan, yaitu?

a. Proleh kesempatan yang sama, berpusat pada anak, pendekatan dan kemitraan, kesatuan dalam kebijakan dan keagamaan dalam pelaksanaan

b. Sebagai hasilinteraksi dengan lingkungan

c. Kompetensi dasar

d. Tujuan pembelajaran

8. Pengembangan program mencakup program......
a. Penilaian
b. Pelaksanaan kurikulum
c. Harian, bulanan, tahunan
d. Penyampaian materi pokok maupun materi standar

9. Karakteristik kurikulum ruang lingkup......
a. Penilaian hasil belajar
b. Bahan ajar, tujuan, fungsi sifat, dan sebagainya
c. Sumber belajar
d. Rombongan belajar

10. Marsh (1980) mengemukakan tiga faktor yang mempengaruhi implementasi kurikulum kurikulum yaitu?
a. Dukungan kepala sekolah, dukungan rekan sejawat guru,dan dukungan internal di dalam kelas.
b. Buku teks pembelajaran
c. Pengawasan proses pembelajaran
d. Aktifitas pembelajaran

\section{ESAI}

1. Jelaskan pengerian manajemen kurikulum?

2. Sebutkan faktor-faktor yang mempengaruhi implementasi kurikulum?

3. Sebutkan prinsip-prinsip implementasi kurikulum

4. Jelaskan perencanaan kurikulum? 
5. Marsh (1980) mengemukakan tiga faktor yang mempengaruhi implementasi kurikulum, sebutkan satu persatu? 


\section{JAWABAN}

PG

1. $\mathrm{B}$

2. $\mathrm{C}$

3. $\mathrm{A}$

4. $\mathrm{A}$

5. D

6. $\mathrm{C}$

7. A

8. C

9. B

10. A

\section{ESAI}

1. Kurikulum dalam bahasa yunani berasal dari kata Curir yang artinya pelajar dan Curere yang artibya tempat berpacu. Curere dalam kamus websters jika menjadi kata benda berarti lari cepat, pacuan, balapan, uber kereta, berkuda, perjalanan, suatu pengalaman tanpa henti, dan lapangan perlombaan.

2. Faktor-faktor yang mempengaruhi Implementasi Kurikulum dibagi menjadi tiga, yaitu :

a. Karakteristik kurikulum, yang mencakup ruang lingkup bahan ajar, tujuan, fungsi, sifat, dan sebagainya.

b. Strategi implementasi, yaitu strategi yang di gunakan dalam implementasi kurikulum, seperti diskusi, seminar, penataan, lokakarya penyediaan buku kurikulum, dan berbagai kegiatan lain yang dapat mendorong penggunaan kurikulum di lapangan.

c. Karakteristik penggunaan kurikum, yang meliputi pengetauan, keterampilan, serta nilai dan sikap guru terhadap kurikulum dalam pembelajaran.

3. Terdapat Empat Implementasi Kurikulum, yaitu :

a. Perolehan kesempatan yang sama 

b. Berpusat pada anak
c. Pendekatan dan kemitraan
d. Kesatuan dalam kebijakan dan keagamaan dalam pelaksanaan

4. Perencanaan kurikulum adalah perencaan kesempatan-kesempatan belajar yang di maksud untuk membina siswa kea rah perubahan perubahan tingkah laku yang di inginkan dan menilai sampai mana perubahan-perubahan telah terjadi pada diri siswa.

5. Marsh (1980) mengemukakan tiga faktor yang memengaruhi implementasi kurikulum, yaitu dukungankepala sekolah dukungan rekan sejawat guru,dan dukungan internal di dalam kelas. 


\section{BAB VI}

\section{PERENCANAAN DALAM MANAJEMEN KURIKULUM}

\section{A. TUJUAN PEMBELAJARAN: MAHASISWA MEMAHAMI (PERENCANAAN DALAM MANAJEMEN KURIKULUM) \\ B. MATERI:}

1. Pengembangan Kurikulum

2. Pengertian Perencanaan Kurikulum

3. Tujuan Perencanaan Kurikulum

4. Landasan Perencanaan Kurikulum

\section{Pengembangan Kurikulim}

Rusman (2011: 21) mengatakan bahwa perencanaan kurikulum sangat tergantung pada pengembangan kurikulum dan tujuan kurikulum yang akan menjadi penghubung teori-teori pendidikan yang akan digunakan.

Kurikulum merupakan komponen pendidikan yang semestinya dinamis dan berkembang terus-menerus. Pengembangan kurikulum berkaitan dengan kegiatan kegiatan yanng menghasilkan produk baru, selama kegiatan tersebut, penilaian dan penyempurnaan terhadap produk baru dilakukan. Soetopo dan W. Soemanto (1991) menyebutkan tiga landasan pengembangan kurikulum sebagai berikut.

a. Landasan filosofis. Apa yang diyakini seseorang sebagai suatu kebenaran merupakan sesuatu yang penting dalam proses pendidikan karena tujuan pendidikan yang terpenting adalah penanaman nilai-nilai. Taba (1962) menyebutkan tiga fungsi pendidikan, yaitu pendidikan/sekolah berfungsi memelihara dan menyampaikan warisan budaya, sebagai alat transformasi (mengubah) budaya, dan sebagai perkembangan individu.

b. Landasan sosial budaya. Perkembangan masyarakat memerlukan kajian mendalam untuk menentukan kurikulum, bukan berarti semua harus masuk dalam kurikulum, tetapi perlu seleksi apa yang patut dan tidak patut untuk disampaikan kepada peserta didik. 
c. Landasan psikologi. Psikologi berkenaan dengan perilaku manusia. Penerapan dalam pengembangan kurikulum berkaitan dengan psikologi belajar (teori belajar pembelajaran).

Pengembangan kurikulum menunjukan suatu kegiatan menghasilkan suatu alat atau cara baru, namun penilaian dan penyempurnaan terhadap alat atau cara tersebut tetap dilakukan. Ruang lingkup pengembangan kurikulum meliputi penyusunan kurikulum, pelaksanaan kurikulum di sekolah, evaluasi kurikulum (metode pembelajaran, pengembangan alat pembelajaran, dan media), dan penyempurnaan kurikulum dari hasil evaluasi.

Idi (2011: 205) menegaaskan bahwa hal ini dilakukan agar semua jam dan aktivitas pengajaran yang dilaksanakan oleh pendidik mupun peserta didik dapat betul-betul terarah pada tercapainya tujuan pendidikan yang telah ditetapkan.

Depdiknas (2008: 258) menyarankan untuk melakukan pengembangan kurikulum dan pembelajaran perlu mengikuti prinsip-prinsip pengembangan. Prinsip-prinsip pengembangan kurikulum dan pembelajaran antara lain:

a) Harus mencapai tujuan falsafah pendidikan sekolah dan nasional.

b) Dikembangkan pada satuan pendidikan dengan mengacu pada standar yang ditetapkan,

c) Perlu dikembangkan dari tingkat "akar rumput" dengan melibatkan konstribusi orang tua dan masyarakat.

d) Perlu memberikan peluang memenuhi kebutuhan peserta didik untuk memperoleh pelayanaan pendidikan sesuai dengan bakat, minat, dan kemampuannya.

e) Perlu mempertimbangkan budaya, kebiasaan, dan tradisi lokal, serta perlu menyediakan pengalaman pendidikan praktis.

Selain prinsip-prinsip diatas, harus diperhatikan pula bahwa kurikulum merupakan sebuah sistem. Sistem aadalah sekelompok atau seperangkat objek/bagian/komponen yang saling bergantung dan berhubungan satu sama lain, yang dapat menyelesaikan seperangkat tujuan yang telah ditetapkan. Kurikulum sebagai objek pandang sistem terdiri atas komponen satu dengan lainnya yang saling berhubungan. 
Taba (1962) menyebutkan komponen dalam sistem kurikulum, yaitu komponen tujuan (umun dan khusus), seleksi dan organisasi bahan, corak atau pola pembelajaran, dan program evaluasi terhadap hasil pembelajaran. Sementara itu, Sixten Marklund dalam Taba (1962) menyebutkan bahwa komponen dalam sistem kurikulum adalah komponen tujuan, bimbingan, bahan, metode pembelajaran, sarana, evaluasi, dan administrasi.

\section{Pengertian perencanaan kurikulum}

Perencanaan merupakan salah satu fungsi dari manajemen pendidikan, selain pengorganisasiannya dan evaluasi.

Usman (2010: 66) menyatakan bahwa perencanaan adalah kegiatan yang dilakukan dimasa yang akan datang untuk mencapai tujuan.

Perencanaan pendidikan adalah proses menetapkan keputusan yang berkaitan dengan tujuan-tujuan yang akan dicapai, sumber-sumber yang akan diberdayakan, dan teknik/metode yang dipilih secara tepata untuk melaksanakan tindakan selama kurun waktu tertentu agar penyelenggaraan sistem pendidikan dapat dilaksanakan secara efektif, efisien, dan bermutu (Engkoswara dan A. Komariah, 2010: 132). enurut Oemar Hamalik (2007: 152) perencanaan kurikulum adalah suatu proses sosial yang kompleks yang menuntut berbagai jenis dan tingkat pembuatan keputusan. Perencanaan kurikulum ini berfungsi sebagai pedoman atau alat manajemen yang berisi petunjuk tentang jenis dan sumber individu yang yang diperlukan, media pembelajaran yang digunakan, tindakan-tindakan yang perlu dilakukan, sumber biaya, tenaga, dan sarana yang diperlukan, sistem monitoring dan evaluasi, peran unsur-unsur ketenagaan untuk mencapai tujuan manajemen lembaga pendidikan. Di samping itu, perencanaan kurikulum juga berfungsi sebagai pendorong untuk melaksanakan sistem pendidikan sehingga mencapai hasil yang optimal.

\section{Tujuan Perencanaan Kurikulum}

Secara umum tujuan perencanaan menurut Usman (2010: 85) antara lain:

a. Sebagai standar pengawas, yaitu mencocokan pelaksanaan dengan perencanaanya.

b. Mengetahui kapan pelaksanaan dan selesainya kegiatan 
c. Mengetahui siapa saja yang terlibat (struktur organisasi), baik kualifikasi maupun kuantitas.

d. Mendapatkan kegiatan yang sistematis termasuk biaya dan kualitas pekerjaan.

e. Meminimalkan kegiatan-kegiatan yang tidak produktif, serta menghemat biaya, tenaga, dan waktu.

f. Memberikan gambaran yang menyeluruh mengenai kegiatan pekerjaan.

g. Menyerasikan dan memadukan beberapa sub kegiatan.Mendeteksi hambatan kesulitan yang bakal ditemui dan mengarahkan paada pencapaian tujuan.

\section{Landasan Perencanaan Kurikulum}

Perencanaan kurikulum pendidikan harus mengasimilasi dan mengorganisasi informasi dan data secara intensif yang berhubungan dengan pengembangan program lembaga atau sekolah. Informasi dan data yang menjadi area utama adalah sebagai berikut:

a. Kekuatan sosial

Kekuatan sosial merujuk pada penyesuaian perencanaan kurikulum dengan perubahan dan dinamika sosial yang terjadi dimasyarakat. Seperti, sistem politik, ekonomi, sosial, dan budaya

b. Perlakuan pengetahuan

Perlakuan pengetahuan merujuk pada pertumbuhan dan perkembangan pengetahuan, serta perilaku individu belajar aktif untuk mengumpulkan dan mengolah informasi, mencari fakta dan data, berusaha belajar tentang sikaf, emosi, perasaan terhadap pembelajaran, proses informasi, memanipulasi, menyimpan, dan mengambil kembali informasi tersebut untuk dikembangkan dan digunakan dalam kegiatan merancang kurikulum yang disesuaikan dengan perkembangan ilmu.

c. Pertumbuhan dan perkembangan manusia

Pertumbuhan dan perkembangan manusia merujuk pada informasi yang berhubungan dengan perkembangan manusia. Data-data ini penting seperti, kegiatan sekolah yang selalu menyediakan untuk pengembangan program sekolah baru, lebih awal anak belajar pendidikan khusus, pendidikan sekolah 
alternatif, dan pendidikan ekselerasi. Umumnya penting untuk dipahami tentang pola-pola dari pertumbuhan dan perkembangan karena para guru dituntut untuk merencanakan kurikulum atau program pembelajaran yang berkenaan dengan kebutuhan dan perkembangan siswa.

\section{SOAL}

Berilah tanda silang ( $x$ ) pada huruf $a, b$, c, atau d dengan jawaban yang benar!

1. Perencanaan kurikulum berkaitan dengan fungsi dan proses manajemen kurikulum. Fungsi atau proses tersebut meliputi .....
a. Perencanaan, pelaksanaan, dan evaluasi kurikulum.
b. Pengarahan dan pengawasan kurikulum.
c. Perencanaan kurikulum
d. Evaluasi kurikulum

2. Fungsi atau proses manajemen kurikulum tersebut berkaitan dengan .....
a. Pengembangan kurikulum
c. Landasan kurikulum
b. Perencanaan kurikulum
d. Perencanaan pembelajaran

3. Mensyaratkan adanya ruang gerak yang memberikan kebebasan dalam bertindak (tidak kaku)mencakup peserta didik dalam memilih program pendidikan dalam mengembangkan program pembelajaran. Hal ini merupakan prinsip dari .....
a. Efisien
c. kesinambung
b. Efektivitas
d. Prinsip fleksibilitas

4. Perencanaan kurikulum adalah suatu proses sosial yang kompleks yang menuntut berbagai jenis dan tingkat pembuatan keputusan. Hal ini merupaka pengertian perencanaan kurikulum menurut .....
a. Usman (2010: 66)
c. Herbert spencer (1879)
b. Rusman (2011:21)
d. Ocmar Hamalik (2007: 152)

5. Dalam perencanaan kurikulum minimal ada 5 hal yang memengaruhi perencanaan dan pembuatan keputusan, yaitu .... 
a. Filosopis, materi, manajemen pembelajaran,pelatihan guru, dan sistem pembelaAjaran.

b. Sumber biaya, tenaga, sarana, monitoring, dan evaluasi.

c. Kekuatan sosial, pengembangan masyarakat, kebutuhan, gaya belajar siswa, dan pelatihan.

d. Sarana dan prasarana, lokasi, tenaga, pelatihan guru dan evaluasi

6. Beberapa keputusan harus harus di buat ketika merencanakan kurikulum dan keputusan tersebut harus mengarah pada .....
a. Jumlah siswa
c. Pengembangan masyarakat
b. Gaya belajar siswa
d. Spesifikasi berdasarkan kriteria

7. Perencanaan kurikulum mencakup .....
a. Pengumpulan, pembentukan, sistensis, menyeleksi informasi yang relevan dari berbagai sumber.
b. Menyeleksi dan informasi dari satu pihak
c. Mencari informasi yang adaa
d. Pengumpulan dari berbagai pihak

8. Yang termasuk tujuan perencanaan kurikulum yaitu ....
a. Sebagai pedoman penyelenggaraan kegiatan pembelajaranu untuk mencapai tujuan pendidikan tertentu
b. Sebagai alat untuk belajar
c. Sebagai sumber daya
d. Sebagai alat transfortasi

9. Landasan perencanaan kurikulum untuk mengasimilasi dan mngorganisasi informasi dan data yang secara intensif yang berhubungan dengan pengembangan program lembaga atau sekolah. Informasi dan data yang menjadi area utama adalah ....
a. kekuatan intelektual dan kekuatan sosial
b. kekuatan sosial, perlakuan pengetahuan, pertumbuhan dan perkembangan manusia
c. pertumbuhan mausia
d. perkembangan manusia 
10. penyesuaian perencanaan kurikulum dengan perubahan dan dinamika sosial yang terjadi di masyarakat. Seperti, sistem politik, ekonomi, sosial, dan kebudayaan. Hal ini mepruakan pengertian dari ....
a. perlakuan pengetahuan
c. Kekuatan sosial
b. kekuatan sosial
d. pertumbuhan dan perkembangan

\section{Isilah titik-titik dibawah ini dengan jawaban yang tepat !}

1. Sebutkan prinsip-prinsip dalam pengembangan kurikulum!

2. Apa yang di maksud dengan kurikulum?

3. Apa pengertian perencanaan kurikulum?

4. Apa saja tujuan perencanaan kurikulum?

5. Apa perbedaan perencanaan kurikulum dan perencanaan pembelajaran ?

\section{KUNCI JAWABAN}

1. A

2. A

3. D

4. D

5. A

6. D

7. A

8. A

9. B

10. C

1. Prinsip-prinsip dalam pengembangan kurikulum, yaitu relevansi, efektivitas, efisiensi, kesinambungan, fleksibilitas, dan berorientasi tujuan.

2. Kurikulum merupakan seperangkat rencana dan pengaturan tentang kompetensi yang dibakukan dan cara penyampaiannya disesuaikan dengan keadaan dan kemampuan 
3. Pengertian perencanaan kurikulum adalah perencanaan kesempatan-kesempatan belajar yang dimaksudkan untuk membina siswa kearah perubahan tingkah laku yang diinginkan dan menilai sampai mana perubahan-perubahan telah terjadi pada diri siswa. Di dalam perencanaan kurikulum minimal ada lima hal yang memengaruhi perencanaan dan pembuatan keputusan, yaitu filosopis, konten/materi, manajemen pembelajaran, pelatihan guru, dan sistem pembelajaran.

4. tujuan perencanaan kurikulum, yaitu:

a. Sebagai pedoman penyelenggaraan kegiatan untuk mencapai tujuan pendidikan tertentu.

b. Standar pengawasan dalam pelaksanaan kurikulum, yaitu mencocokan pelaksanaan dengan perencanaannya.

c. Mengetahui suapa saja yang terlibat (struktur organisasinya),baik kualifikasinya maupun kuantitasnya untuk mencapai tujuan pendidikan

d. Merupakan gambaran kurikulumyang sistematis termasuk biaya dan kualitas pekerjaan.

e. Meminimalkan kegiatan-kegiatan yang tidak produktif, serta menghemat biaya, tenaga, dan waktu.

5. perencanaan kurikulum adalah perencanaan kesempatan-kesempatan belajar yang dimaksudkan untuk membina siswa kearah perubahan tingkah laku yang diinginkan dan menilai sampai mana perubahan-perubahan telah terjadi pada diri siswa.

Perencanaan pembelajaran adalah seperangkat rencana dan pengturan kegiatan pembelajaran, media pembelajaran, waktu, pengelolaan kelas, dan penilaian hasil belajar. 


\section{BAB VII}

\section{ANALISIS DAN IDENTIFIKASI SUMBER DAYA YANG DIBUTUHKAN DI SATUAN PENDIDIKAN}

\section{A. KOMPETENSI}

Pengenbangan Sumber daya (2006:84-85) di sekolah meliputi aspek-aspek SDM sekolah yang harus di kembangkan terdiri atas aspek pengembangan intake sekolah( calon peserta didik), tenaga pendidik, tenaga kependidikan dan tim pengembengansekolah.

\section{B. TUJUAN PEMBELAJARAN}

1. Menjelaskan pengertian sumber daya yang di butuhkan di satuan pendidikan

2. Menjelaskan sumber daya manusia (SDM) yang di butuhkan di satuan pendidikan

3. Menjelaskan sumber daya informasi yang di butuhkan di satuan pendidikan

4. Menjelaskan sumber daya fisik yang di butuhkan di satuan pendidikan

5. Menjelaskan sumber daya keuangan yang di butuhkan di satuan pendidikan

\section{MATERI PEMEBLAJARAN}

1. Pengertian Sumber Daya yang di butuhkan di Satuan Pendidikan

2. Sumber Daya Manusia (SDM) yang di butuhkan di Satuan Pendidikan
a. Kepala Sekolah
b. Pendidik (Guru)
c. Tenaga Kependidikan (TU)
d. Peserta didik
e. Karyawan

3. Sumber daya Informasi yang ada di saruan pendidikan
a. Manusia (ahli informasi dan pemakai);
b. Perangkat keras komputer;
c. Perangkat lunak komputer;
d. Basis data (data dan informasi); 
e. Jaringan (fasilitas)

4. Sumber daya fisik yang di butuhkan di satuan pendidikan

a. Sarana dan Prasarana

5. sumber daya keuangan yang di butuhkan di satuan pendidikan

1. Penjelasan Materi Pembelajaran

Sumber daya pendidikan adalah sumber daya manajemen yang terlibat dalam organisasi atau lembaga - lembaga termasuk lembaga pendidikan, antara lain : manusia, sarana dan prasarana, biaya, teknologi, dan informasi. Namun sumber daya yang paling penting dalam pendidikan adalah sumber daya manusia. Bagaimana manajer bakat kreativitas, dan semangat nya bagi organisasi. Karena itu tugas terpenting dari manajer adalah meyeleksi, menepatkan, melatih, dan mengembangkan sumber daya manusia.

Menurut shetty dan Vernon b. bucher (1985) (2008:62-63)sumber daya manusia harus terkandung aspek : kompetensi, keterampilan/ skill, kemampuan, sikap, perilaku, motivasi, dan komitmen.

Sumber daya merupakan input penting yang di perlukan untuk kalangan kalangan proses pendidikan di sekolah. Tanpa sumber daya uang memadai, proses pendidikan di sekolah tidak akan berlangsung secara memadai. dan pada akhirnya tidak tercapai.

\section{Kepala Sekolah}

Kepala sekolah (2006:18).adalah manajer yang menempati posisi yang telahdi tentukan di dalam organisasi. Kepala sekolah memiliki puncak yang memegang kunci keberhasilan dalam mencapai tujuan yang telah di tentukan. Kepala sekolah memiliki dua peran besar dalam melaksanakan tugasnya, yang pertama sebagai manajer dan yang kedua sebagai pemimpin. Kedua peran ini bersatu dan melekat pada kepala sekolah dan Bertanggung jawab atas keseluruhan kegiatan penyelenggaraan pendidikan di sekolahnya baik ke dalam maupun ke luar yakni dengan 
melaksanakan segala kebijaksanaan, peraturan dan ketentuanketentuan yang ditetapkan oleh lembaga yang lebih tinggi.

Kepemimpinan kepala sekolah dapat memberikan hasil yang baik, ada beberapa hal yang perlu dipahami dan dikuasai oleh kepala sekolah menyangkut manejemen pendidikan antara lain :

1. Kepala sekolah harus memiliki kemampuan kepemimpinan yang prima demi organisasi yang dipimpinnya.

Kepala sekolah perlu menciptakan rasa kekeluargaan di antaranya kepadasiswa, guru, orangtua,dan staf pendukung.

2. Kepala sekolah harus memiliki kemampuan yang baik dalam berkomunikas, yaitu kemampuan mengaitkan hubungan antara bahasa, pemahaman, dan tingkah laku.

3. Kepala sekolah harus memiliki kemampuan dalam menentukan kapanwaktu yang tepat untuk menerapkan berbagai gaya kepemimpinan, apakah akan menerapkan autokrasi atau partisipasi.

4. Kepala sekolah harus memiliki kesadaran diri berkenaan dengan kemampuan orang per orang, gaya alamiah, kekuatan, kelemahan, dobrakan pribadi bagaimana menyeimbnagkan semua hal tersebut sosok kepala sekolah yang berkarakter perlu dimiliki dan dipertahankan oleh seorang kepala sekolah agar bawahannya setia kepadanya.

Menurut Tjipto (2001:168), kepala sekolah harus menunjukan sikap-sikap kepribadian sebagai berikut :

a. Memiliki rasa tanggung jawab yang besar.

b. Memiliki disiplin pribadi yang tinggi.

c. Memiliki sifat yang jujur.

d. Memiliki kredibilitas yang tinggi. 
e. Wakil Kepala Sekolah, biasannya wakil Kepala Sekolah yaitu membantu kepala sekolah dalam urusan-urusan kurikulum, kesiswaan, sarana-prasarana serta humas.

\section{a. Pendidik (Guru)}

Kinerja sumber daya manusia (2005:9) adalah prestasi kerja atau hasil kerja (output) baik kualitas maupun kuantitas yang di capai sumber daya manusia persatuan periode waktu dalam melaksanakan tugas kerjanya sesuai dengan tanggung jawab yang diberikan kepada nya. Kinerja Guru merupakan kemampuan seseorang guru dalam melaksanakan tugas pembelajaran di sekolah/madrasah dan bertangung jawab atas peserta didik di bawah bimbinganya dengan meningkatkan prestasi belajar peserta didik.

Guru merupakan factor penentu yang dominan dalam proses pembelajaran peserta didik. Terkait dengan hal tersebut, guru harus memiliki peranan

a. Pendiagnosa Perilaku Peserta Didik

b. Penyusunan RPP

c. Penyebar informasi yang kominikator

Dalam UUGD ditentukan bahwa seorang guru harus:

1. Pendidik wajib memiliki kualifikasi akademik dan kompetensi pendidik sebagai agen pembelajaran.

2. Kulifikasi akademik diperoleh melalui pendidikan tinggi program sarjana (S1) atau diploma empat (D-IV) yang sesuai dengan tugas nya sebagai guru untuk guru dan S2 untuk dosen

3. Kompetensi profesi penddidik meliputi kompetensi pedagogic, kopentesi kepribadian, kopentensi professional, dan kompetensi social.

b. TU 
Adalah karyawan sekolah yang bertugas mengatur administrasi di lingkungan sekolah. Sehingga peranannya sangat penting dalam mengelola administrasi di sekolah, agar tertata dengan baik.

c. Peserta didik

Peserta didik bersetatus sebagai subjek didik. Pandangan modern cenderung menyebut demikian oleh karena peserta didik (tanpa pandangan usia) adalah subjek atau pribadi yang otonom, yang ingin diakui keberadaannya. Selaku pribadi yang memiliki ciri khas dan otonomi, ia ingin mengembangkan diri (mendidik diri) secara terus menerus guna memecahkan masalah-masalah hidup yang dijumpai sepanjang hidupnya.

Ciri khas peserta didik yang perlu dipahami oleh pendidik ialah:

a. Individu yang memiliki potensi fisik dan psikis yang khas, sehingga merupakan insan yang unik.

b. Individu yang sedang berkembang. Yang dimaksud dengan perkembangan di sini ialah perubahan yang terjadi dalam diri peserta didik secara wajar, baik ditujukan kepada diri sendiri maupun kearah penyesuaian dengan lingkungan.

c. Individu yang membutuhkan bimbingan individual dan perlakuan manusiawi.

Dalam proses perkembangan peserta didik membutuhkan bantuan dan bimbingan.

d. Karyawan

\section{Sumber Daya Informasi}

Terdiri dari :

1. Manusia (ahli informasi dan pemakai);

2. Perangkat keras komputer;

3. Perangkat lunak komputer;

4. Basis data (data dan informasi);

5. Jaringan (fasilitas) 
4. Sumber daya fisik yang di butuhkan di satuan pendidikan

Sarana dan Prasarana kegiatan yang mengatur untuk mempersiapkan segala peralatan/ material bagi terselenggaranya proses pendidikan di sekolah.

Kegiatan manajemen sarana dan prasarana meliputi :

1. Perencanaan kebutuhan

2. Pengadaan

3. Penyimpanan

4. Penginventarisasian

5. Pemeliharaan

6. Penghapusan

5. Sumber daya keuangan yang di butuhkan di satuan pendidikan

Keuangan atau pembiyaan pendidikan di lembaga - lembaga pendidikan menjadi factor esencial. Penangung jawab manajemen pembiayaan di sekolah adalah kepala sekolah dan guru yang betanggung

Soal pilihan ganda!

1. Dalam satuan pendidikan terdapat beberapa yang dibutuhkan oleh sekolah berikut....

a. kepala sekolah

b. guru

c. peserta didik

d. a,b,dan c benar

2. Guru sangat dibutuhkan disekolah karena...

a. untuk membuat siswa jadi rajin sekolh

b. untuk membuat siswa jadi pemalas

c. untuk membuat siswa meningkatkan prestasi belajar peserta didik. 
d. Membuat siswa menjadi bodoh

3. Apa tujuan manajemen peserta didik.....

a. Meningkatkan pengetahuan

b. Meningkatkan keterampilan

c. Meningkatkan pengetahuan dan keterampilan

d. Meningkatkan pengetahuan, keterampuilan, fisikomotor peserta didik

4. Menurut Tjipto (2001:168), kepala sekolah harus menunjukan sikap-sikap kepribadian sebagai berikut :

a. Memiliki rasa tanggung jawab yang besar.

b. Memiliki disiplin pribadi yang tinggi.

c. Memiliki sifat yang jujur dan Memiliki kredibilitas yang tinggi.

d. a,b,dan c benar

5. Menurut Tjipto (2001:168), kepala sekolah harus menunjukan sikap-sikap kepribadian sebagai berikut :

a. Memiliki rasa tanggung jawab yang besar.

b. Memiliki disiplin pribadi yang tinggi.

c. Memiliki sifat yang jujur.

d. Memiliki sifat memalaikan tugas nya

6. Sumber daya yang di butuhkan di satuan pendidikan.....
a. SDM
b. Informasi
c. Keuangan
d. a,b,dan c benar

7. Kelas, ruang guru, bangku meja, kantor, papan tulis, dll merupak number daya .....
a. Sarana dan prasarana
b. Keuangan
c. Informasi
d. Peserta didik

8. Apa saja tugas dan tanggung jawab guru sebagai manajer 

a. Menguasai program pengajaran
b. Meyusun program kegiatan mengajar
c. Menguasai program pengajaran dan kegiatan mengajar
d. b,dan c benar

9. manajer yang menempati posisi yang telah di tentukan di dalam organisasi di sekolah di sebut....

a. Tukang kebun

b. Kepala sekolah

c. Guru

d. Karyawan

10. Macam macam metode mengajar ialah, kecuali....
a. Metode proyek
b. Metode proyek dan Metode ekspremimen
c. Metode diskusi
d. Metode home schooling

esay

\begin{tabular}{|l|l|l|l|}
\hline NO & BUTIR PERTANYAAN & KUNCI JAWABAN & SKOR \\
\hline 1 & Apa itu sumber daya yang & Sumber daya pendidikan adalah & \\
di butuhkan di satuan? & $\begin{array}{l}\text { sumber daya manajemen yang } \\
\text { terlibat dalam organisasi atau } \\
\text { lembaga }- \text { lembaga termasuk } \\
\text { lembaga pendidikan, antara lain : } \\
\text { manusia, sarana dan prasarana, } \\
\text { biaya, teknologi, dan informasi. } \\
\text { Namun sumber daya yang paling } \\
\text { penting dalam pendidikan adalah } \\
\text { sumber daya manusia. }\end{array}$ & \\
& &
\end{tabular}




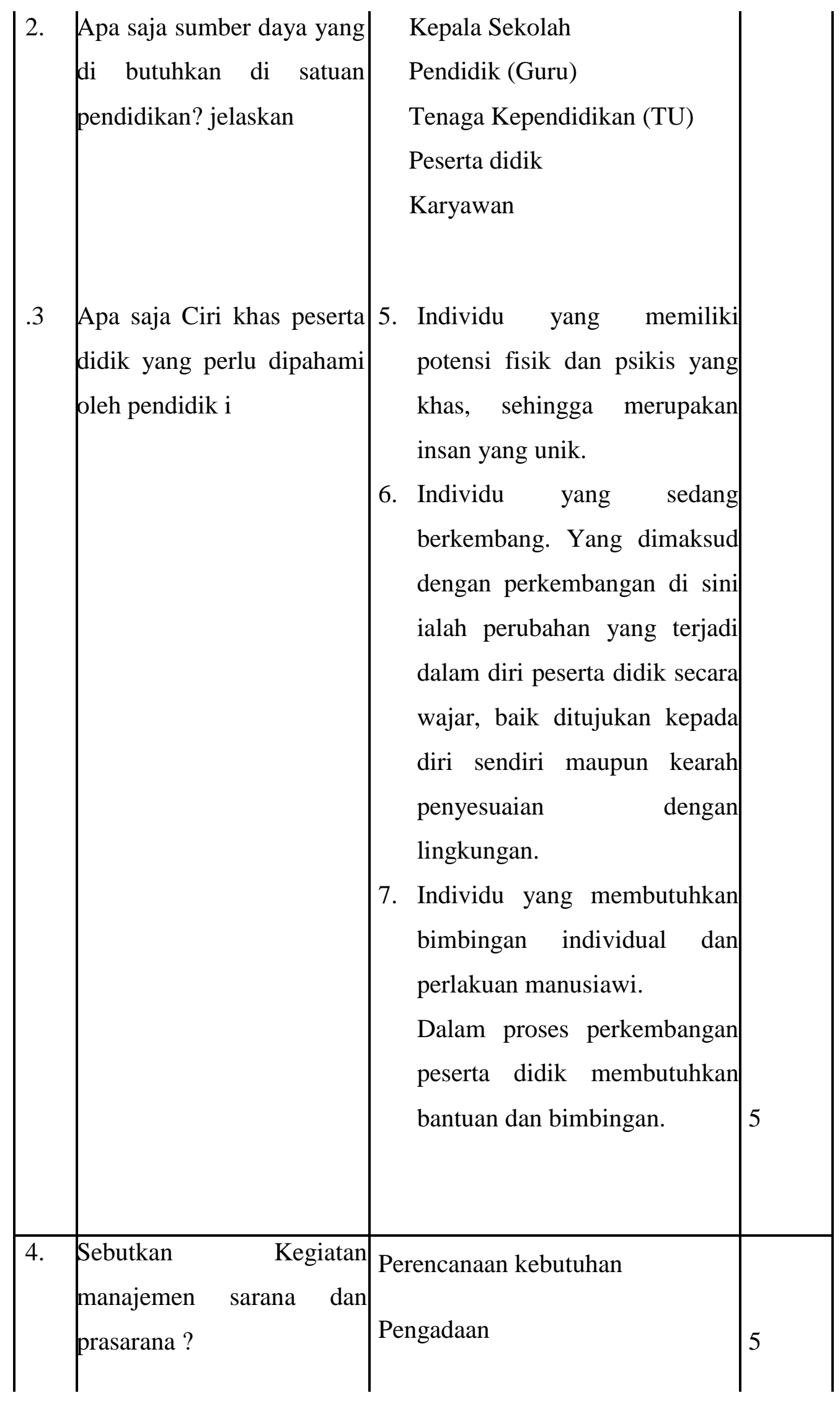




\begin{tabular}{|c|c|}
\hline Sumber Daya & $\begin{array}{l}\text { Penyimpanan } \\
\text { Penginventarisasian } \\
\text { Pemeliharaan } \\
\text { Penghapusan } \\
\text { 1. Manusia (ahli informasi dan } \\
\text { pemakai); } \\
\text { 2. Perangkat keras komputer; } \\
\text { 3. Perangkat lunak komputer; } \\
\text { 4. Basis data (data dan } \\
\text { informasi); } \\
\text { 5. Jaringan (fasilitas) }\end{array}$ \\
\hline
\end{tabular}




\title{
BAB VIII
}

\section{EFEKTIFITAS DALAM IMPLEMEMNTASI MANAJEMEN KURIKULUM PADA SATUAN PENDIDIKANEKOMPETENSI}

\begin{abstract}
A. KOMPETENSI: Dapat memahami efektifitas dalam implementasi manajemen kurikulum pada satuan pendidikan

\section{B. TUJUAN}

Mahasiswa memahami Efektifitas dalam implementasi manajemen kurikuluum pada satuan pendidikan.
\end{abstract}

\section{MATERI}

\section{Implementasi Kurikulum}

Implementasi kurikulum dapat diartikan sebagai aktivitas kurikulum tertulis (written curriculum) adalah bentuk pembelajaran. Berdasarkan hal tersebut maka dapat disimpulkan bahwa implementasi kurikulum adalah operasionalisasi konsep kurikulum yang masih bersifat potensial (tertulis) menjadi aktual dalam bentuk kegiatan pembelajaran.

Mars, dikutip oleh mulyasa (2006:247), mengemukakan tiga faktor yang mempengaruhi implementasi kurikulum, yaitu: dukungan kepala sekolah, dukungan rekan sejawat guru dan dukungan internal yang datang dari dalam diri guru sendiri. Dari berbagai faktor tersebut guru merupakan fakor penentu di samping fakor-fktor lain. Dengan kata lain, keberhasilan implementasi kurikulum sangat ditentukan oleh faktor guru, karna bagaimanapun baiknya sarana pendidikan apabila guru tidak melakukan tugas dengan baik, maka hasil implementasi kurikulum (pembelajaran) tidak akan memuaskan.

Menurut Kunandar (2007:236) dalam garis besar implemetasi kurikulum mencakup tiga kegiatan pokok, yaitu pengebangan program, pelaksanaan pembelajaran dan evaluasi. Pengembangan kurikulum adalah istilah yang komprehensif, di dalamnya mencakup perecanaan, penerapan dan evaluasi. perencanaan kurikulum adalah langkah awal membangun kurikulum ketika pekerja kurikulum membuat keputusan dan mengambil tindakan untuk menghasilkan perencanaan yang akan digunakan oleh guru dan pesaerta didik. 
Penerapan kurikulum atau bisa disebut juga implemetasi kurikulum berusaha mentransfer perencanaan kurikulum kedalam tindakan operasional. Evaluasi kurikulum merupakan tahap akhir dari pegembangan kurikulum untuk menentukan seberapa besar hasil-hasil pembelajaran, tingkat ketercapaian program-program yang telah direncanakan, dan hasil-hasil kurikulum itu sendiri. Dalam pengembangan kurikulum, tidak hanya melibatkan orang yang terkait langsung dengan dunia pedidikan saja namun di dalamnya melibatkan banyak orang, seperti: politikus, pengusaha, orang tua peserta didik, serta unsur-unsur masyarakat lainnya yang merasa berkepentingan dengan pendidikan.

Masih menurut Kunandar (2007:236-241) mengemukakan bahwa dalam peleksanaan kurikulum hal yang paling penting diperhatikan adalah potensi dan pengembangan peserta didik. Karena pesrta didik merupakan subyek dalam kegiatan pembelajaran. Adapun penjelasan kegiatan implementasi kurikulum itu adalah pengembangan program. Pengembangan program kurikulum meliputi:

a. Pengembngan program tahunan. Program tahunan merupakan program umum setiap mata pelajaran untuk setiap kelas, yang dikembangkan oleh guru mata pelajaran yang bersangkutan. Program ini perlu

b. Program semester

c. Program modul

d. Program mingguan dan harian

e. Program pengayaan dan remedial

f.Program bimbingan dan konseling

Evaluasi hasil belajar dalam implementasi kurikulum saat ini dapat dilakukan dengan penilaian kelas, tes kemampuan dasar, penilaian akhir satuan pendidikan dan sertifikasi, benchmarking, dan penilaian program.

1. Penilaian kelas. Penilaian kelas dilakukan dengan ulangan harian, ulangan umum dan ujian akhir. Ulangan harian dilakukan setiap selesai proses pembelajaran dalam kompetensi tertentu. Ulangan haria terdiri dari seperangkat soal yang harus dijawab para peserta didik, dan tugas-tugas tersetruktur yang berkaitan dengan konsep yang sedang dibahas. 
2. Tes kemampuan dasar. Tes kemampuan dasar dilakukan untuk mengetahuai kemampuan membaca, menulis dan berhitung yang diperlukan dalam rangka memperbaiki program pembelajaran (program remedial). Tes kemampuan dasar dilakukan pada setiap tahun akhir kelas III.

3. Penilaian akhir satuan pendidikan dan sertifikasi. Pada setiap akhir semester dan tahun pembelajaran diselenggarakan kegiatan penilaian guna mendapatkan gambaran secara utuh dan menyeluruh mengenai ketuntasan belajar peserta didik dalam satua waktu tertentu. Untuk keperluan sertifikasi, kinerja dan hasil belajar yang dicantumkan dalam Surat Tanda Tamat Belajar (STTB) tidak semata-mata didasarkan atas hasil penilaian pada akhir jenjang sekolah.

4. Benchmarking. Benchmarking merupakan suatu standar untuk mengukur kinerja yang sedang berjalan, proses dan hasil untuk mencapai suatu keunggulan yang memuaskan

5. Penilaian program. Penilaian program dilakukan oleh Departemen Pendidikan Nasional dan Dinas Pendidikan secara countinue dan berkesinambungan. Penilaian program dilakuakan untuk mengetahui kesesuaian kurikulum dengan dasar, fungsi dan tujuan pendidikan nasional serta kesesuaiannyadengan tuntutan perkembangan masyarakat dan kemajuan zaman.

Setiap guru harus memahami tujuan penilaian kelas dengan baik agar fungsi yang telah disebutkan terlaksana. Jika dalam penilaian kelas, siswa jauh sekali dari pencapaian tujuan intruksional maka diharapkan guru segera mencari pemecahan masalahnya.

\section{Konsep implementasi kurikulum}

Berkaitan dengan implementasi kurikulum yang berbasis pada kompetensi (KBK dan KTSP) dikembangkan dengan berorientasi kepada pengembangan kepribadian (kurikulum humanistik), menuju kepada kurikulum yang berorientasi pada kehidupan dan alam pekerjaan (rekontuksi sosial dan teknologi). kurikulum humanistik dapat diberlakukan pada awal pendidikan 
dasar, di mana sejumlah kemampuan dasar untuk keprluan pengembangan pribadi seperti kemampuan membaca,menulis ,dan berpikir kritis, serta keberanian mengeluarkan ide atau gagasan, dan bekerja sama perlu ditonjolkan. pada jenjang menengah, barulah mereka belajar berdasarkan disiplin ilmu(subjek akademik) dengan tetap bersandar pada kehidupan dan lingkungan masyarakat sebagai sumber kurikulum (rekontruksi sosial dan teknologi).

Implementasi kurikulum seharusnya menempatkan pengembangan kreativitas siswa lebih dari penguasaan materi. Dalam 1kaitan ini, siswa ditempatkan sebagai subjek dalam proses pembelajaran. Komunikasi dalam pembelajaran yang multiarah sebagiannya dikembangkan sehingga pembelajaran kognitif dapat mengembangkan kemampuan berpikir sebaiknya dikembangkan dengan menekankan pada aktifitas siswa untuk mencari paemahaman akan objek, menganalisis dan merekonstruksi sehingga terbentuk pengetahuan baru dalam diri siswa.

Menurut Nana Syaodih S., (2001), Untuk mengimplementasikan kurikulum sesuai dengan rancangan, dibutuhkan beberapa kesiapan, terutama kesiapan pelaksanan. Sebagus apa apun desain atau rancangan kurikulum yang dimiliki, tetapi keberhasilannya sangat tergantung pada guru. Sumber daya pendidikan yang lain pun seperti sarana prasarana biaya,organisasi, lingkungan, juga merupakan kunci keberhasialan pendidikan, tetapi kunci utamannya adalah guru.

\section{Kemampuan guru dalam implementasi kurikulum}

Kemampuan-kemampuan yang harus dikuasai guru dalam mengimplementasikan kurikulum adalah sebagi berikut:

Pertama, pemahaman esensi dari tujuan-tujuan yang ingin dicapai dalam kurikulum.

Kedua, kemampuan untuk menjabarkan tujuan-tujuan kurikulum tersebut menjadi tujuan yang lebih spesifik.

Ketiga,kemampuan untuk menerjemahkan tujuan khusus kepada kegiatan pembelajaran. 
Kemampuan

-kemampuan tersebut mungkin sudah dikuasai oleh guru-guru dan para dosen, tetapi mungkin juga baru dikuasai sebagian atau sebagian guru yang menguasainya, perlu adanya kegiatan yang bersifat peningkatan atau penyegaran. Kegiatan tersebut dapat dilakukan melalui diskusi - diskusi ,simulasi dalam peergroup atau $\mathrm{MGMP/KKG}$ selain dilakukan melalui lokakarya ,pelatihan,penataran intern dengan mendatangkan narasumber.

Kendala yang dihadapkan dalam implementasi kurikulum ini adalah terutama berkenaan dengan:

1. Masih lemahnya diagnosis kebutuhan baik pada skala makra dan mikro sehingga implementasi kurikulum sering tidak sesuai yang diharapkan

2. Perumusan kompetensi pada tahapan mikro sering dikacaukan dengan intuksional yang dikembangkan .

3. Pemilihan pengalaman belajar yang dikembangkan;dan

4. Evaluasi sering tidak sesuai dengan tujuan intruksional yang dikembangkan;

Untuk mengantasipasi kendala yang dihadapi, maka perlu diupayakan hal-hal sebagai berikut.

Pertama, dalam mendiagnosisi kebutuhan sebagiannya masyarakat, baik dewan sekolah maupun komite sekolah dilibatkan sejak awal.

Kedua, dalam implementasi kurikulum guru mempunyai kewenangan penuh dalam menerapkan setrategi pembelajaran dan materi atau bahan pelajaran.

Ketiga, setruktur materi diorganisasikan mulai dari perencanan pengajaran dalam bentuk jam pelajaran,sampa dengan evaluasi menjadi satu kesatuan yang saling berkaitan. 


\section{Soal Latihan}

\section{Pilihan Ganda}

1. Penerapan KBK menuntut seorang guru untuk dapat merencanakan dan melaksanakan pembelajaran sesuai kondisi dan kebutuhan peserta didik serta melakukan evaluasi pembelajaran yang objektif. Tugas ini merupakan salah satu peran guru kecuali..
a. Guru kela
b. Staf sekola
c. Manage
d. Profesional

Jawaban: a

2. Hal-hal yang harus diperhatikan sekolah ketika membuat rencana tahunan adalah kecual...
a. Mempertimbangkan data dari hasil evaluasi dir
b. Menyusun draf rencana tahunan sekolah bersama semua sta
c. Mempertimbangkan pengalaman sekolah lain yang berhasil
d. Mempertimbangkan kontek lingkungan dan aspirasi masyarakat

Jawaban: d

3. Program yang dianjurkan pemerintah agar setiap sekolah dapat menjadi sekolah efektif adalah dengan menerapkan ...
a. Program unggulan
b. Manajemen Berbasis Sekolah
c. Life Skill
d. Kurikulum berbasis kompetensi

Jawaban: c 
4. Menurut para birokrat salah satu alasan mengapa Manajemen Berbasis Sekolah perlu diterapkan di Indonesia adalah....

a. Untuk meningkatkan fleksibilitas dalam hal pengelolaan

b. Perlunya reformasi dalam dunia pendidikan di Indonesia

c. Adanya pengelolaan melalui satu pintu yaitu sekolah

d. Efesiensi manajemen pendidikan dan upaya peningkatan mutu

Jawaban: d

5. Hal-hal yang harus diperhatikan sekolah ketika membuat rencana tahunan adalah kecual...
a. Mempertimbangkan data dari hasil evaluasi diri
b. Menyusun draf rencana tahunan sekolah bersama semua staf
c. Mempertimbangkan pengalaman sekolah lain yang berhasil
d. Mempertimbangkan kontek lingkungan dan aspirasi masyarakat

Jawaban: d

6. Salah satu Model Pendidikan yang dapat mengakomodasi berbagai kepentingan dan aspirasi masyarakat adalah model...
a. Kurikulum Berbasis Kompetensi
b. Multiple Inteligence
c. Manajemen Berbasis Sekolah
d. Ki Hajar Dewantoro
Jawaban: c

7. Pelaksanaan Ulangan Umum dan Ujian Nasional di suatu sekolah baik Negeri maupun swasta merupakan tanggung jawab dari .....
a. Kepala sekolah
b. Guru
c. Yayasan 


\section{d. Pemerintah}

Jawaban: a

8. Input dan proses pendidikan merupakan dua aspek yang saling berkaitan dan menentukan output pendidikan. Salah satu input pendidikan yang mempengaruhi proses pendidikan adalah....
a. Tenaga pengajar
b. Biaya pendidikan
c. Kurikulum
d. Teknologi

Jawaban: a

9. Bila kurikulum suatu sekolah dikembangkan untuk membantu siswa agar memiliki pengetahuan dan keterampilan yang berguna bagi kehidupannya, artinya sekolah tersebut telah memiliki fungsi ...
a. Sosial
b. Spiritual
c. Ekonomi
d. Politik

Jawaban: c

10. Upaya peningkatkan mutu dan relevansi pendidikan di Indonesia masih sulit dilakukan, salah satunya karena faktor input sekolah-sekolah masih rendah. Untuk kewujudkan sekolah efektif masalah tersebut dapat diatasi dengan ...

a. Memberi bantuan dana secukupnya kesekolah-sekolah

b. Memberikan training/pelatihan kepada personal sekolah

c. Membuat Standar Pelayanan Minimal

d. Melengkapi sarana dan prasarana sekolah

Jawaban: c 
1. Apa yang dimaksud dengan Kurikulum Berbasis Kompetensi (KBK)?

2. Apa yang dimaksud dengan Kurikulum Tingkat Satuan Pendidikan (KTSP)?

3. PERSAMAAN dan PERBEDAAN KBK dan KTSP?

4. Jelaskan prinsip-prinsip yang digunakan dalam pengembangan kurikulum?

5. Prinsip apakah yang menurut pendapat anda yang sering diabaikan oleh pemerintah dan guru ketika mengimplementasikan kurikulum?

Jawaban :

\section{Apa yang dimaksud dengan Kurikulum Berbasis Kompetensi (KBK)?}

Kurikulum berbasis kompetensi (KBK) adalah suatu konsep kurikulum yang menekankan pada pengembangan kemampuan melakukan (kompetensi) tugas-tugas dengan standar performansi tertentu, sehingga hasilnya dapat dirasakan oleh peserta didik, berupa penguasaan terhadap seperangkat kompetensi tertentu. Dengan demikian, implementasi kurikulum dapat menumbuhkan tanggung jawab, dan partisipasi peserta didik untuk belajar menilai dan mempengaruhi kebijakan umum (public policy), serta memberanikan diri berperan serta dalam berbagai kegiatan, baik di sekolah maupun dimasyarakat.

\section{Apa yang dimaksud dengan Kurikulum Tingkat Satuan Pendidikan (KTSP)?}

Dalam Standar Nasional Pendidkan ( SNP pasal 1 ayat 15) dikemukakan bahwa kurikulum tingkat satuan pendidkan ( KTSP) adalah kurikulum operasinal yang disusun oleh masing-masing satan pendidikan. Penyusunan KTSP dilakukan oleh Satuan Pendidikan dengan memperhatikan dan berdasarkan standar kompetensi serta kompetensi dasar yng dikembangkan oleh Badan Standar Nasional (BSNP). KTSP disusun dan dikembangkan berdasarkan Undang-undang no 20 Tahun 2003 tentang sistem pendidikan nasional pasal 36 ayat 1 dan 2 sebagai berikut: 
a. Pengembangan kurikulum mengacu pada standar nasional pendidikan untuk mewujudkan tujuan pendidikan nasional.

b. Kurikulum pada semua jenjang dan jenis pendidikan dikembangkan dengan prinsip diversifikasi sesuai dengan satuan pendidikan, potensi daerah, dan perserta didik.

KTSP merupakan strategi pengembangan kurikulum untuk mewujudkan sekolh yang efektif, produktif dan berprestasi. KTSP merupakan para digma aru pengembangan kurikulum yang memberikan otonomi luas pada satuan pendidikan dan pelibatan mayarakat dalam rangka mengefektifkan proses belajar mengajar disekolah.

\section{Persamaan dan perbedaan KBK dan KTSP?}

\section{Persamaan}

a. Kurikulum Berbasis Kompetensi (KBK) adalah kurikulum yang bertujuan untuk menciptakan tamatan yang kompeten dan cerdas dalam membangun identitas budaya dan bangsanya. Kurikulum ini dapat memberikan dasar-dasar pengetahuan, keterampilan, pengalaman belajar yang membangun integritas sosial, serta membudayakan dan mewujudkan karakter nasional.

b. Kurikulum Tingkat Satuan Pendidikan KTSP adalah kurikulum operasional yang disusun oleh dan dilaksanakan di masing-masing satuan pendidikan. KTSP terdiri dari tujuan pendidikan tingkat satuan pendidikan, struktur dan muatan kurikulum tingkat satuan pendidikan, kalender pendidikan, dan silabus. Silabus adalah rencana pembelajaran pada suatu dan/atau kelompok mata pelajaran/tema tertentu yang mencakup standar kompetensi, kompetensi dasar, materi pokok/pembelajaran, kegiatan pembelajaran, indikator, penilaian, alokasi waktu, dan sumber/bahan/alat belajar. Silabus merupakan penjabaran standar kompetensi dan kompetensi dasar ke dalam materi pokok/pembelajaran, kegiatan pembelajaran, dan indikator pencapaian kompetensi untuk penilaian. 


\section{Perbedaan}

a. Kurikulum Berbasis Kompensi memiliki karakteristik sebagai berikut :

1. Sistem belajar dengan modul

KBK mengunakan modul sebagai sistem. Dalam hal ini modul merupakan paket belajar mandiri yang meliputi serangkaian pengalaman belajar yang direncanakan dan dirancang secara sistematis untuk membantu peserta didik mencapai tujuan belajar. Tujuan utama sistem modul adalah untuk meningkatkan efisiensi dan efektifitas pembelajaran di sekolah, baik waktu, dana, fasilitas, maupun tenaga guna mencapai tujuan secara optimal.

2. Mengunakan keseluruhan sumber belajar

Untuk memperoleh hasil belajar yang optimal peserta didik dituntut tidak hanya mengandalkan diri dari apa yang terjadi di dalam kelas, tetapi harus mampu dan menulusuru aneka ragam sumber belajar yang di perlukan.

\section{Pengalaman lapangan}

KBK lebih menekankan pada pengalaman lapangan untuk mengakrabkan hubungan antara guru dan peserta didik. Keterlibatan angota tim guru dalam pembelajaran di sekolah memudahkan mereka untukmengikuti pembelajaran.

4. Strategi belajar individual personal

Belajar individual adalah belajar berdasarkan tempo belajar peserta didik, sedangkan belajar personal adalah interaksi edukatif berdasarkan keunikan peserta didik: bakat, minat dan kemampuan (personalisasi

5. Kemudahan belajar

Diberikan melalui kombinasi antara pembelajaran individual personal dan pengalaman lapangan dan pembelajaran secara tim.melalui berbagai saluran komunikasi.

6. Balajar tuntas 
Merupakan strategi pembelajaran yang dapat dilaksanakan didalam kelas dengan asumsi bahwa didalam kondisi yang tepat semua peserta didik akan mampu belajar dengan baik dan memperoleh hasil belajar yang maksimal terhadap seluruh bahan yang di pelajari

b. Kurikulum Tingkat Satuan Pendidikan memiliki karakteristik sebagai berikut :

1. Pemberian otonomi luas kepada sekolah dan satuan pendidikan

2. Partisipasi masyarakat dan orang tua yang tinggi

3. Kepemimpinan yang demokratis dan profesional

4. Tim kerja yang kompak dan transparan

\section{Jelaskan prinsip-prinsip yang digunakan dalam pengembangan kurikulum?}

Menurut Asep Herry Hernawan dkk (2002) mengemukakan lima prinsip dalam pengembangan kurikulum, yaitu :

1. Prinsip relevansi; secara internal bahwa kurikulum memiliki relevansi di antara komponen-komponen kurikulum (tujuan, bahan, strategi, organisasi dan evaluasi). Sedangkan secara eksternal bahwa komponenkomponen tersebut memiliki relevansi dengan tuntutan ilmu pengetahuan dan teknologi (relevansi epistomologis), tuntutan dan potensi peserta didik (relevansi psikologis) serta tuntutan dan kebutuhan perkembangan masyarakat (relevansi sosilogis).

2. Prinsip fleksibilitas; dalam pengembangan kurikulum mengusahakan agar yang dihasilkan memiliki sifat luwes, lentur dan fleksibel dalam pelaksanaannya, memungkinkan terjadinya penyesuaian-penyesuaian berdasarkan situasi dan kondisi tempat dan waktu yang selalu berkembang, serta kemampuan dan latar bekang peserta didik.

3. Prinsip kontinuitas; yakni adanya kesinambungan dalam kurikulum, baik secara vertikal, maupun secara horizontal. Pengalaman-pengalaman belajar yang disediakan kurikulum harus memperhatikan 
kesinambungan, baik yang di dalam tingkat kelas, antar jenjang pendidikan, maupun antara jenjang pendidikan dengan jenis pekerjaan.

4. Prinsip efisiensi; yakni mengusahakan agar dalam pengembangan kurikulum dapat mendayagunakan waktu, biaya, dan sumber-sumber lain yang ada secara optimal, cermat dan tepat sehingga hasilnya memadai.

5. Prinsip efektivitas; yakni mengusahakan agar kegiatan pengembangan kurikulum mencapai tujuan tanpa kegiatan yang mubazir, baik secara kualitas maupun kuantitas.

\section{Prinsip apakah yang menurut pendapat anda yang sering diabaikan oleh pemerintah dan guru ketika mengimplementasikan kurikulum?}

\section{a. Pemerintah;}

Pemerintah dalam melakukan pengembangan kurikulum, menurut saya tidak Efektif, misalnya dalam penerapan Kurikulum 2013. Dalam penerapannya, banyak daerah di Indonesia yang kurang siap dengan perubahan dari Kurikulum Tingkat Satuan Pendidikan ke Kurikulum 2013. Perubahan ini secara tidak langsung akan merubah sistem, model, alat peraga pendidikan maupun dari kesiapan guru itu sendiri dalam melakukan kegiatan pembelajaran dikelas.

Masalah efektif ini akan dapat diminimalisir ketika dalam penerapan kurikulum 2013 dapat ditunda, hingga semua pihak siap dengan adanya perubahan kurikulum ini.

Selain tidak memperhatikan prinsip Efektivitas, pemerintah juga tidak memperhatikan prinsip Efisien. Dimana dalam penggunaan media pendidikan misalnya buku. Peserta didik sebelumnya dapat menggunakan Buku KTSP dari kakak kelasnya, namun setelah adanya perubahan kurikulum, maka buku kakak kelasnya tidak bisa digunakan.

b. Guru atau Tenaga Pendidik 
Fleksibelitas merupakan keluawesan dalam mengambangkan kurikulu. Prinsip ini kurang diperhatikan oleh Guru, terbukti dengan banyaknya Mata Pelajaran yang diajarkan tidak mudah dipahami oleh peserta didik. 


\section{BAB IX}

\section{EVALUASI MANAJEMNE KURIKULUM PADA SATUAN PENDIDIKAN}

\section{A. KOMPETENSI}

Memahami, menganalisis, mengevaluasi, pengetahuan tentang Evaluasi Manajemen pada Satuan Pendidikan

\section{B. TUJUAN}

1. Untuk mengetahui Evaluasi Manajemen Kurikulum pada Satuan Pendidikan

2. Untuk memahami komponen-komponen Evaluasi Manajemen Kurikulum pada Satuan Pendidikan

3. Untuk dapat memahami dan mengetahui tentang tujuan tentang Evaluasi Manajemen pada Satuan Pendidikan

\section{MATERI}

a. Pengertian Evaluasi Kurikulum

Menurut S. Hamid Hasan (2008:32), evaluasi kurikulum dan evaluasi pendidikan memiliki karakteristik yang tak terpisahkan. Karakteristik itu adalah lahirnya berbagai definisi untuk suatu istilah teknis yang sama. Demikian pula dengan evaluasi yang diartikan oleh berbagai pihak dengan berbagai pengertian. Hal tersebut disebabkan filosofi keilmuan yang dianut seseorang berpengaruh terhadap metodologi evaluasi, tujuan evaluasi, dan pada gilirannya terhadap pengertian evaluasi.

Rumusan evaluasi menurut Gronlund adalah suatu proses yang sistematis dari pengumpulan, analisis dan interpretasi informasi/data untuk menentukan sejauh mana siswa telah mencapai tujuan pembelajaran. Sementara itu, Hopkins dan Antes mengemukakan evaluasi adalah pemeriksaan secara terusmenerus untuk mendapatkan informasi yang meliputi siswa, guru, program pendidikan, dan proses belajar mengajar untuk mengetahui tingkat perubahan siswa dan ketepatan keputusan tentang gambaran siswa dan efektivitas program. 
Menurut Tyler (1949) evaluasi berfokus pada upaya untuk menentukan tingkat perubahan yang terjadi pada hasil belajar. Hasil belajar tersebut biasanya diukur dengan tes. Tujuan evaluasi menurut Tyler, yaitu untuk menentukan tingkat perubahan yang terjadi, baik secara statistik, maupun secara eduktif. (Rusman 2008:93)

b. Evaluasi Manajemen Kurikulum

Evaluasi kurikulum Memegang peranan penting baik dalam penentuan kebijaksanaan pendidikan pada umumnya, maupun pada pengambilan keputusan dalam kurikulum.Hasil-hasil evaluasi dapat digunakan oleh para pemegang kebijaksanaan pendidikan dan para pengembang kebijaksanaan pengembangan sistem pendidikan dan pengembangan model kurikulum yang digunakan.(Sukmadinata 2010:172)

Menurut Tyler evaluasi berfokus pada upaya untuk menentukan tingkat perubahan yang terjadi pada hasil belajar. Hasil belajar tersebut biasanya diukur dengan tes. Tujuan evaluasi menurut Tyler, yaitu untuk menentukan tingkat perubahan yang terjadi, baik secara statistik, maupun secara edukatif. (Rusman 2008:93)

Sedangkan menurut pendapat Nana Sudjana menjelaskan bahwa evaluasi adalah proses penentuan nilai sesuatu berdasarkan kriteria tertentu, yang dalam proses tersebut tercakup usaha untuk mencari dan mengumpulkan data atau informasi yang diperlukan sebagai dasar dalam menentukan nilai sesuatu yang menjadi objek evaluasi, seperti program, prosedur, usul, cara, pendekatan, model kerja, hasil program, dan lain sebagainya. Berdasarkan beberapa pendapat di atas maka evaluasi berkaitan dengan proses sekaligus alat untuk menentukan nilai sesuatu berdasarkan kriteria tertentu yang berfungsi sebagai bahan masukan untuk menentukan sebuah keputusan.

Tujuan evaluasi kurikulum berbeda-beda tergantung dari konsep atau pengertian seseorang tentang evaluasi. Konsep seseorang tentang evaluasi dipengaruhi oleh pandangan filosofis seseorang tentang posisi evaluasi sebagai suatu bidang kajian dan sebagai suatu profesi. ( Hamid 2009:43) 
Menurut Stufflenbeam, dkk (1971), tujuan utama evaluasi kurikulum adalah memberikan informasi terhadap pembuat keputusan, atau untuk penggunaannya dalam proses menggambarkan hasil, dan memberikan informasi yang berguna untuk membuat pertimbangan berbagai alternatif keputusan. (Rusman 2008: 97)

Evaluasi kurikulum dimaksudkan untuk memeriksa tingkat ketercapaian tujuan pendidikan yang ingin diwujudkan melalui kurikulum yang bersangkutan. Indikator kinerja yang akan dievaluasi di sini adalah efektivitas program. Dalam arti luas evaluasi kurikulum dimaksudkan untuk memeriksa kinerja kurikulum secara keseluruhan ditinjau dari berbagai kriteria. Indikator kinerja yang dievaluasi adalah efektivitas, relevansi, efisiensi, dan kelayakan program.

Dalam bukunya Scriven (1967) sebagaimana yang dikutip oleh Rusman dalam buku nya manajemen kurikulum membuat perbedaan antara evaluasi sumatif dan formatif. Dalam evaluasi sumatif, evaluasi berfungsi untuk menetapkan keseluruhan penilaian program. Termasuk menilai keseluruhan manfaat program tertentu dalam hubungannya dengan kontribusi terhadap kurikulum sekolah secara total. Menurut Scriven, evaluasi sumatif tidak untuk menentukan sebab, hanya manfaat dari sebuah program.

Evaluasi formatif meliputi pembuatan penilaian dan usaha untuk menentukan sebab-sebab khusus. Informasi yang diperoleh dalam evaluasi formatif memberi kontribusi terhadap revisi program ini memungkinkan pengembangan kurikulum untuk mengubah dan mengembangkan kurikulum sebelum menetapkan bentuk final. Perbedaan yang mendasar antara dua tipe evaluasi ini menyangkut bagaimana evaluasi diperlukan, apa yang akan dievaluasi, dan bagaimana hasilnya akan digunakan. (Rusman 2008: 101)

c. Prinsip-prinsip Evaluasi Kurikulum

Prinsip-prinsip evaluasi kurikulum adalah sebagai berikut :

1. Tujuan tertentu, artinya setiapo program evaluasi kurikulum terarah dalam mencapai tujuan yang telah ditentukan secara jelas dan spesifik. Tujuantujuan itu pula yang mengarahkan berbagai kegiatan dalam proses pelaksanaan evaluasi kurikulum. 
2. Bersifat objektif, dalam artian berpijak pada keadaan yang sebenarnya, bersumber dari data yang nyata dan akurat, dan diperoleh melalui instrument yang andal.

3. Bersifat komprehensif, mencangkup semua dimensi atau aspek yang terdapat dalam ruang lingkungan kurikulum. Seluruh komponen kurikulum harus mendapat perhatian dan pertimbangan secara seksama sebelum dilakukan pengambilan keputusan.

4. Kooperatif dan berbertanggung jawab dalam perencanaan. Pelaksanaan dan keberhasilan suatu program evaluasi kurikulum merupakan tanggung jawab bersama pihak-pihak yang terlibat dalam proses pendidikan seperti guru, kepala sekolah, penilik, orang tua, bahkan siswa itu sendiri, disamping merupakan tanggung jawab utama lembaga penelitian dan pengembangan.

5. Efiseien,khususnya dalam penggunaan waktu, biaya, tenaga, dann peralatan yang menjadi unsure penunjang. Oleh karena itu, harus diupayakan agar hasil evaluasi lebih tinggi, atau paling tidak berimbang dengan materi yang digunakan.

6. Berkesinambungan. Hal ini diperlukan mengingat tuntutan dari dalam dan luar system sekolah, yang meminta diadakannya perbaikan kurikulum. Untuk itu, peran guru dan kepala sekolah sangan lah penting, karena mereka yang paling mengetahui, pelaksanaan, permasalahan, dan keberhasilan kurikulum.( Hamalik 2007 : 255-256)

\section{d. Komponen-Komponen Kurikulum}

Kurikulum dapat diumpamakan sebagai suatu orgasme manusia ataupun binatang, yang memiliki susunan anatomi tertentu. Unsur atau komponenkomponen dari anatomi tubuh kurikulum yang utama adalah tujuan, isi atau materi, proses atau sistem penyampaian dan media, serta evaluasi. Keempat komponen tersebut berkaitan erat satu sama lain.

Suatu kuritkulum harus memiliki kesesuaian atau relevansi. Kesesuaian ini meliputi dua hal. Pertama, kesesuaian antara kurikulum dengan tuntutan, kebutuhan, kondisi, dan perkembangan masyarakat. Kedua kesesuaian antara komponen-komponen kurikulum yaitu isi sesuai dengan tujuan, proses sesuai 
dengan isi dan tujuan, demikian juga evaluasi sesuai dengan proses, isi dan tujuan kurikulum. (Sukmadinata 2010:102)

Dilihat dari uraian struktural kurikulum, ada 4 komponen utama yakni:

1. Tujuan

2. Isi dan struktur kurikulum

3. Strategi pelaksanaan, dan lainnya

4. Komponen evaluasi

Keempat komponen tersebut saling berkaitan satu sama lainnya sehingga merefleksikan satu kesatuan yang utuh sebagai program pendidikan.

1. Tujuan

Tiap satuan pendidikan harus mengacu ke arah pencapaian tujuan pendidikan nasional, sebagaimana telah ditetapkan dalam Undang-undang RI no. 20 Tahun 2003 tentang sistem Pendidikan nasional pasal 3. (UUD RI 2003:6)

Pendidikan Nasional bertujuan untuk berkembangnya potensi anak didik agar menjadi manusia yang beriman dan bertakwa kepada Tuhan YME, berakhlak mulia, sehat, berilmu, cakap, kreatif, mandiri,dan menjadi warga Negara yang demokratis, serta bertanggung jawab.

Pada dasarnya tujuan pembelajaran merupakan tujuan dari setiap program pendidikan yang akan diberikan kepada anak didik, dan kurikulum merupakan alat untuk mencapai tujuan pendidikan. Rumusan tujuan pembelajaran tersebut harus terlebih dahulu ditetapkan, sebab:

a. Tujuan berfungsi menentukan arah dan corak kegiatan pendidikan

b. Tujuan menjadi indikator dari keberhasilan pelaksanaan pendidikan. 
c. Tujuan menjadi pegangan dalam setiap usaha dan tindakan dari pelaksanaan pendidikan. (Zaini 2009:82)

2. Isi dan struktur kurikulum

Isi kurikulum berkaitan dengan pengetahuan ilmiah dan pengalaman belajar yang harus diberikan kepada siswa dalam rangka mencapai tujuan pendidikan. Untuk menentukan isi kurikulum tersebut harus disesuaikan dengan tingkat dan jenjang pendidikan perkembangan yang terjadi dalam masyarakat, perkembangan ilmu pengetahuan dan teknologi, disamping juga tidak terlepas dari kaitannya dengan kondisi anak didik (psikologis anak) pada setiap jenjang pendidikan tersebut.(Nurdin dan Usman 2003:54)

\section{Strategi pembelajaran}

Dalam pelaksanaan suatu kurikulum adalah cara yang digunakan untuk menyampaikan materi pelajaran dalam upaya mencapai tujuan pembelajaran. Suatu strategi pembelajaran mengandung pengertian terlaksananya kegiatan guru dan kegiatan siswa dalam proses pembelajaran. (Hamalik 2007:24)

\section{Evaluasi Kurikulum}

Bilamana kurikulum dipandang sebagai sebuah sistem, maka dapat diidentifikasi sebagai berikut: (1) masukan (input), (2) proses pelaksanaan program, (3) hasil (output) program, (4) balikan yang merupakan dampak dari program tersebut. Evaluasi terhadap input kurikulum mencakup evaluasi sumber daya yang dapat menunjang program pendidikan, seperti; dana, sarana, tenaga, konteks sosial, dan penilaian terhadap siswa sebelum menempuh program (pre tes).

Evaluasi proses mencakup penilaian terhadap strategi pelaksanaan kurikulum, yang berkenaan dengan proses belajar mengajar, bimbingan dan 
penyuluhan, administrasi supervisi, sarana pengajaran, dan penilaian hasil belajar. ( Nurdin dan usman 2003:59)

Dalam melakukan penilaian, yang harus diperhatikan adalah:

\section{Sasaran penilaian}

Sasaran atau objek evaluasi belajar adalah perubahan tingkah laku yang mencakup bidang kognitif, afektif dan psikomotor secara seimbang. Masing-masing bidang berdiri sejumlah aspek dan aspek tersebut hendaknya dapat diungkapkan melalui penilaian tersebut. Dengan demikian dapat diketahui tingkah laku mana yang sudah dikuasainya dan mana yang belum sebagai bahan perbaikan dan penyusunan program pengajaran selanjutnya.

\section{Alat penilaian}

Penggunaan alat penilaian hendaknya komprehensif, yang meliputi tes dan non tes, sehingga diperoleh gambaran hasil belajar yang objektif. Demikian pula bentuk tes tidak hanya tesobjektif tetapi juga tes essay, sedangkan jenis non tes digunakan untuk menilai aspek tingkah laku, seperti aspek minat dan sikap. Alat evaluasi non tes, antara lain: observasi, wawancara, study kasus dan ratingscale (skala penilaian). Penilaian hasil belajar dalam Kurikulum Tingkat Satuan Pendidikan (KTSP) dapat dilakukan antara lain:

\section{a. Penilaian kelas}

Penilaian kelas dilakukan dengan ulangan harian, ulangan umum dan ujian akhir. Penilaian kelas dilakukan oleh guru untuk mengetahui kemampuan dan hasil belajar peserta didik, mendiagnosa kesulitan belajar, memberikan umpan balik untuk perbaikan proses pembelajaran dan penentuan kenaikan kelas.(Mulyasa 2006:258)

b. Tes kemampuan dasar 
Tes kemampuan dasar untuk mengetahui kemampuan membaca, menulis dan berhitung yang diperlukan dalam rangka memperbaiki program pembelajaran (program remedial). Tes kemampuan dasar dilakukan pada setiap tahun akhir kelas tiga.

c. Penilaian akhir satuan pendidikan

Pada setiap akhir semester dan tahun pelajaran diselenggarakan kegiatan penilaian guna mendapatkan gambaran secara utuh dan menyeluruh mengenai ketuntasan belajar peserta didik dalam satuan waktu tertentu.

\section{d. Benchmarking}

Benchmarking merupakan suatu standar untuk mengukur kinerja yang sedang berjalan, proses dan hasil untuk mencapai suatu keunggulan yang memuaskan. Ukuran keunggulan dapat ditentukan di tingkat sekolah, daerah, atau nasional. Penilaian dilaksanakan secara berkesinambungan sehingga peserta didik dapat mencapai satuan tahap keunggulan pembelajaran yang sesuai dengan kemampuan usaha keuletannya.

e. Penilaian program

Penilaian program dilakukan oleh Departemen Pendidikan Nasional dan Dinas Pendidikan secara kontinu dan berkesinambungan. Penilaian program dilakukan untuk mengetahui kesesuaian KTSP dengan dasar, fungsi dan tujuan pendidikan nasional, serta kesesuaiannya dengan tuntutan perkembangan masyarakat, dan kemajuan zaman. (Mulyasa 2006:261) 
D. Soal 10 Pilihan Ganda dan 5 Essai,

1. Siapa peneliti yang menyebutkan evaluasi kurikulum dan evaluasi pendidikan memiliki karakteristik yang tak terpisahkan?
a. Gronlund
c. Hopkins dan Antes
b. Tyler
d. S. Hamid Hasan.

2. Siapa pengamatan yang menyebutkan evaluasi adalah suatu proses yang sistematis dari pengumpulan, analisis dan interpretasi informasi/data untuk menentukan sejauh mana siswa telah mencapai tujuan pembelajaran?
a. Gronlund.
c. Hopkins dan Antes
b. Tyler
d. S. Hamid Hasan

3. Siapa pengemuka yang menyebutkan evaluasi berfokus pada upaya untuk menentukan tingkat perubahan yang terjadi pada hasil belajar?
a. Gronlund
c. Hopkins dan Antes
b. Tyler.
d. S. Hamid Hasan

4. Pada tahun berapa buku Scriven yang dikutip oleh Rusman dalam buku nya manajemen kurikulum membuat perbedaan antara evaluasi sumatif dan formatif?
a. 1967.
c. 1956
b. 1976
d. 1947

5. Pada tahun berapa Stufflenbeam, dkk menyebutkan, tujuan utama evaluasi kurikulum adalah memberikan informasi terhadap pembuat keputusan, atau untuk penggunaannya dalam proses menggambarkan hasil, dan memberikan informasi yang berguna untuk membuat pertimbangan berbagai alternatif keputusan
a. 1987.
c. 1917
b. 1971
d. 1978

6. Ada berapakah komponen-komponen kurikulum? 

a. tiga
c. empat.
b. dua
d. lima

7. Pada tahun berapa Undang-undang RI no. 20 yang menyebutkan tentang sistem Pendidikan nasional pasal 3.38Pendidikan Nasional bertujuan untuk berkembangnya potensi anak didik agar menjadi manusia yang beriman dan bertakwa kepada Tuhan YME, berakhlak mulia, sehat, berilmu, cakap, kreatif, mandiri,dan menjadi warga Negara yang demokratis, serta bertanggung jawab?
a. 2006
c. 2004
b. 2005
d. 2003.

8. Ada berapa sebab rumusan tujuan pembelajaran tersebut harus terlebih dahulu ditetapkan?
a. tiga.
c. lima
b. empat
d. enam

9. Dalam melakukan penilaian ada disebut sasaran penilaian,siapakah maksud sasaran penilaian tersebut?
a. guru
c. masyarakat
b. siswa.
d. dokter

10. Ada berapa penilaian hasil belajar dalam Kurikulum Tingkat Satuan Pendidikan (KTSP) dapat dilakukan?
a. lima.
c. tujuh
b. empat
d. delapan 
Soal Essai

1. Menurut pendapat Nana Sudjana menjelaskan bahwa evaluasi adalah?

2. Dari uraian struktural kurikulum, ada 4 komponen utama yakni?

3. Sebutkan rumusan tujuan pembelajaran tersebut harus terlebih dahulu ditetapkan!

4. Apa yang dimaksud dengan strategi pembelajaran?

5. Sebutkan penilaian hasil belajar dalam Kurikulum Tingkat Satuan Pendidikan (KTSP) dapat dilakukan antara lain.

Kunci Jawaban Pilihan Ganda

1. d

2. a

3. $b$

4. a

5. a

6. c.

7. d

8. a

9. $\mathrm{b}$

10. a

Kunci Jawaban Essai

1. Adalah proses penentuan nilai sesuatu berdasarkan kriteria tertentu, yang dalam proses tersebut tercakup usaha untuk mencari dan mengumpulkan data atau informasi yang diperlukan sebagai dasar dalam menentukan nilai sesuatu yang menjadi objek evaluasi, seperti program, prosedur, usul, cara, pendekatan, model kerja, hasil program, dan lain sebagainya. 
2. -Tujuan, -Isi dan struktur kurikulum, -Strategi pelaksanaan, dan lainnya, -Komponen evaluasi.

3. -Tujuan berfungsi menentukan arah dan corak kegiatan pendidikan, -Tujuan menjadi indikator dari keberhasilan pelaksanaan pendidikan, -Tujuan menjadi pegangan dalam setiap usaha dan tindakan dari pelaksanaan pendidikan.

4. Cara yang digunakan untuk menyampaikan materi pelajaran dalam upaya mencapai tujuan pembelajaran. Suatu strategi pembelajaran mengandung pengertian terlaksananya kegiatan guru dan kegiatan siswa dalam proses pembelajaran.

5. - Penilaian kelas, - Tes kemampuan dasar, - Penilaian akhir satuan pendidikan, - Benchmarking, - Penilaian program. 


\section{BAB X}

\section{TUGAS POKOK DAN FUNGSI MANAJER DAN PERSONIL SATUAN PENDIDIKAN DALAM MANAJEMEN KURIKULUM}

\section{A. KOMPETENSI}

Memahami, menganalisis, mengevaluasi pengetahuan tentang Tugas Pokok dan Fungsi Manajer dan Personil Satuan Pendidikan dalam Manajemen Kurikulum.

\section{B. TUJUAN}

1. Untuk mengetahui tugas pokok dari manajer dan satuan pendidikan dalam manajemen kurikulum.

2. Untuk mengetahui fungsi dari manjaer dan satuan pendidikan dalam manajemen kurikulum.

3. Untuk memahami tugas pokok dan fungsi manajer dan satuan pendidikan dalam manajemen kurikulum.

\section{MATERI}

\section{Tugas dan fungsi personil satuan pendidikan}

1. Kepala sekolah

Kepala sekolah merupakan seorang manajer di sekolah yang harus bertanggung jawab terhadap perencanaan, pelaksanaan, dan penilaian perubahan atau perbaikan program pengajaran di sekolah. Sedikitnya terdapat empat langkah yang harus dilakukan yaitu menilai kesesuaian program yang ada dengan tuntutan kebudayaan dan kebutuhan murid, meningkatkan perencanaan program, memilih dan melaksanakan program, serta menilai perubahan program

Untuk menjalankan efektivitas pengembangan kurikulum dan program pengajaran dalam MBS, kepala sekolah sebagai pengelola program pengajaran bersama guru-guru harus menjabarkan isi kurikulum secara lebih rinci dan operasional kedalam program tahunan, catur wulan dan bulanan. Adapun program mingguan ataupun program satuan pelajaran, wajib 
dikembangkan guru sebelum melaksanakan kegiatan belajar mengajar (Rohiat, 2008:41)

Menurut (Triwiyanto, 2015: 71-71) tugas kepala sekolah yang berkenaan dengan manajemen kurikulum dan pembelajaran pada kompetensi manajerial, meliputi :

a) Menyusun perencanaan jangka pendek, jangka menengah, jangka panjang yang meliputi kebutuhan pendidik, pembagian tugas mengajar, kelengkapan alat dan bahan pelajaran, serta semua kegiatan sekolah.

b) Mengadakan evaluasi terhadap semua kegiatan di sekolah.

c) Menyelenggarakan evaluasi bagi siswa dan ujian sekolah.

d) Melakukan supervisi terhadap proses belajar mengajar, kegiatan bimbingan dan konseling, kegiatan ekstrakulikuler dan intrakulikuler, kegiatan ketatausahaan sekolah, dan kegiatan kerjasama dengan masyarakat dan instansi lain.

e) Menyusun penjabaran kalender pendidikamenyusun dan mengelola evaluasi pembelajaran

f) Senantiasa meningkatkan stabilitas dan mutu pendidikan.

g) Merencanakan, mengoordinasi dan mengawasi proses pembelajaran tambahan (ekstra).

h) Menyelenggarakan pelatihan untuk meningkatkan kemampuan akademik pendidik menuju profesionalitas.

i) Memantau kualitas pelaksanaan proses pembelajaran di kelas.

j) Melaksanakan supervisi.

k) Mendokumentasikan laporan kegiatan evaluasi (ulangan umum dan ujian akhir)

1) Memantau pembuatan rencana pengajaran pendidik.

m) Membina dan memeriksa penyusunan satuan pelajaran, daya serap siswa, deposit soal, program remedial, dan pengayaan soal.

Seorang kepala sekolah memiliki fungsi yang disebut dengan fungsi supervisi kurikulum. Supervisi kurikulum adalah semua usaha yang dilakukan dalam bentuk pemberian bantuan, bimbingan, penggerakan 
motivasi, nasihat dan pengarahan yang bertujuan untuk meningkatkan kemampuan guru dalam peroses belajar-mengajar, yang pada gilirannya bertujuan untuk meningkatkan hasil belajar siswa. Sebagai seorang kepala sekolah harus mampu melakukan berbagai pengawasan dan pengendalian ini merupakan kontrol agar kegiatan pendidikan terarah pada tujuan yang telah ditentukan. Pengawasan dan pengendalian juga merupakn tindakan preventif untuk mencegar agar para tenaga pendidik tidak melakukan penyimpangan dan lebih berhati-hati dalam melaksanakan pekerjaannya.

Pada dasarnya supervisor kurikulum memiliki lima fungsi, sebagai berikut:

a) Fungsi edukatif, sebagai usaha untuk menciptakan tenaga pengajar yang lebih mampu dan lebih baik kualitasnya.

b) Fungsi kurikuler, yakni berkenaan dengan pelaksanaan, pengajaran dan peningkatan situasi belajar-mengajar sehingga siswa dapat belajar secara lebih efektif. Hal ini dimaksudkan untuk membantu guru yang mengalami kesulitan dalam melaksanakan kurikulum sekolah.

c) Fungsi pembimbingan, yakni memberikan bantuan kepada guru agar mampu mengatasi kesulitan guru dalam melaksanakan tanggung jawab kependidikannya.

d) Fungsi administratif, fungsi ini berkenaan dengan kegiatan pengawasan dan kepemimpinan terhadap organisasi dalam rangka kependidikan dan pengajaran sekolah.

e) Fungsi pengabdian, yakni berkenaan dengan pengabdian supervisor terhadap kepentingan sekolah, seperti membantu guru, membantu siswa, dan menyelenggarakn sistem sekolah secara menyeluruh.

Kepala sekolah sebagai supervisor harus diwujudkan dalam kemampuan menyusun dan melaksanakan program supervisi pendidikan serta dapat memanfaatkan hasilnya. Kemampuan menyusun supervisi pendidikan harus diwujudkan dalam penyusunan program supervisi kurikulum, pengembangan 
program, supervisi untuk kegiatan ekstrakulikuler, pengembangan program supervisi perpustakaan, laboratorium dan ujian (Rohiat, 2008: 183).

2. Wakil kepala sekolah

Tugas dan fungsi wakil kepala sekolah urusan kurikulum, adalah sebagai berikut :

a) Menyusun program kerja bidang kurikulum

b) Memberdayakan guru agar mampu menyediakan dokumen-dokumen kurikulum

c) Mengkoordinasikan penyusunan dan revisi kurikulum tingkat satuan pendidikan

d) Memfasilitasi guru untuk mengembangkan kompetensi dasar setiap mata pelajaran.

e) Membantu kepala sekolah dalam pembagian tugas mengajar guru

f) Menyusun peraturan akademik

g) Menyusun kalender pendidikan

h) Membuat jadwal pembelajaran

i) Memfasilitasi guru untuk menyusun administrasi pembelajaran setiap mata pelajaran

j) Memfasilitasi guru untuk memilih buku sumber yang sesuai untuk setiap mata pelajaran

k) Memfasilitasi guru dalm mengembangkan dan memperbaiki proses pengajaran

1) Mengidentifikasi kebutuhan dalam bagi pengembangan kurikulum lokal

m) Mengkoordinasi pelaksanaan penilaian akhir semester, penilaian akhir tahun, ujian dan ujian nasional.

n) Mengkoordinasi pengolahan niali penilaian akhir semester, penilaian akhir tahun, ujian dan ujian nasional.

o) Menetapkan kriteria naik/tidak kelas dan kriteria kelulusan. 
p) Mengatur jadwal penerimaan buku laporan penilaian hasil belajar dan ijazah.

q) Mengevaluasi pelaksanaan kegiatan kurikulum

r) Membuat laporan pelaksanaan kurikulum secara berkala kepada kepala sekolah.

3. Komite sekolah

Komite sekolah merupakan salah satu bentuk organisasi yang merangkul dan mewadahi serta berusaha menyatukan visi dan misi komponen-komponen pendidikan yang terdapat dalam masyarakat untuk meningkatkan mutu pendidikan pada satuan pendidikan yang berkaitan dengan masyarakat tersebut khususnya dan juga merupakan pemandirian satuan lembaga pendidikan dalam meningkatkan mutu pendidikan mereka masing-masing khususnya masalah pembiayaan pendidikan, tanpa harus ketergantungan kepada pembiayaan yang disediakan oleh pemerintah pusat melalui APBNnya dan pemerintah daerah melalui APBD-nya yang tidak akan pernah mencukupi kebutuhan pada satuan-satuan pendidikan dalam upaya menjadi suatu lembaga pendidikan yang bermutu dan berkualitas (Kompri, 2014: $360)$.

Menurut ( Kompri, 2014: 368) fungsi komite sekolah antara lain sebagai berikut :

a) Memberi pertimbangan (advisory agency), dalam memberdayakan masyarakat dan lingkungan sekolah serta menentukan, melaksanakan kebijakan pendidikan.

b) Mendukung (supporting agency), kerjasama sekolah dalam masyarakat baik secara finansial, pemikiran maupun tenaga dalam penyelenggaraan pendidikan.

c) Mengontrol (controling agency), kerjasama sekolah dengan masyarakat dalam rangka transparansi dan akuntabilitas penyelenggara pendidikan. 
d) Mediator antara sekolah, pemerintah (eksekutif), dewan perwakilan rakyat daerah (DPRD/legislatif), dengan masyarakat.

e) Mendorong tumbuhnya perhatian dan komitmen masyarakat terhadap penyelenggaraan pendidikan yang bermutu.

f) Melakukan kerjasama dengan masyarakat (perorangan/organisasi) dan dunia kerja, pemerintah, DPRD dalam rangka menyelenggarakan pendidikan yang berkualitas.

g) Memberikan masukan, pertimbangan, dan rekomendasi kepada pemerintah daerah berkaitan dengan kebijakan dan program pendidikan.

Tugas komite sekolah antara lain sebagai berikut:

a) Memberi pertimbangan dalam penentuan dan pelaksanaan kebijakan pendidikan di satuan pendidikan.

b) Pendukung baik yang bersifat finansial, pemikiran, maupun tenaga dalam penyelenggaraan pendidikan di satuan pendidikan.

c) Pengontrol dalam rangka transparansi dan akuntabilitas penyelenggaraan pendidikan dalam satuan pendidikan.

d) Mediator antara pemerintah dan masyarakat di satuan pendidikan.

4. Bagian perpustakaan

Perpustakaan ditujukan sebagai pelengkap dari proses pendidikan yang isinya merupakan buku-buku yang berkaitan dengan materi ajar yang disampaikan dalam kurikulum pendidikan. Perpustakaan memiliki fungsi sebagai tempat penyimpanan dan memelihara koleksi kepustakaan berupa buku dan hasil riset.

Pustakawan adalah petugas perpustakaan yang memegang peranan penting dalam penyelenggaraan perpustakaan dan juga merupakan faktor yang menentukan berhasil atau tidaknya pelayanan yang ada di perpustakaan.

Berikut ini merupakan Tugas pokok seorang pustakawan, yaitu: 
a) Mengumpulkan dan mengolah data dalam rangka menyusun rencana operasional pengembangan koleksi.

b) Mengumpulkan data dalam rangka survei minat pemakai

c) Mengumpulkan dan mengolah data dalam rangka menyusun rencana operasional pengolahan bahan pustaka.

d) Menghimpun alat seleksi bahan pustaka

e) Merawat bahan pustaka dalam rangka pencegahan

f) Melakukan pelayanan perpustakaan

g) Menelaah pengembangan di bidang perpustakaan, dokumentasi dan informasi.

Fungsi perpustakaan sekolah adalah sebagai berikut :

a) Fungsi edukatif, perpustakaan sekolah menyediakan buku-buku baik buku fiksi maupun nonfiksi. Buku-buku tersebut dapat membiasakan murid untuk belajar mandiri. Selain itu perpustakaan sekolah menyediakan buku-buku yang sesuai dengan kurikulum sekolah, hal ini dapat menunjang penyelenggaraan pendidikan di sekolah.

b) Fungsi informatif, perpustakaan sekolah menyediakan majalah, bulletin, surat kabar, pamphlet, artikel, peta bahkan juga dengan alatalat pandang-dengar, seperti projektor, televisi, tape recorder dan sebagainya. Semua ini akan memberikan informatif yang diperlukan oleh murid-murid oleh sebab itu, perpustakaan sekolah memiliki fungsi informatif.

c) Fungsi tanggung jawab administratif, fungsi ini tampak pada kegiatan sehari-hari di perpustakaan sekolah. Setiap peminjaman dan pengembalian buku selalu di catatoleh pustakawam. Setiap murid yang amsuk harus menunjukan kartu anggota perpustakaan, tidak boleh mengganggu temannya yang lagi belajar, jika murid telat mengembalikan buku pinjamannya maka harus didenda, jika menghilagkan bukunya maka harus mengganti dengan buku yang 
baru. Semua itu untuk mendidik murid agar bersikap dan bertindak secara administratif.

d) Fungsi riset, perpustakaan menyediakan banyak bahan pustaka, adanya bahan pustaka yang lengkap ini membuat pemustaka dapat melakukan riset yaitu dengan mengumpulkan data-data yang dibutuhkan.

e) Fungsi rekreatif, perpustakaan sekolah dapat dipakai untuk mengisi waktu luang seperti pada waktu istirahat dengan cara membaca buku cerita, novel, roman, majalah, surat kabar, dan sebagainya.

\section{Guru}

Guru merupakan penentu keberhasilan pendidikan melalui kinerjanya pada tingkat institusional dan instruksional peran strategis tersebut sejalan dengan Undang-Undang Nomor 14 tahun 2005 tentang guru dan dosen.Sebagai tenaga profesional pekerjaan guru hanya dapat di lakukan oleh seseorang yang mempunyai kualifikasi akademik,kompetensi, dan sertifikat pendidikan sesuai dengan persyaratan untuk setiap jenis dan jenjang pendidikan tertentu kedudukan guru sebagai agen pembelajaran antara lain sebagai fasilitator,motivator,pemacu ,perekayasa pendidikan dan pemberi inspirasi belajar bagi peserta didik peran tersebut menuntut guru untuk mampu meningkatkan kinerja dan profesionalismenya seiring dengan perubahan dan tuntutan yang muncul terhadap dunia pendidikan dewasa ini (Karwati, 2014: 61)

Menurut (Karwati,2014: 61-65) guru merupakan faktor penentu yang sangat dominan dalam proses pembelajaran peserta didik terkait dengan hal tersebut maka fungsi guru meliputi banyak hal,yaitu:

a) Pendiagnosa perilaku peserta didik

Guru harus mampu memahami dan memberikan solusi atas segala kesulitan yang dihadapi peserta didik dalam proses pembelajaran untuk 
itu guru dituntut untuk mengenal lebih dekat kepribadian peserta didiknya.

b) Penyusun Rencana Pelaksanaan Pembelajaran (RPP)

Pelaksanaan pembelajaran yang baik harus didukung dengan perencanaan yang baik, karena rencana yang baik akan meminimalisir risiko pembelajaran yang buruk dan tidak terarah.

c) Pelaksana proses pembelajaran

Guru harus mampu melaksanakan proses pembelajaran dengan baik,karena kualitas proses pembelajaran akan menentukan hasil akhir yang akan dicapai oleh peserta didik.

d) pelaksana administrator sekolah

Guru dapat berperan sebagai administrator sekolah yang berfungsi untuk membantu kepala sekolah dan tata usaha sekolah ini emungkinkan guru untuk mengetahui peserta didik tidak hanya sebatas kepetingan akademik namun juga kepentingan administratif peserta didik.

e) penyebar komunikasi dan komunikator

ini terkait dengan proses penyampaian informasi oleh guru,baik kepada dirinya sendiri,kepada pesrta didik,kepada pemimpinnya, kepada orang tua peserta didik,maupun kepada masyarakat.

f) pengemban potensi pesrta didik

guru harus mampu mengembangkan strategi pembelajaran yang mampu mengoptimalkan kemampuan yang dimiliki peseta didik.

g) pengembang kurikulum di sekolah

guru merupakan ujung tombak yang mengimplementasikan kurikulum disekolah, sehingga guru merupakan jembatan antara kurikulum yang dikembangkan oleh pemerintah dan pelaksana ditingkat sekolah peran strategis tersebut meunutut guru untuk mampu mengembangkan kurikulum ditingkat sekolah sesuai dengan kemampuan sekolah dan kondisi peserta didik 
Tingkat keerhasilan guru dalam menyelesaikan pekerjaannya disebut denga istilah "level of performance" atau level kinerja, guru yang memiliki kinerja tinggi merupakan guru yang memiliki produktivitas kerja sama dengan atau diatas standar yang ditentukan,begitupun sebaliknya guru yang memiliki level kinerja rendah maka guru tersebut merupakan guru yang tidak produktif (Karwati, 2014: 66).

\section{Administrasi sekolah}

Garapan administrasi sekolah dilhat dari sudut pandang yang sempit terdiri dari Pertama Administrasi tata laksana sekolah,seperti laporan anggaran,rencana anggaran,dan pendapatan belanja sekolah (RAPBS),surat menyurat,administrasi pegawai dan lain sebagainya,Kedua administrasi guru dan pegawai sekolah,Ketiga supervisi pendidikan dan keempat yaitu pelaksanaan dan pembinaan kurikulum

Administrasi sekolah memiliki tugas pokok yaitu:

a) melayani pelaksaan pekerjaan operatif untuk mencapai tujuan dari suatu organisasi

b) menyediakan keterangan keterangan bagi pucuk pimpinan organisasi itu untuk membuat keputusan

c) membantu kelancaran perkembangan organisasi sebagai suatu keseluruhan

terdapat beberapa komponen yang sangat penting untuk mendukung peningkatan keberhasilan penyelenggaraan dan salah satu yang pokok tersebut adalah penyelenggaraan administrasi yang dalam lingkup makro disebut juga administrasi sekolah.tanpa adanya adminitrasi sekolah yang baik maka kemungkinan sekali segala upaya kegiatan peningkatan mutu bidang pendidikan akan gagal sama sekali,bidang atau aspek apapun yang dibenahi akhirnya kembali pada persyaratan utama yaitu,penyelenggaraan pendidikan baik sebagai sarana maupun sebagai alat penataan bagi komponen pendidikan lainnya. 
Dalam rangka peningkatan mutu pelayanan kinerja berbagai sumber daya dalam kegiatan administrasi sekolah,maka perlu memperhatikan beberapa prinsip yang harus diperhatikan yaitu :

a) Prinsip efisiensi

Administrator sekolah akan berhasil dalam tugasnya bila dia menggunakan semua sumber tenaga,dana,dan fasillitas yang ada secara efisien

b) Prinsip pengelolaan

Administrator akan memperoleh hasil yang efektif dan efisien dengan melakukan pekerjaan manajemen yang baik,yakni merencanakan,mengorganisasikan,mengarahkan,dan melakukan pemeriksaan

c) Prinsip pengutamaan tugas pengelolaan

Seseorang administrator cenderung memprioritaskan perhatiannya pada pekerjaan operatif,namun seharusnya ia tidak selalu memfokuskan perhatiannya pada pekerjaan operatif saja,maka pekerjaan pokonya akan terbengkalai

d) Prinsip kepemimpinan yang efektif

Seorang administrator akan berhasil dalam tugasnya apabila memilih gaya kepemimpinan yang efektif,yakni memperhatikan hubungan antar manusia,pelaksanaan tugas serta memperhatikan situasi dan kondisi yang ada.

7. Laboran

Laboran adalah orang yang bertugas membantu aktivitas siswa di labolatorium dalam melakukan suatu kegiatan pendidikan dan penelitian kurikulum.dalam melakukan tugasnya seorang laboran bertanggung jawab dalam menyediakan peralatan yang diperlukan untuk kegiatan praktikum atau penelitian.laboran terdiri dari:

a. Teknisi 
Orang yang berperan untuk beroperasinya peralatan labolatorium misalnya listrik, air, komputer dan perbengkelan.

b. Analisis

Orang yang mempuyai keahlian untuk melalukan analisis pada bidang tertentu Laboran teknisi maupun analisi yang handal sangat diperlukan maka selayaknya mereka mempunyai keahlian atau kompetensi di bidangnya.

Tugas laboran:

a) Melaksanakan kegiatan praktikum siswa

b) Menyediakan fasilitas labolatorium untuk kegiatan penelitian atau karya ilmiah

c) Membuat dan menyusun daftar alat alat labolatorium

d) Menyusun laporan pelaksanaan kegiatan labolatorium secara berkala

e) Inventarisasi dan pengadministrasian alat alat labolatorium

Fungsi laboran:

a) Mendata alat dan bahan praktikum

b) Mencatat kegiatan praktikum

c) Merawat ruang labolatorium

d) Melayani kegiatan praktikum

e) Menjaga kesehatan dan keselamatan kerja di labolatorium 


\section{SOAL DAN LATIHAN}

\section{Pilihan ganda}

1. kelompok layanan pendidikan yang menyelenggarakan pendidikan pada jalur formal, nonformal dan informal pada setiap jenjang dan jenis pendidikan, merupakan pengertian dari?
a. Kurikulum
b. Satuan pendidikan
c. Manajemen
d. Komite sekolah
e. Organisasi

2. orang yang bertugas membantu aktivitas siswa di labolatorium dalam melakukan suatu kegiatan pendidikan dan penelitian kurikulum adalah?
a. Pustakawan
b. Laboran
c. Manajer
d. Kepala sekolah
e. Wakil kepala sekolah kesiswaan

3. proses merencanakan,mengorganisasikan, memimpin dan mengendalikan atau mengawasi upaya organisasi dengan segala aspek agar tujuan organisasi tercapai secara efektif dan efisien, merupakan pengertian dari?
a. Manajemen
b. Kurikulum
c. Administrasi
d. Organisasi
e. Analisis

4. perpustakaan menyediakan banyak bahan pustaka, merupakan salah satu fungsi perpustakaan yaitu?
a. Fungsi riset
b. Fungsi rekreatif
c. Fungsi informative
d. Fungsi edukatif 

e. Fungsi tanggung jawab administrasi

5. Berikut ini merupakan fungsi laboran, kecuali?
a. Mendata alat dan bahan praktikum
b. Mencatat kegiatan praktikum
c. Merawat ruang labolatorium
d. Melayani kegiatan praktikum
e. Menyediakan dan merawat buku pelajaran

6. berkenaan dengan pelaksanaan, pengajaran dan peningkatan situasi belajar-mengajar sehingga siswa dapat belajar secara lebih efektif, merupakan fungsi kepala sekolah sebagai?
a. Fungsi kurikuler
b. Fungsi edukatif
c. Fungsi pengembangan
d. Fungsi pembimbingan
e. Fungsi administratif

7. Salah satu bentuk organisasi yang merangkul dan mewadahi serta berusaha menyatukan visi dan misi komponen-komponen pendidikan yang terdapat dalam masyarakat, merupakan pengertian dari?
a. Administrasi sekolah
b. Komite sekolah
c. Manajer sekolah
d. Laboran
e. Pustakawan

8. kerjasama sekolah dengan masyarakat dalam rangka transparansi dan akuntabilitas penyelenggara pendidikan, merupakan salah satu fungsi komite sekolah yaitu?
a. Memberi pertimbangan
b. Mengontrol
c. Mendukung
d. Mediator
e. Memberi masukan 
9. berkenaan dengan pengabdian supervisor terhadap kepentingan sekolah, seperti membantu guru, membantu siswa, dan menyelenggarakn sistem sekolah secara menyeluruh, merupakan salah satu fungsi kepala sekolah yaitu?
a. Fungsi pengabdian
b. Fungsi edukatif
c. Fungsi pembimbing
d. Fungsi kurikuler
e. Fungsi administrative

10. Merencanakan dan melaksanakan proses pendidikan, menilai hasil pembelajaran, melakukan pembimbingan dan pelatihan, merupakan tugas seorang guru menurut?
a. Undang-Undang Nomor 20 tahun 2003, pasal 39 ayat 2
b. Undang-Undang Nomor 21 tahun 2003, pasal 39 ayat 2
c. Undang-Undang Nomor 20 tahun 2007, pasal 39 ayat 2
d. Undang-Undang Nomor 20 tahun 2003, pasal 39 ayat 3
e. Undang-Undang Nomor 20 tahun 2003, pasal 29 ayat 2

\section{Essay}

1. Sebutkan tugas pokok komite sekolah!

Jawaban:

1) Memberi pertimbangan dalam penentuan dan pelaksanaan kebijakan pendidikan di satuan pendidikan.

2) Pendukung baik yang bersifat finansial, pemikiran, maupun tenaga dalam penyelenggaraan pendidikan di satuan pendidikan.

3) Pengontrol dalam rangka transparansi dan akuntabilitas penyelenggaraan pendidikan dalam satuan pendidikan.

4) Mediator antara pemerintah dan masyarakat di satuan pendidikan.

2. Sebutkan tugas pokok seorang laboran!

Jawaban:

1) Melaksanakan kegiatan praktikum siswa 
2) Menyediakan fasilitas labolatorium untuk kegiatan penelitian atau karya ilmiah

3) Membuat dan menyusun daftar alat alat labolatorium

4) Menyusun laporan pelaksanaan kegiatan labolatorium secara berkala

5) Inventarisasi dan pengadministrasian alat alat labolatorium

3. Sebutkan dan jelaskan fungsi dari seorang pustakawan!

Jawaban:

1) Fungsi edukatif, perpustakaan sekolah menyediakan buku-buku baikbuku fiksi maupun nonfiksi. Buku-buku tersebut dapat membiasakan murid untuk belajar mandiri.

2) Fungsi informatif, perpustakaan sekolah menyediakan majalah, bulletin, surat kabar, pamphlet, artikel, peta bahkan juga dengan alatalat pandang-dengar, seperti projektor, televisi, tape recorder dan sebagainya.

3) Fungsi tanggung jawab administratif, fungsi ini tampak pada kegiatan sehari-hari di perpustakaan sekolah.

4) Fungsi riset, perpustakaan menyediakan banyak bahan pustaka, adanya bahan pustaka yang lengkap ini membuat pemustaka dapat melakukan riset yaitu dengan mengumpulkan data-data yang dibutuhkan.

5) Fungsi rekreatif, perpustakaan sekolah dapat dipakai untuk mengisi waktu luang seperti pada waktu istirahat dengan cara membaca buku cerita, novel, roman, majalah, surat kabar, dan sebagainya.

4. Sebutkan tugas pokok kepala sekolah sebagai seorang manajer! Jawaban:

1) Memberdayakan tenaga kependidikan melalui kerjasama.

2) Memberi kesempatan kepada para tenaga kependidikan untuk meningkatkan profesinya.

3) Mendorong ketertiban seluruh tenaga kependidikan.

5. Sebutkan dan jelaskan fungsi guru di sekolah!

Jawaban: 
a) Pendiagnosa perilaku peserta didik

Guru harus mampu memahami dan memberikan solusi atas segala kesulitan yang dihadapi peserta didik dalam proses pembelajaran untuk itu guru dituntut untuk mengenal lebih dekat kepribadian peserta didiknya

b) Penyusun Rencana Pelaksanaan Pembelajaran (RPP)

Pelaksanaan pembelajaran yang baik harus didukung dengan perencanaan yang baik, karena rencana yang baik akan meminimalisir risiko pembelajaran yang buruk dan tidak terarah.

c) Pelaksana proses pembelajaran

Guru harus mampu melaksanakan proses pembelajaran dengan baik,karena kualitas proses pembelajaran akan menentukan hasil akhir yang akan dicapai oleh peserta didik.

d) pelaksana administrator sekolah

guru dapat berperan sebagai administrator sekolah yang berfungsi untuk membantu kepala sekolah dan tata usaha sekolah ini memungkinkan guru untuk mengetahui peserta didik tidak hanya sebatas kepetingan akademik namun juga kepentingan administratif peserta didik.

e) penyebar komunikasi dan komunikator ini terkait dengan proses penyampaian informasi oleh guru,baik kepada dirinya sendiri,kepada pesrta didik,kepada pemimpinnya,kepada orang tua peserta didik,maupun kepada masyarakat

f) pengemban potensi pesrta didik guru harus mampu mengembangkan strategi pembelajaran yang mampu mengoptimalkan kemampuan yang dimiliki peseta didik

g) pengembang kurikulum di sekola guru merupakan ujung tombak yang mengimplementasikan kurikulum disekolah,sehingga guru merupakan jembatan antara kurikulum yang dikembangkan oleh pemerintah dan pelaksana ditingkat sekolah peran 
strategis tersebut meunutut guru untuk mampu mengembangkan kurikulum ditingkat sekolah sesuai dengan kemampuan sekolah dan kondisi peserta didik

\section{KUNCI JAWABAN}

1. B

2. B

3. A

4. A

5. E

6. A

7. B

8. B

9. A

10. A 


\section{BAB X1}

\section{INOVASI DALAM IMPLEMENTASI MANAJEMEN KURIKULUM}

A. Kompetensi

B. Tujuan Pembelajaran

\section{Materi}

\section{Pengertian}

Secara etimologi inovasi berasal dari kata latin innovaation yang berarti pembaharuan dan perubahan. Kata kerjanya innovo yang artinya memperbarui dan mengubah. Inovasi ialah suatu perubahan baru yang menuju ke arah perbaikan dan berencana (tidak secara kebetulan saja). (Idris, 1992:70).

Di dalam kamus besar Bahasa Indonesia, Inovasi di artikan pemasukan satu pengenalan hal-hal yang baru; penemuan baru yang berbeda dari yang sudah ada atau yang sudah dikenal sebelumnya(gagasan, metode atau alat) (tim penyusun kamus pusat pembinaan dan pengembangan bahasa, 1989:333).

Setelah perencanaan kurikulum selesai disusun, maka pemerintah menyiapkan atau menetapkan kebijakan untuk memberlakukan atau melaksanakan kurikulum. Pelaksanaan kurikulum berarti proses mewujudkan kurikulum dalam realisasi pembelajaran di sekolah-sekolah. Untuk pelaksanaan kurikulum, maka guru dituntut untuk secara profesional merancang pembelajaran efektif dan bermakna (menyenangkan), mengorganisasikan pembelajaran, memilih pendekatan, dan pembentukan kompetensi secara aktif serta menerapkan kriteria keberhasilan.

Secara etimologi kata kurikulum diambil dari bahasa Yunani, Curere berarti jarak yang harus ditempuh oleh pelari dari mulai atau start sampai finish. Pengertian inilah yang kemudian diterapkan dalam bidang pendidikan.

Dalam bahasa Arab, kurikulum sering disebut dengan istilah al-manhaj yang berarti jalan yang terang yang dilalui manusia dalam bidang 
kehidupannya. Berdasarkan pengertian tersebut, kurikulum jika dikaitkan dengan pendidikan. Menurut Muhaimin kurikulum berarti jalan terang yang dilalui oleh pendidik atau guru dengan peserta didik untuk mengembangkan pengetahuan, keterampilan dan sikap serta nilai-nilai. Keberhasilan proses pembelajaran di sebuah lembaga pendidikan tidak bisa terlepas dari kurikulum. Dalam konteks ini, kurikulum mempunyai kedudukan yang sentral dalam proses pendidikan karena kurikulum mengarahkan segala bentuk aktifitas pendidikan dengan tujuan tercapainya tujuan pendidikan. Kurikulum memberikan rancangan pendidikan yang berfungsi memberikan pedoman dalam proses pendidikan. Sedangkan dalam terminologi, terdapat perbedaan pengertian kurikulum.

Dalam pengertian lama kurikulum didefinisikan sebagai sejumlah materi pelajaran yang harus ditempuh dan dipelajari oleh peserta didik untuk memperoleh sejumlah pengetahuan, yang telah tersusun secara sistematis dan logis. Pendefinisian ini walau terasa kurang tepat, tetapi memang ada benarnya jika ditarik dari asal kata kurikulum di atas tadi, yakni curere yang biasa diartikan dengan jarak yang harus ditempuh oleh pelari. Berdasarkan pengertian ini, sebetulnya ingin dikatakan bahwa kurikulum lebih menekankan pada isi pelajaran dari sejumlah mata pelajaran yang berada di sekolah atau madrasah yang harus ditempuh para peserta didik untuk mencapai suatu ijazah. Kurikulum juga merupakan keseluruhan mata pelajaran yang disajikan oleh suatu lembaga pendidikan. Pengertian ini terasa masih sangat sempit, karena kurikulum tidak lain hanya sejumlah materi saja.

Dalam pengertian lain Ramayulis mendefinisikan bahwa kurikulum merupakan salah satu komponen yang sangat penting menentukan dalam suatu sistem pendidikan, karena itu kurikulum merupakan alat untuk mencapai tujuan pendidikan dan sekaligus sebagai pedoman dalam pelaksanaan pengajaran pada semua jenis dan tingkat pendidikan.

Menurut Syarifuddin (2017:71) menyatakan kurikulum adalah seluruh bahan pelajaran yang harus disajikan dalam proses kependidikan dalam satu sistem institusional pendidikan. 
Dari beberapa definisi di atas dapat disimpulkan, bahwa kurikulum merupakan sejumlah mata pelajaran atau kegiatan yang mencakup program pendidikan agar mencapai tujuan pendidikan yang diharapkan. Definisi tersebut kemudian berkembang sesuai dengan tuntutan dan dinamika zaman. Kegiatan pengembangan kurikulum harus dilakukan berdasarkan ilmu manajemen karena pengembangan kurikulum menuntut adanya perencanaan sampai dengan pengawasan bahkan termasuk monitoring dan evaluasi. Sebuah kurikulum lembaga pendidikan yang diatur dan dikembangkan dengan baik akan menghasilkan peserta didik yang sesuai dengan tujuan pendidikan nasional.

Kurikulum merupakan seperangkat rencana dan pengaturan mengenai isi bahan pelajaran serta cara yang digunakan sebagai pedoman untuk menggunakan aktivitas belajar mengajar. Kurikulum dipandang sebagai program pendidikan yang direncanakan dan dilaksanakan dalam mencapai tujuan pendidikan yang memerlukan sebuah inovasi dan pengembangan. Karenanya kurikulum selalu bersifat dinamis, selalu berubah, menyesuaikan diri dengan kebutuhan mereka yang belajar.

Hal ini dikarenakan masyarakat dan siapa saja yang belajar mengalami perubahan juga. Pengembangan rencana pembelajaran dan pelaksanaan bimbingan merupakan bagian dari isi kurikulum, isi kurikulum bukan hanya mata pelajaran saja, tetapi ditambah dengan proses pembelajaran di luar mata pelajaran semisal kerja keras, kedisiplinan, kebiasaan belajar, dan jujur dalam belajar. Semua itu merupakan tanggung jawab sekolah yang wajib diberikan kepada peserta didik.

Dalam pengertian tersebut terlihat jelas, bahwa kegiatan-kegiatan kurikulum tidak terbatas dalam ruang kelas saja melainkan juga mencakup kegiatan di luar kelas. Dengan demikian tidak ada pemisahan tegas antara intra dan ekstra kurikulum. Singkatnya, semua kegiatan yang memberi pengalaman dalam proses pendidikan atau belajar bagi peserta didik, pada hakikatnya adalah kurikulum. Oleh karenanya, dalam pengertian yang sangat 
luas ini kurikulum sering dimaknai dengan sejumlah pengalaman belajar yang didapat oleh peserta didik baik di dalam maupun di luar kelas.

Dari beberapa definisi di atas, terdapat berbagai penafsiran dan pemahaman tentang kurikulum, sehingga kita peroleh penggolongan kurikulum sebagaimana dikatakan Majid sebagai berikut:

a) Kurikulum dapat dilihat sebagai produk, yakni sebagai hasil karya pengembangan kurikulum, biasanya dalam suatu panitia. Hasilnya dituangkan dalam bentuk buku atau pedoman kurikulum, misalnya berisi sejumlah mata pelajaran yang harus diajarkan. Inilah yang disebut dengan dokumen kurikulum.

b) Kurikulum dapat pula dipandang sebagai program, yakni alat yang dilakukan oleh sekolah atau madrasah untuk mencapai tujuannya. Ini dapat berupa mengajarkan berbagai mata pelajaran, tetapi dapat juga meliputi segala kegiatan yang dianggap dapat mempengaruhi perkembangan siswa. Misalnya perkumpulan sekolah, pertandingan, pramuka, warung sekolah dan lain-lain.

c) Kurikulum dapat pula dipandang sebagai hal-hal yang diharapkan agar dapat dipelajari oleh siswa yakni pengetahuan, sikap, keterampilan tertentu. Apa yang diharapkan akan dipelajari tidak selalu sama dengan apa yang benar-benar dipelajari.

d) Kurikulum sebagai pengalaman siswa. Ketiga pandangan di atas berkenaan dengan perencanaan kurikulum. Sedangkan pandangan yang keempat ini mengenai ini mengenai apa yang secara actual menjadi kenyataan pada setiap siswa. Ada kemungkinan, bahwa apa yang diwujudkan pada diri anak berbeda dengan apa yang diharapkan menurut rencana.

Dari berbagai macam pengertian kurikulum diatas, secara garis besar kurikulum dapat disimpulkan sebagai seperangkat rencana dan pengaturan mengenai tujuan, isi, dan bahan pelajaran serta cara yang digunakan sebagai pedoman penyelenggaraan kegiatan pembelajaran untuk mencapai tujuan pendidikan tertentu. 


\section{Inovasi dalam Implementasi Manajemen Kurikulum}

a) Dari sisi bentuk dan organisasi inovasinya berupa perubahan dari Kurikulum tahun 1947 yang disebut Rencana Pelajaran Dirinci Dalam Rencana Pelajaran Terurai (17 tahun) menjadi kerikulum tahun 1964 Rencana Pendidikan Dasar (4 tahun) menjadi kurikulum tahun 1968 Kurikulum Sekolah Dasar (6 tahun) menjadi kurikulum tahun 1974 Kurikulum Proyek Perintis Sekolah Pembangunan (1 tahun) menjadi kurikulum tahun 1975 Kurikulum Sekolah Dasar (9 tahun) menjadi kurikulum 1984 Kurikulum Cara Belajar Siswa Aktif (KCBSA) (10 tahun), menjadi Kurikulum 1994 (3 tahun), pada tahun 1997 Revisi Kurikulum 1994 (7 tahun), pada tahun 2004 menjadi Kurikulum Berbasis Kompetensi (KBK) (2 tahun), menjadi kurikulum tahun 2006 Tingkat Satuan Pendidikan (KTPS) (7 tahun). Dan, tahun 2013 ini pemerintah berencana menerapkan kurikulum baru 2013 yang menurut rencana diberlakukan bulan Juli 2013.

b) Dari sisi psikologi timbul masalah berkenaan dengan pendekatan belajarmengajar yang baru, maka muncul berbagai inovasi seperti keterampilan proses, dan belajar tuntas.

c) Dari sisi sosiologis timbul masalah berkenaan dengan tuntutan masyarakat modern yang semakin tinggi dan kompleks sehingga muncul 1 inovasi berupa masuknya mata pelajaran keterampilan, adanya kerja dan gagasan muatan lokal.

d) Dari sisi penyampaian pengajaran, inovasi berupa sistem modul paket untuk pendidikan luar sekolah dan metode SAS (Struktural Analisis Sintesis) untuk belajar membaca Alquran.

e) Pembelajaran melalui komputer adalah bentuk pembelajaran yang dirancang secara individual dengan cara siswa berinteraksi secara langsung dengan materi pelajaran yang diprogram secara khusus melalui sistem komputer. Dengan demikian, melalui komputer siswa dapat belajar sendiri dari mulai pengenalan tujuan yang harus dicapai, pengalaman 
belajar yang harus dilakukan sampai mengetahui tingkat keberhasilannya sendiri dalam pencapaian tujuan.

Dalam bidang pendidikan, inovasi biasanya muncul dari adanya keresahan pihak-pihak tertentu tentang penyelenggaraan pendidikan. Misalkan, keresahan guru tentang pelaksanaan proses belajar mengajar yangdianggapnya kurang berhasil, keresahan pihak administrator pendidikan tentang kinerja guru, atau mungkin keresahan masyarakat terhadap kinerja dan hasil bahkan sistem pendidikan.Keresahan-keresahan itu pada akhirnya membentuk permasalahan-permasalahan yang menuntut penanganan dengan segera. Upaya untuk memecahkan masalah itulah muncul gagasan dan ide-ide baru sebagai suatu inovasi. Dengan demikian, maka dapat kita katakan bahwa inovasi itu ada karena adanya masalah yang dirasakan; hampir tidak mungkin inovasi muncul tanpa adanaya masalah yang dirasakan.

\section{Soal}

\section{Pilihan Ganda}

1. Secara etimologi inovasi berasal dari bahasa?
a. Latin
c. Indonesia
b. Arab
d. Yunani

2. Secara etimologi inovasi berasal dari kata innovation yang memiliki arti?
a. Pembukuan
c. Pembaharuan dan perubahan
b. Pembaharuan
d. Perubahan

3. Secara etimologi kurikulum berasal dari bahasa?
a. Amerika
c. Latin
b. Yunani
d. Indonesia

4. "Kurikulum merupakan salah satu komponen yang sangat penting menentukan dalam suatu sistem pendidikan, karena itu kurikulum merupakan alat untuk mencapai tujuan pendidikan dan sekaligus sebagai pedoman dalam pelaksanaan pengajaran pada semua jenis dan tingkat pendidikan." Definisi tersebut kemukakan oleh? 

a. Ramayulis
c. Yono
b. Tubagus
d. Ahmad

5. Menurut M. Arifin mendefinisikan kurikulum adalah seluruh bahan pelajaran yang harus disajikan dalam proses kependidikan dalam satu sistem?
a. Institusional Pendidikan
c. Perubahan Pendidikan
b. Institut Pendidikan
d. Pembaharuan Pendidikan

6. Indonesia sering sekali berinovasi dalam bergati kurikulum tentunya demi perbaikan pendidikan di Indonesia, sudah berapa kali Indonesia berganti kurikulum?
a. 20
c. 15
b. 11
d. 12

7. Kurikulum pada tahun berapakah yang paling lama di gunakan untuk pendidikan di Indonesia?
a. 2002
c. 2013
b. 1947
d. 1999

8. Di bawah ini salah satu contoh inovasi kurikulum ialah...
a. Pembelajaran melalui computer
b. Pembelajaran di ruang kelas
c. Pembelajaran dengan buku
d. Pembelajaran di kantin

9. Kurikulim memerlukan suatu Inovasi yang bertujuan untuk...
a. Sistem pendidikan semakin baik
b. Mengubahnya saja
c. Pembaharuan
d. Kemajuan

10. Dibawah ini faktor terjadinya inovasi adalah...
a. Adanya perubahan
b. Adanya suatu masalah yang dirasakan
c. Adanya perubahan dan pembaharuan
d. Adanya suatu ketakutan 


\section{Essai}

1. Dalam etimologi dan beberapa istilah kurikulum diambil dari beberapa bahasa dan pengertian, salah satunya istiliah "jalan terang yang dilalui oleh manusia dalam bidang kehidupan nya" coba jelaskan menurut anda istiliah tersebut !

2. Tahap pengertian tentang kurikulum terbagi menjadi 2 fase, bisa dikatakan terbagi dalam fase lama dan fase baru. Coba anda jelaskan secara rinci kesimpulan dari kedua fase tersebut !

3. Dalam metode khusu pembentukan suatu unsur pembaharuan dalam inovasi dilihat dari beberapa implementasi. Coba anda sebutkan apa saja tahap yang menyangkut dalam implementasi inovasi tersebut!

4. Coba anda sebutkan dari tahun berapa hingga tahun berapa kurikulum pendidikan di Negara kita melawati sistem inovasi yang pernah terjadi!

5. Ada beberapa faktor yang mendorong terjadinya atau adanya inovasi, coba jelaskan salah satu faktor pendorong terjadinya atau adanya faktor yang mendotong terjadinya atau adanya inovasi!

\section{Jawaban}

\section{Pilihan Ganda}

$\begin{array}{ll}\text { 1. A } & 6 . \mathrm{B} \\ \text { 2. C } & 7 . \mathrm{B} \\ \text { 3. B } & 8 . \mathrm{A} \\ \text { 4. A } & 9 . \mathrm{A} \\ \text { 5. A } & 10 . \mathrm{B}\end{array}$

\section{$\underline{\text { Essai }}$}

1. Menurut saya istilah itu memiliki arti sama seperti yang pernah dikatakan oleh Muhaimin, yaitu jalan terang yang dilalui oleh pendidik dan peserta didik untuk mengembangkan keterampilan, pengetahuan serta sikap terhadap nilai-nilai. 
2. Secara garis besar kesimpulan dari kedua fase tersebut bahwa kurikulum merupakan sejumlah mata pelajaran atau kegiatan yang mencangkup program pendidikan agar mencapai tujuan pendidikan yang diharapkan.

3. Inovasi implementasi tersebut adalah
a. Bentuk dan Organisasi
b. Psikologi
c. Sosiologis
d. Penyampaian
e. Media pembelajaran

4. Dimulai dari tahun 1947, 1968, 1974, 1975, 1984, 1994, 1997, 2004, 2006, dan terakhir tahun 2013.

5. Salah satunya adalah keresahan sistem yang sudah tidak sesuai atau tidak sejalan dengan target yang dituju, sehingga menghasilkan ide-ide dan gagasan untuk pemberbaharuinya. Maka demikian dapat disimpulkan salah satu faktor pendorong adanya inovasi yaitu karena adanya suatu masalah yang dirasakan. Hampir tidak mungkin terjadi inovasi jika tidak ada masalah yang dirasakan. 


\section{BAB X1I \\ KOMPETENSI DALAM PENYUSUNAN JADWAL DITINGKAT SATUAN \\ PENDIDIKAN}

\section{A. KOMPETENSI}

Kompetensi dalam penyusunan jadwal ditingkat satuan pendidikan.

\section{B. TUJUAN}

Mahasiswa memahami Kompetensi Dalam Penyusunan Jadwal di Tingkat Satuan Pendidikan.

\section{MATERI}

1. Pengertian kurikulum tingkat satuan pendidikan

Kurikulum tingkat satuan pendidikan (KTSP) adalah kurikulum operasional yang disusun dan dilaksanakan oleh masing-masing satuan pendidikan.

Menurut UU nomor 20 tahun 2003 tentang Sistem Pendidikan Nasional menyebutkan bahwa, Kurikulum adalah seperangkat rencana dan pengaturan mengenai tujuan, isi, dan bahan pelajaran, serta cara yang digunakan sebagai pedoman penyelenggaraan kegiatan pembelajaran untuk mencapai tujuan pendidikan tertentu.

2. Kurikulum berbasis kompetensi (KBK)

Pengertian kompetensi menurut undang-undang republik indonesia nomor 20 tahun 2003 pada pasal 35 ayat (1) bahwa kompetensi adalah kualifikasi kemampuan lulusan yang mencakup sikap, pengetahuan, dan keterampilan sesuai dengan standard nasional yang telah disepakati. Undang-undang republik indonesia 13 tahun 2003 tentang ketenagakerjaan pada pasai 1 ayat (10) memberi rambu-rambu bahwa kompetensi adalah kemampuan kerja setiap individu yang mencakup aspek pengetahuan, keterampilan dan sikap kerja yang sesuai dengan standard yang ditetapkan.

Kompetensi merupakan sesuatu yang abstrak. Wina Sanjaya $(2009 ; 131)$ menyatakan bahwa kompetensi adalah perpaduan dari pengetahuan, 
keterampilan, kemampuan, nilai dan sikap yang direflesikan dalam kebiasaan berfikir dan bertindak.

Kompetensi tidak hanya sekedar mengetahui atau memahami sesuatu tetapi juga menghayatinya dan tercermin dalam pola perilaku sehari-hari. Sukmadinata (2004) dalam bukunya yang berjudul kurikulum dan pembelajaran kompetensi mengatakan bahwa kompetensi identik dengan life skill yaitu kecakapan, kebiasaan, keterampilan, kegiatan, perbuatan, dan performansi yang dapat diamati dan diukur.

3. Penyusunan Kurikulum Tingkat Satuan Pendidikan mencakup komponen:

1. pengembangan visi dan misi sekolah,

2. perumusan tujuan pendidikan satuan pendidikan,

3. pengembangan dan penyusunan struktur KTSP,

4. penyusunan kalender pendidikan,

5. pengembangan silabus, dan

6. pengembangan rencana pelaksanaan pembelajaran (RPP).

Untuk itu, diperlukan proses dan waktu yang cukup panjang dalam pengembangan kurikulum, diantaranya.

\section{a. Menganalisi konteks}

Sesuai dengan komponen yang dikembangankan tersebut, tahap pertama yang harus dilakukan dalam pengembangan KTSP adalah menganalisi konteks.

1) Menganalisis potensi, kekuatan, dan kelemahan yang ada di sekolah dan satuan pendidikan, baik yang berkaitan dengan siswa, guru, kepala sekolah, dan tenaga administrasi, sarana dan prasarana, serta pembiayaan, dan program-program yang ada di sekolah.

2) Menganalisis peluang dan tantangan yang ada di masyarakat dan lingkungan sekitar, baik yang bersumber dari komite sekolah, dewan pendidikan, dinas pendidikan, dunia industri dan dunia kerja, serta sumber daya alam dan sosial budaya. 


\section{b. Penyusunan Komponen KTSP}

Tahap kegiatan penyusunan komponen KTSP secara garis besar meliputi: penyiapan dan penyusunan draf, review dan revisi, serta finalisasi, pemantapan dan penilaian. Langkah yang lebih rinci dari masing-masing kegiatan diatur dan diselenggarakan oleh tim penyusun. Namun demikian, pada bagian ini dicontohkan langkah-langkah kegiatan penyusunan dan pengembangan komponen KTSP sebagai berikut.

1) Perumusan dan penetapan visi dan misi sekolah. Dalam perumusan visi dan misi sekolah, peran kepala sekolah sangat penting. Kepala sekolah harus memahami terlebih dahulu potensi sekolah, daya dukung, serta kelemahan-kelemahan dan tantangan yang dihadapinya. Kepala sekolah harus mampu mendayagunakan kekuatan-kekuatan yang relevan bagi kegiatan internal sekolah. Di samping itu, dalam perumusan visi dan misi sekolah, kepala sekolah harus memiliki wawasan kedepan yang akan dicapai.

2) Berdasarkan rumusan visi dan misi sekolah, dirumuskan tujuan pendidikan sekolah. Sekolah harus merumuskan program peningkatan mutu, yang mencakup tujuan pendidikan, sasaran, dan target yang akan dicapai untuk program jangka pendek maupun jangka panjang (rencana strategis). Tujuan pendidikan di tingkat sekolah ini dijadikan sebagai acuan dalam mengembangkan kurikulum.

3) Menyusun struktur dan beban belajar siswa, serta memperhatikan kondisi, karakteristik, dan kebutuhan siswa dan masyarakat setempat.

4) Mengembangkan Silabus. Silabus merupakan bagian integral dari KTSP, sebagai penjabaran dari standar kompetensi dan kompetensi dasar ke dalam materi pelajaran, indikator pencapaian kompetensi, penilaian, dan alokasi waktu serta sumber belajar yang digunakan dalam pembelajaran. Pengembangan silabus dilakukan dengan menganalisis standar kompetensi dan kompetensi dasar. Pengembangan silabus ini dilakukan oleh guru.

5) Menyusun Rencana Pelaksanaan Pembelajaran (RPP), sebagai rencana yang menggambarkan skenario pembelajaran untuk mencapai satu 
kompetensi atau lebih yang ditetapkan dalam standar isi. Dengan demikian, pengembangan dan penyusunan RPP didasarkan pada silabus yang telah dikembangkan.

Penyusunan KTSP merupakan bagian dari kegiatan perencanaan sekolah. Kegiatan ini dapat berbentuk rapat kerja yang diselenggarakan dalam jangka waktu sebelum tahun pelajaran baru. Kegiatan pengembangan KTSP dilakukan oleh tim penyusun kurikulum tingkat satuan pendidikan (sekolah).

Tim penyusun KTSP pada SD, SMP, SMA dan SMK terdiri atas guru, konselor, dan kepala sekolah sebagai ketua merangkap anggota. Dalam kegiatannya, tim penyusun melibatkan komite sekolah, dan nara sumber, serta pihak lain yang terkait. Supervisi dilakukan oleh dinas yang bertanggung jawab di bidang pendidikan tingkat kabupaten/kota untuk SD dan SMP dan tingkat provinsi untuk SMA dan SMK. Dokumen KTSP pada SD, SMP, SMA, dan SMK dinyatakan berlaku oleh kepala sekolah setelah mendapat pertimbangan dari komite sekolah dan diketahui oleh dinas tingkat kabupaten/kota yang bertanggung jawab di bidang pendidikan yang relevan.

Tim penyusun kurikulum tingkat satuan pendidikan MI, MTs, MA dan MAK terdiri atas guru, konselor, dan kepala madrasah sebagai ketua merangkap anggota. Di dalam kegiatan tim penyusun melibatkan komite sekolah, dan nara sumber, serta pihak lain yang terkait. Supervisi dilakukan oleh departemen yang menangani urusan pemerintahan di bidang agama. Dokumen KTSP pada MI, MTs, MA, dan MAK dinyatakan berlaku oleh kepala madrasah setelah mendapat pertimbangan dari komite madrasah dan diketahui oleh departemen yang menangani urusan pemerintahan di bidang agama.

4. Jadwal pelajaran ditingkat satuan pendidikan

Mata pelajaran merupakan materi bahan ajar berdasarkan landasan keilmuan yang akan dibelajarkan kepada peserta didik sebagai beban belajar melalui 
metode dan pendekatan tertentu. Beban belajar pada mata pelajaran ditentukan oleh keluasan dan kedalaman pada tiap-tiap tingkat satuan pendidikan.

Pengertian jadwal menurut Kamus Besar Bahasa Indonesia adalah pembagian waktu berdasarkan rencana pengaturan urutan kerja; daftar atau tabel kegiatan atau rencana kegiatan dengan pembagian waktu pelaksanaan yang terperinci. Sementara Sahertian (1986: 28) menyatakan bahwa jadwal pelajaran di sekolah adalah program kerja (mengajar) guru setiap harisehingga perlu diatur dengan sebaik-baiknya, apabila jumlah siswa terus bertambah, beban mengajar guru juga ikut bertambah.

Jadwal pelajaran berguna untuk mengetahui apa yang akan diajarkan pada suatu waktu dalam suatu kelas. Dari sudut pandang guru, jadwal pelajaran merupakan pedoman di kelas dimana ia harus mengajar pada suatu waktu, dan berapa lama ia harus berada di kelas tersebut, untuk kemudian harus pindah ke kelas lain. Berdasarkan penjelasan tersebut, jadwa pelajaran sebenarnya merupakan penjabaran dari seluruh program pengajaran di sekolah (Suryosubroto, 2010: 44).

Beberapa hal yang harus diperhatikan dalam penyusunan jadwal pelajaran ditingkat satuan pendidikan demi tercapainya tujuan pembelajaran.

1. Antara mata pelajaran satu dengan lainnya harus ada selingan agar tidak menjemukan.

2. Durasi jam pelajaran jangan terlalu lama, untuk kelas I dan II SD satu jam pelajaran 30 menit, kelas III-VI 40 menit, dan untuk sekolah lanjutan 45 menit. Untuk satu mata pelajaran maksimal 2 jam pelajaran jika diberikan berurutan.

3. Tiap-tiap mata pelajaran dicarikan waktu yang sesuai, biasanya mata pelajaran yang banyak membutuhkan daya pikir dijadwalkan pada jam permulaan. Perlu diatur antara mata pelajaran yang memerlukan pemikiran yang banyak atau sebaliknya. Jika memungkinkan, dalam satu hari tidak perlu diisi dengan mata pelajaran kimia, fisika, matematika, atau biologi 
secara berurutan, apalagi disertai dengan adanya mata pelajaran yang membutuhkan tenga lebih seperti olahraga.

4. Harus disediakan waktu istirahat agar peserta didik tidak terlalu lelah.

5. Jangan sampai kegiatan disuatu kelas dapat mengganggu kegiatan di kelas sebelahnya. Untuk itu, perlunya penempatan ruang kelas secara cermat, sebelum membuat jadwal pelajaran sebaiknya dilakukan identifikasi materi dan aktivitas dari tiap-tiap kelas dan mata pelajaran.

6. Untuk sekolah-sekolah yang memiliki kelas atau peserta didik yang sedikit dapat digabung dan diberikan kegiatan yang sama, seperti olahraga dan kesenian.

Depdiknas (2008: 263) menyebutkan prinsip-prinsip dalam membuat jadwal pelajaran sebagai berikut.

1. Sebuah jadwal pelajaran harus berorientasi kepada peserta didik untuk memaksimalkan peluang pembelajaran, ditata sesuai dengan kegiatan yang beragam dan untuk mempertahankan minat dan motivasi peserta didik.

2. Penugasan guru yang paling efisien dan terbaik dapat dicapai apabila organisasi pengajaran sekolah ditentuan dengan baik.

3. Kapasitas untuk menampung jumlah peserta didik di suatu sekolah dikendalikan oleh faktor sarana seperti bangunan. Sebaiknya, semua ruang kelas di dayagunakan sepenuhnya secara produktif.

4. Para guru perlu dijadwalkan untuk mengajar subjek yang sesuai dengan latar pendidikan.

Jadwal pelajaran sangat terkait dengan mata pelajaran sebagai landasan dalam penyusunannya. Mata pelajaran di susun sesuai dengan kurikulum yang berlaku, biasanya terdapat dalam struktur kurikulum. Struktur kurikulum merupakan pola dan susunan mata pelajaran yang harus ditempuh oleh peserta didik dalam kegiatan pembelajaran ke dalam muatan kurikulum setiap 
mata pelajaran pada setiap tahun pendidikan. Muatan kurikulum tersebut dituangkan dalam kompetensi yang harus dikuasai peserta didik sesuai dengan beban belajar yang tercantum dalam struktur kurikulum. 


\section{SOAL}

1. kurikulum operasional yang disusun dan dilaksanakan oleh masingmasing satuan pendidikan, adalah pengertian dari?
a. Kurikulum
b. Kurikulum Tingkat Satuan Pendidikan
c. Kurikulum 2013
d. Kompetensi dasar
e. Kurikulum berbasis kompetensi

2. seperangkat rencana dan pengaturan mengenai tujuan, isi, dan bahan pelajaran, serta cara yang digunakan sebagai pedoman penyelenggaraan kegiatan pembelajaran untuk mencapai tujuan pendidikan tertentu, pengertian kurikulum menurut?
a. Wina Sanjaya $(2009 ; 131)$
b. UU nomor 20 tahun 2003
c. Murray Print (1993)
d. H.A.R Tillar (2002)
e. Hilda Taba (1962)

3. kompetensi adalah perpaduan dari pengetahuan, keterampilan, kemampuan, nilai dan sikap yang direflesikan dalam kebiasaan berfikir dan bertindak.

Pengertian diatas dinyatakan oleh?
a. Wina Sanjaya $(2009 ; 131)$
b. UU nomor 20 tahun 2003
c. Murray Print (1993)
d. H.A.R Tillar (2002)
e. Hilda Taba (1962)

4. Pengertian Kompetensi menurut Sukmadinata (2004) adalah?

a. kualifikasi kemampuan lulusan yang mencakup sikap, pengetahuan, dan keterampilan sesuai dengan standard nasional yang telah disepakati. 
b. kemampuan kerja setiap individu yang mencakup aspek pengetahuan, keterampilan dan sikap kerja yang sesuai dengan standard yang ditetapkan.

c. Kompetensi tidak hanya sekedar mengetahui atau memahami sesuatu tetapi juga menghayatinya dan tercermin dalam pola perilaku seharihari.

d. kompetensi identik dengan life skill yaitu kecakapan, kebiasaan, keterampilan, kegiatan, perbuatan, dan performansi yang dapat diamati dan diukur.

e. Kompetensi merupakan sesuatu yang abstrak.

5. proses dan waktu yang cukup panjang dalam pengembangan kurikulum dibagi menjadi 2, yaitu?
a. Visi dan Misi
b. KTSP dan Kuriukulum 2013
c. Analisis kontenks dan penyusunan komponen KTSP
d. Silabus dan RPP
e. Review dan Revisi

6. Penyusunan Kurikulum Tingkat Satuan Pendidikan mencakup komponen sebagai berikut, kecuali?
a. pengembangan visi dan misi sekolah,
b. perumusan tujuan pendidikan satuan pendidikan,
c. pengembangan dan penyusunan struktur KTSP,
d. penyusunan kalender pendidikan,
e. pengembangan kurikulum.

7. Yang tidak termasuk dengan komponen analisi konteks yang dikembangankan dalam pengembangan KTSP adalah?
a. Menganalisis potensi,
b. Menganalisis kekuatan,
c. Menganalisis kelemahan,
d. Menganalisis masyarakat,
e. Menganalisis peluang 
8. penyiapan dan penyusunan draf, review dan revisi, serta finalisasi, pemantapan dan penilaian adalah Tahap kegiatan peyusunan?
a. KTSP
b. Silabus
c. RPP
d. $\mathrm{KBK}$
e. Kompetensi

9. langkah-langkah kegiatan penyusunan dan pengembangan komponen KTSP sebagai berikut, kecuali?
a. rapat kerja
b. Perumusan dan penetapan visi dan misi sekolah
c. Perumusan tujuan
d. Menyusun struktur
e. Menyusun Rencana Pelaksanaan Pembelajaran (RPP)

10. Berdasarkan rumusan visi dan misi sekolah, dirumuskan tujuan pendidikan sekolah adalah?

a. Sekolah harus merumuskan program peningkatan mutu, yang mencakup tujuan pendidikan, sasaran, dan target yang akan dicapai untuk program jangka pendek maupun jangka panjang (rencana strategis).

b. dapat berbentuk rapat kerja yang diselenggarakan dalam jangka waktu sebelum tahun pelajaran baru.

c. rencana yang menggambarkan skenario pembelajaran untuk mencapai satu kompetensi atau lebih yang ditetapkan dalam standar isi.

d. dengan menganalisis standar kompetensi dan kompetensi dasar. Pengembangan silabus ini dilakukan oleh guru.

e. Tujuan pendidikan di tingkat sekolah ini dijadikan sebagai acuan dalam mengembangkan kurikulum.

\section{ESSAI.}


1. Pengertian kurikulum menurut Menurut UU nomor 20 tahun 2003 ?

2. Penyusunan Kurikulum Tingkat Satuan Pendidikan mencakup komponen?

3. Jelaskan pengertian penyusunan KTSP?

4. Jelaskan 1 bagian dari langkah-langkah kegiatan penyusunan dan pengembangan komponen KTSP?

5. Tim penyusun KTSP pada SD, SMP, SMA dan SMK terdiri atas?

\section{JAWABAN.}

\section{PG}

1. B

2. B

3. A

4. D

5. C

6. $\mathrm{E}$

7. D

8. A

9. A

10. A

\section{ESSAI.}

1. kurikulum adalah seperangkat rencana dan pengaturan mengenai tujuan, isi, dan bahan pelajaran, serta cara yang digunakan sebagai pedoman penyelenggaraan kegiatan pembelajaran untuk mencapai tujuan pendidikan tertentu.

2. a. pengembangan visi dan misi sekolah,

b. perumusan tujuan pendidikan satuan pendidikan,

c. pengembangan dan penyusunan struktur KTSP, 

d. penyusunan kalender pendidikan,
e. pengembangan silabus, dan
f. pengembangan rencana pelaksanaan pembelajaran (RPP).

3. Penyusunan KTSP merupakan bagian dari kegiatan perencanaan sekolah. Kegiatan ini dapat berbentuk rapat kerja yang diselenggarakan dalam jangka waktu sebelum tahun pelajaran baru. Kegiatan pengembangan KTSP dilakukan oleh tim penyusun kurikulum tingkat satuan pendidikan (sekolah).

4. Perumusan dan penetapan visi dan misi sekolah. Dalam perumusan visi dan misi sekolah, peran kepala sekolah sangat penting. Kepala sekolah harus memahami terlebih dahulu potensi sekolah, daya dukung, serta kelemahan-kelemahan dan tantangan yang dihadapinya. Kepala sekolah harus mampu mendayagunakan kekuatan-kekuatan yang relevan bagi kegiatan internal sekolah. Di samping itu, dalam perumusan visi dan misi sekolah, kepala sekolah harus memiliki wawasan kedepan yang akan dicapai.

5. guru, konselor, dan kepala sekolah sebagai ketua merangkap anggota. 


\section{BAB X1II}

\section{MODEL DAN PENGEMBANGAN ORGANISASI KURIKULUM}

\section{A. KOMPETENSI}

Memahami, menerapkan, dan menganalisis model dan organisasi pengembangan kurikulum.

\section{B. TUJUAN}

Mahasiswa memahami model dan organisasi pengembagan kurikulum

\section{MATERI}

1. Pengertian Model daan Pengembangan Organisasi Kurikulum

Model atau konstruksi merupakan ulasan teoritis tentang suatu konsepsi dasar .Dalam pengembangan kurikulum, model dapat merupakan ulasan teoritis tentang suatu proses kurikulum secara menyeluruh atau dapat pula merupakan ulasan tentang salah satu bagian kurikulum.

Model adalah pola-pola penting yang berguna sebagai pedoman untuk melakukan suatu tindakan. Model dapat ditemukan dalam hampir setiap bentuk kegiatan pendidikan, seperti model pengajaran, model adtninistrasi, model evaluasi, model supervisi dan model lainnya. Menggunakan model pada perkembangan kurikulum dapat meningkatkan efisiensi dan produktivitas. Banyak sekolah/fakultas mempunyai rancangan untuk satu tahun, mereka telah memikirkan polanya untuk memecahkan masalah pendidikan atau prosedur yang tidak dapat dihindari, walaupun begitu mereka tidak mempunyai lebel kegiatannya sebagai rancangan.

Menurut Triwiyanto, ( 2015:86 ) perencanaan kurikulum dan pembelajaran terkait dengan fungsi atau proses manajemen kurikulum dan pembelajaran.fungsi atau proses tersebut meliputi perencanaan, pelaksanaan dan evaluasi kurikulum dan pembelajaran. Fungsi atau proses manajemen kurikulum tersebut terkait dengan pengembangan kurikulum dan pembelajaran. Rusman ( 2011:21 ) mengatakan bahwa perencanaan kurikulum sangat tergantung pada pengembangan kurikulum dan tujusn kurikulum yang akan menjadi penghubung teori-teori pendidikan yang digunakan. 
Menurut Soetopo dan Soemanto ( 1993:40 ) manajemen kurikulum dan program pengajaran merupakan bagian dari MBS. Manajemen kurikulum dan program pengajaran mencakup banyak perencanaan, pelaksanaan, dan penlaian kurikulum. Perencanaan dan pengembangan kurikulum nasional pada umumnya telah dilakukan oleh Departemen Pendidikan Nasional pada tingkat pusat. Karena itu level sekolah yang paling penting adalah bagaimana mereaalisasikan dan menyesuaikan kurikulum tersebut dengan kegiatan pembelajaran. Di samping itu, sekolah juga bertugas dan berwewenang untuk mengembangkan kurikulum muatan lokal sesuai dengan kebutuhan masyarakat dan lingkungan setempat.

Organisasi suatu sistem interaksi antar orang yang ditujukan untuk mencapai tujuan organisasi, dimana sistem tersebut memberikan arahan perilaku bagi anggota organisasi. Definisi ini menekan pada keharusannya sebuah organisasi didasarkan pada interaksi sosial diantara anggota dengan lingkungannya supaya tujuan organisasi dapat dicapai secara efektif dan efesien.

Istilah pengembangan menunjukan pada suatu kegiatan menghasilkan suatu alat atau cara yang baru, dimana selama kegiatan tersebut penilaian dan penyempurnaan terhadap alat atau cara tersebut terus dilakukan. Bila setelah mengalami penyempurnaan-penyempurnaan akhirnya alat atau cara tersebut dipandang cukup mantap untuk digunakan seterusnya, maka berakhirlah kegiatan pengembangan tersebut.

Istilah kurikulum digunakan pertama kali pada dunia olahraga pada zaman yunani kuno yang berasal dar kata curir dan curere. Pada waktu itu krikulum diartikan sebagai jarak yang harus ditempuh oleh seorang pelari. Orang mengistilahkannya dengan tempat berpacu atau tempat berlari dari mulai star sampai finish.

Selanjutnya istilah kurikulum digunakan dalam dunia pendidikan. Para ahli pendidikan memiliki penafsiran yang berbeda tentang kurikulum. Namun demikian, dalam penafsiran yang berbeda itu,ada juga kesamaannya. 
Kesamaan tersebut adalah bahwa kurikulum berhubungan erat dengan usaha mengembangkan peserta didik sesuai dengan tujuan yang ingin dicapai.

Kurikulum yaitu dipandang sebagai suatu bahan tertulis yang berisi uraian tentang program pendidikan suatu sekolah yang harus dilaksanakan dari tahun ke tahun.

\section{Model-Model Pengembangan Kurikulum}

Menurut Ruhimat, T. dkk (2009: 74)Model pengembangan kurikulum merupakan suatu alternatif prosedur dalam rangka mendesain (designing), menerapkan (implementation), dan mengevaluasi (evaluation) suatu kurikulum. Oleh karena itu, model pengembangan kurikulum harus dapat menggambarkan suatu proses sistem perencanaan pembelajaran yang dapat memenuhi berbagai kebutuhan dan standar keberhasilan pendidikan.

Model pengembangan kurikulum ini digunakan untuk mengembangkan suatu kurikulum, dimana pengembangan kurikulum dibutuhkan untuk memperbaiki atau menyempurnakan kurikulum yang dibuat untuk dikembangkan sendiri baik dari pemerintah pusat, pemerintah daerah atau sekolah.

\section{a. Model Tyler}

Model Tyler adalah model yang paling dikenal bagi perkembangan kurikulum dengan perhatian khusus pada fase perencanaan, dalam bukunya Basic Principles of Curriculum and Instruction. The Tyler Rationale, suatu proses pemilihan tujuan pendidikan, dikenal luas dan dipraktekkan dalam lingkungan kurikulum. Model pengembangan kurikulum yang dikemukakan :

1) Menentukan Tujuan Pendidikan

Tujuan pendidikan merupakan arah atau sasaran akhir yang harsu dicapai dalam program pendidikan dan pembelajaran. Tujuan pendidikan harus menggambarkan perilaku akhir setelah peserta didik 
mengikuti program pendidikan, sehingga tujuan tersebut harus dirumuskan secara jelas dan terperinci.

Ada tiga aspek yang harus dipertimbangkan sebagai sumber dalam penentuan tujuan pendidikan menurut Tyler, yaitu:

a) hakikat peserta didik,

b) kehidupan masyakat masa kini, dan

c) pandangan para ahli bidang studi.

Penentuan tujuan pendidikan dengan berdasar kepada ketiga aspek diatas, selanjutnya difilter oleh nilai-nilai filosofis masyarakat dan filosofis pendidikan serta psikologi belajar.

2) Menentukan Proses Pembelajaran

Salah satu aspek yang harus diperhatikan dalam penentuan proses pembelajaran adalah persepsi dan latar belakang kemampuan peserta didik. Pengalaman peserta didik akan sangat membantu dalam terwujudnya tujuan pendidikan yang telah ditetapkan. Dalam proses pembelajaran akan terjadi interaksi antara peserta didik dengan lingkungan pendidikan atau sumber belajar, yang tujuannya untuk membentuk sikap, pengetahuan dan keterampilan sehingga muncul perilaku yang utuh.

3) Menentukan Organisasi Pengalaman Belajar

Pengalaman belajar sangat dipengaruhi oleh tahapan-tahapan dan isi atau materi belajar. Tahapan-tahapan belajar yang tersusus dengan rapi akan sangat membantu terwujudnya tujuan pembelajaran. Kejelasan materi dan proses pembelajaran akan memberikan gambaran mengenai jenis evaluasi yang akhirnya dapat digunakan.

4) Menentukan Evaluasi Belajar

Menentukan evaluasi belajar yang cocok merupakan tahap akhir dalam model Tyler. Dalam menentukan evalusi belajar hendaknya mengacu pada tujuan pembelajaran, materi pembelajaran serta proses pembelajaran yang telah ditentukan sebelumnya. Selain itu, hendaknya merujuk pula pada prinsip-prinsip evaluasi yang ada. 
b. Model Taba

Model Taba merupakan modifikasi model Tyler. Modifikasi tersebut penekanannya terutama pada pemusatan perhatian guru. Menurut Taba, guru harus penuh aktif dalam pengembangan kurikulum. Pengembangan kurikulum yang dilakukan guru dan memposisikan guru sebagai innovator dalam pengembang kurikulum merupakan karakteristik dalam model pengembangan Taba. Dalam pengembangannya, model ini lebih bersifat induktif, berbeda dengan model tradisional yang deduktif. Langkah-langkahnya adalah sebagai berikut:

1) Mengadakan unit-unit eksperimen bersama dengan guru-guru.

2) Menguji unit eksperimen.

3) Mengadakan revisi dan konsolidasi

4) Pengembangan keseluruhan kurikulum (developing' a framework).

5) Implementasi dan desiminasi.

c. Model Administratif

Pengembangan kurikulum ini disebut juga dengan istilah dari atas ke bawah (top down) atau staff lini (line-staff procedure), artinya dalam pengembangan kurikulum ini terdapat beberapa tahapan secara prosedural yang harus ditempuh dengan dibantu oleh beberapa tim tertentu. Langkah pertama adalah pembentukan ide awal yang dilaksanakan oleh para pejabat tingkat atas, yang membuat keputusan dan kebijakan berkaitan dengan pengembangagn kurikulum Tim ini sekaligus sebagai tim pengarah dalam pengembangan kurikulum.

Langkah kedua adalah membentuk suatu tim panitia pelaksana atau komisi untuk mengembangkan kurikulum yang didukung oleh beberapa anggota yang terdiri dari para ahli. Tim ini bertugas untuk mengembangkan konsep-konsep umum, landasan, rujukan, maupun strategi pengembangan kurikulum yang selanjutnya menyusun kurikulum secara opersional berkaitan dengan pengembangan atau perumusan tujuan pendidikan maupun pembelajaran. 
Langkah ketiga, kurikulum yang sudah selesai disusun kemudia diajukan untuk diperiksa dan diperbaiki oleh tim pengarah. Tim ini melakukan penyesuaian antara aspek-aspek kurikulum secara terkoordinasi dan menyiapkan secara sistem dalam rangka uji coba maupun dalam rangka sosialisasi dan penyebarluasan (desiminasi). Pelaksana uji coba adalah tenaga professional yang tidak dilibatkan dalam penyusunan kurikulum.

Supaya uji coba tersebut menghasilkan masukan yang efektif maka diperlukan kegiatan monitoring dan evaluasi yang fungsinya untuk memperbaiki atau menyempurnakan berdasarkan pelaksanaan di lapangan.

d. Model Nicholls

Dalam bukunya Developing a Curriculum: a Practical Guide (1978), Howard Nicholls menjelaskan bahwa pendekatan pengembangan kurikulum terdiri atas elemen-elemen kurikulum yang membentuk siklus. Model pengembangan kurikulum Nicholls menggunakan pendekatan siklus seperti model Wheeler. Model Nicholls digunakan apabila ingin menyusun kurikulum baru yang diakibatkan oleh terjadinya perubahan situasi.Ada lima langkah pengembangan kurikulum menurut Nicholls, yaitu:

1) Analisis sesuatu

2) Menentukan tujuan khusus

3) Menentukan dan mengorganisasi isi pelajaran

4) Menentukan dan mengorganisasi metode

5) Evaluasi

e. Model Dynamic Skilbeck

Menurut Skilbeck, model pengembangan kurikulum yang ia namakan model Dynamic, adalah model pngembangan kurikulum pada level sekolah (School Nased Curriculum Development). Skilbeck menjelaskan model ini diperuntukkan untuk setiap guru yang ingin mengembangkan kurikulum yang sesuai dengan kebutuhan sekolah. Agar 
proses pengembangan berjalan dengan baik, maka setiap pengembang termasuk guru perlu memahami lima elemen pokok yang dimulai dari mennganalisis situasi sampai pada melakukan penilaian. Skilbeck menganjurkan model pengembangan kurikulum yang ia susun dapat dijadikan alternative dalam pengembangan kurikulum tingkat sekolah. Menurut Skilbeck langkahlangakah pengembangan kurikulum adalah sebagai berikut:

1) Menganalisis sesuatu

2) Memformulasikan tujuan

3) Menyususn program

4) Interpretasi dan implementasi

5) Monitoring, feedback, penilaian, rekonstruksi

f. Model Saylor, Alexander, Dan Lewis

Model ini membentuk curriculum planning process (proses perencanaan kurikulum). Untuk mengerti model ini, kita harus menganalisa konsep kurikulum dan konsep rencana kurikulum mereka. Kurikulum menurut mereka adalah "a plan for providing sets of learning opportunities for persons to be educated" ; sebuah rencana yang menyediakan kesempatan belajar bagi orang yang akan dididik. Namun, rencana kurikulum tidak dapat dimengerti sebagai sebuah dokumen tetapi lebih sebagai beberapa rencana yang lebih kecil untuk porsi atau bagian kurikulum tertentu.

\section{Organisasi Kurikulum}

Menurut Ruhimat, T. dkk,(2009: 83). Organisasi kurikulum merupakan pola atau desain bahan/ isi kurikulum yang tujuannya untuk mempermudah siswa dalam mempelajari bahan pelajaran serta mempermudah siswa dalam melakukan kegiatan belajar, sehingga tujuan pengembangan dapat dicapai secara efektif.

Salah satu aspek yang perlu dipahami dalam pengembangan kurikulum adalah aspek yang berkaitan dengan organisasi kurikulum. Organisasi 
kurikulum berkaitan dengan pengaturan bahan pelajaran, yang selanjutnya memiliki dampak terhadap masalah administrative pelaksanaan proses pembelajaran, team teaching misalnya.

a. Organisasi Kurikulum Berdasarkan Mata Pelajaran (Subjet Curriculum)

Organisai kurikulum berdasarkan mata pelajaran dibedakan atas empat pola yaitu Separated Curriculum, Boradfield Curriculum, dan Integrated Curriculum :

1) Mata Pelajaran Terpisah (Separated Curriculum)

Bentuk kurikulum ini sudah lama digunakan, karena organisasi kurikulum bentuk ini sederhana dan mudah dilaksanakan. Tetapi tidak selamanya yang dianggap mudah dan sederhana tersebut akan mendukung terhadap efektivitas dan efisiensi pendidikan yang sesuai dengan perkembangan sosial.

2) Mata Pelajaran Korelsi (CorrelatedCurriculum)

Pola kurikulum korelasi yaitu pola organisasi kurikulum yang menghubungkan pembahasan suatu mata pelajaran dengan mata pelajaran lainnya, atau suatu pokok bahasan dengan pokok bahasan lainnya. Materi kurikulum yang terlepas-lepas diupayakan dihubungkan dengn materi kurikulum atau materi pelajaran yang sejenis atau relevan dengan tujuan pembelajaran, sehingga dapat memperkata wawasan siswa.

3) Fusi Mata Pelajaran (Broadfields Curriculum)

Fusi mata pelajaran atau dikenal juga dengan istilah broadfields curriculum adalah jenis organisasi kurikulum yang menghapuskan batasbatas mata pelajaran dan menyatukan mata pelajaran yang memiliki hubungan erat dalam satu kesatuan, tujuannya adalah agar para pendidik mengerti jenis-jenis arti perkembangan kebudayaan yang efektif, manfaat yang didapat dari berbagai ragam disiplin ilmu, dan upaya mendidik anak agar menghasilkan anak yang civilled Ruhimat, T. dkk, (2009: 87). Beberapa disiplin ilmu sejenis disatukan dalam satu mata pelajaran tertentu.

4) Kurikulum Terpadu 
Kurikulum ini memandang bahwa dalam suatu pokok bahasan harus terpadu (integrasi) secara menyeluruh. Keterpaduan ini dapat dicapai melalui pemusatan pelajaran pada satu masalah tertentu dengan alternative pemecahan melalui berbagai disiplin ilmu atau mata pelajaran yang diperlukan, sehinbgga batas-batas antar mata pelajaran dapat ditiadakan. 15 Pembelajaran yang mungkin digunakan adalah pemecahan masalah, metode proyek, pengajaran unit, inkuiri, dicovery, dan oendekatan tematik yang dilakukan dalam pembelajaran kelompok maupun secara perorangan. Pengembangan program pembelajran perlu dilakukan secara bersamasama antara siswa dan guru, tetapi sebelumnya guru harus menyiapkan rancangan program pembelajaran sebagai acuan yang perlu dikembangkan bersama-sama dengan siswa atau mungkin dengan masyarakat.

Beberapa bentuk organisasi kurikulum dalam kategori ini diantaranya:

a) Kurikulum Inti (Core Curriculum)

b) Social Function dan Persistent Situations

Kurikulum ini didasarkan atas analisis kegiatan-kegiatan manusia dalam masyarakat, dalam social function ini dapat diangkat berbagai kegiatan-kegiatan manusia yang dapat dijadikan sebagai topic pembelajaran. Sebagai modifikasi dari social function adalah persistent life situations, kajian substansi dalam kurikulum bentuk ini lebih mendalam dan terarah. Karakteristiknya adalah situasi yang diangkat senantiasa yang dihadapi manusia dalam hidupnya, masa lalu, saat ini, dan masa yang akan dating.

c) Experience atau Activity Curriculum

Kurikulum ini cenderung mengutamakan kegiatan-kegiatan atau pengalaman-pengalaman siswa dalam rangka membentuk kemampuan yang terintegrasi dengan lingkungan maupun dengan potensi siswa.

Ada empat tipe pembelajaran proyek yang dapat dikembangkan dalam activity curriculum, diantaranya: 
(1) Construction on creative project. Pembelajaran ini bertujuan untuk mengembanglan ide-ide atau merealisasikan suatu ide dalam suatu bentuk tertentu.

(2) Appreciation on enjoyment project. Pembelajaran ini bertujuan menikmati pengalaman pengalaman dalam bentuk apreasi atau estetis atau estetika.

(3) The problem project. Pembelajaran ini bertujuan untuk memecahkan masalah yang bersifat intelektual tetapi ada subtansi keterampilannya (vokasional).

(4) The drill or specific project. Pembelajaran ini bertujuan untuk memperoleh beberapa item atau tingkat keterampilan.

b. Kurikulum tingkat satuan pendidikan

Kurikulum ini dikatakan sebagai perbaikan dari KBK yang diberi nama Kurikulum Tingkat Satuan Pendidikan (KTSP). KTSP ini merupakan bentuk implementasi dari UU No. 20 tahun 2003 tentang sistem pendidikan nasional yang dijabarkan ke dalam sejumlah peraturan antara lain Peraturan Pemerintah Nomor 19 tahun 2005 tentang standar nasional pendidikan. Peraturan Pemerintah ini memberikan arahan tentang perlunya disusun dan dilaksanakan delapan standar nasional pendidikan, yaitu:

1) Standar isi,

2) Standar proses,

3) Standar kompetensi lulusan,

4) Standar pendidik dan tenaga kependidikan,

5) Standar sarana dan prasarana,

6) Standar pengelolaan, standar pembiayaan, dan

7) Standar penilaian pendidikan.

Terdapat perbedaan mendasar dibandingkan dengan KBK tahun 2004 dengan KBK tahun 2006 (versi KTSP), bahwa sekolah diberi kewenangan penuh dalam menyusun rencana pendidikannya dengan mengacu pada standar-standar yang ditetapkan, mulai dari tujuan, visi-misi, struktur dan 
muatan kurikulum, beban belajar, kalender pendidikan hingga pengembangan silabusnya Kurikulum Tingkat Satuan Pendidikan (KTSP) merupakan sebuah kurikulum operasional yang disusun oleh guru di setiap tingkatan satuan pendidikan berdasarkan kebutuhannya. Kurikulum ini dikembangkan atas dasar perbedaan karakteristik dari setiap tingkat satuan pendidikan. 


\section{SOAL PILIHAN GANDA dan ESSAY}

\section{PILIHAN GANDA}

1. Menurut (Ruhimat, T. dkk 2009: 74)Model pengembangan kurikulum merupakan suatu alternatif prosedur? kecuali..
a. Mengevaluasi
c.Menerapkan
b. Mendisain
d. Menulis

2. Apa saja model perkembangan kuikulum?kecuali...
a. Model Tyler
c. ModeDemostrasi
b. Model Taba
d. ModelNicholls

3. Pengembangan kurikulum ini disebut juga dengan istilah dari atas ke bawah (top down) atau staff lini (line-staff procedure),model menurut?
a. Model Adminsitratif
c. ModelTyler
b. Model Taba
d. ModelNicholls

4. Aspek yang harus dipertimbangkan sebagai sumber dalam penentuan tujuan pendidikan menurut Tyler,kecuali?
a. hakikat peserta didik
b. pandangan para ahli bidang studi
c. kehidupan masyakat masa kini
d. Menentukanproses pembelajaran

5. (1)Menguji unit eksperimen.

(2)Mengadakan revisi dan konsolidasi

(3)Mengadakan unit-unit eksperimen bersama dengan guru-guru.

(4)Implementasi dan desiminasi

(5)Pengembangan keseluruhan kurikulum (developing' a framework).

Dari langkah-langkah diatas urutkan dengan benar?
a. $1,2,3,4,5$
c. $2,4,5,3,1$
b. $3,1,2,5,4$
d. $1,3,5,4,2$

6. Pengembangan kurikulum yang dilakukan guru dan memposisikan guru sebagai innovator dalam pengembang kurikulum merupakan karakteristik dalam model?
a. Model Taba
c.ModelSaylor
b. Model Dynamic Skilbeck
d. Model Tyler

7. Analisis sesuatu, menentukan tujuan khusus, menentukan dan mengorganisasi isi pelajaran, menentukan dan organisasi metode, evaluasi. Dari langkah-langkah tersebut menurut model? 

a. Dynamic Skilbeck
c. Tyler
b. Taba
d. Nicholls

8. Organisai kurikulum berdasarkan mata pelajaran dibedakan atas...pola?
a. 1
c. 3
b. 2
d. 4

9. 15 Pembelajaran yang mungkin digunakan adalah pemecahan masalah, metode proyek, pengajaran unit, inkuiri, dicovery, dan oendekatan tematik yang dilakukan dalam pembelajaran kelompok maupun secara perorangan. Salah satu pengertian dari?

a. Kurikulum Terpadu

b. MataPelajaran Terhubung

c. Fusi Mata Pelajaran

d. MataPelajaran Terpisah

10. a) standar isi

b) standar sarana dan prasarana,

c) standar proses,

d) standar kompetensi lulusan,

e) standar penilaian pendidikan.

f) standar pendidik dan tenaga kependidikan,

g) standar pengelolaan, standar pembiayaan,

Peraturan Pemerintah ini memberikan arahan tentang perlunya disusun dan dilaksanakan delapan standar nasional pendidikan. Susunan yang benar adalah?
a. a,b,c,d,e,f,g
b. c. a,c,d,f,b,g,e
c. b,c,d,a,e,g,f
d. d. g,f,e,d,c,b,a

JAWABAN

1. D

6. A

2. $\mathrm{C}$

7. D

3. A

8. A

4. D

9. A

5. B

10. C

\section{ESSAY}


1. Jelaskan pengertian Model Tyler?

2. Jelskan dari arti menentukan tujuan pendidikan?

3. Jelaskan langkah kedua dari model administratif ?

4. Sebutkan Organisasi Kurikulum Berdasarkan Mata Pelajaran?

5. Sebutkan empat tipe pembelajaran proyek yang dapat dikembangkan dalam activity curriculum ?

\section{JAWABAN}

1. Model Tyler adalah model yang paling dikenal bagi perkembangan kurikulum dengan perhatian khusus pada fase perencanaan, dalam bukunya Basic Principles of Curriculum and Instruction. The Tyler Rationale, suatu proses pemilihan tujuan pendidikan, dikenal luas dan dipraktekkan dalam lingkungan kurikulum.

2. Tujuan pendidikan merupakan arah atau sasaran akhir yang harsu dicapai dalam program pendidikan dan pembelajaran. Tujuan pendidikan harus menggambarkan perilaku akhir setelah peserta didik mengikuti program pendidikan, sehingga tujuan tersebut harus dirumuskan secara jelas dan terperinci.

3. Langkah kedua adalah membentuk suatu tim panitia pelaksana atau komisi untuk mengembangkan kurikulum yang didukung oleh beberapa anggota yang terdiri dari para ahli.

4. Mata pelajaran terpisah, mata pelajaran terhubung, fusi mata pelajara, kurikulum pelajaran.

5. (1) Construction on creative project. Pembelajaran ini bertujuan untuk mengembanglan ideide atau merealisasikan suatu ide dalam suatu bentuk tertentu.

(2) Appreciation on enjoyment project. Pembelajaran ini bertujuan menikmati pengalaman pengalaman dalam bentuk apreasi atau estetis atau estetika.

(3) The problem project. Pembelajaran ini bertujuan untuk memecahkan masalah yang bersifat intelektual tetapi ada subtansi keterampilannya (vokasional).

(4) The drill or specific project. Pembelajaran ini bertujuan untuk memperoleh beberapa item atau tingkat keterampilan. 


\section{BAB X1V}

\section{PERANAN DAN APLIKASI IT DALAM MANAJEMEN KURIKULUM DAN ANALISIS KASUS DALAM MANAJEMEN KURIKULUM}

A. KOMPETENSI :Peranan dan aplikasi IT dalam manajemen kurikulum dan analisis kasus dalam manajemen kurikulum.

B. TUJUAN : Mahasiswa memahami Peranan dan aplikasi IT dalam manajemen kurikulum

C. MATERI :

Menrurut Alter, Martin dan Lucas dalam Abdul Kadir (2003:13), teknologi inforasi mencakup perangkat keras dan perangkat lunak untuk melaksanakan satu atau sejumlah tugas pemrosesan data seperti mnangkap , mentransmisikan , menyimpan, mengambil, memanipulasi atau menampilkan data.

Sementara menuru wawan wardiana (200:34) mengemukakan bahwa teknologi informsi adalah suatu teknologi yang digunakan untuk mengolah data, termasuk memproses, mendapatkan, menyusun, menyimpan, memanipulasi data berbagai cara untuk menghasilkan informasi yang berkualitas, yaitu informasi yang relevan, akurat dan tepat waktu, yag digunakan untuk keperluan pribadi, bisnis, dan pemerintahan yang merupakan aspek strategis untuk pengambilan keputusan.

Menurut Abdul Kodir (2003:14) bahwa teknologi informasi digolongkan mejadi 2 , yaitu perangkat lunak (software) dan perangkat keras (hardware). Perangkat keras menyangkut pada peralatan yang bersifat fisik, seperti memory, printer, juga keyboard. Sedangkan perangkat lunak terkait dengan intruksi untuk mengatur perangkat keras agar bekerja sesuai dengan itruksi tersebut.

\section{Peran IT dalam Implementasi Kurikulum}

Ilmu pengetahuan merupakan usaha manusia untuk memahami gejala dan fakta alam, dan melestarikan pengetahuan tersebut secara konsepsional dan sistematis. Sedangkan teknologi adalah usaha manusia untuk memanfaatkan ilmu pengetahuan itu untuk kepentingan dan kesejahteraan. Karena hubungan tersebut maka perkembangan ilmu pengetahuan selalu terkait dengan perkembangan teknologi, demikian pula sebaliknya. Perkembangan ilmu pengetahuan dan teknologi 
mempunyai ciri eksponensial yaitu semakin lama semakin cepat, karena hasil dari suatu tahap menjadi dasar dan alasan bagi tahap selanjutnya.

Proses dan produk teknologi yang dihasilkan, tidak semuanya dapat dimanfaatkan dan secara relevan dapat dimanfaatkan untuk pendidikan terutama untuk proses dan hasil pembelajaran. Teknologi informasi menekankan pada pelaksanaan dan pemprosesan data seperti menangkap, mentransmisikan, menyimpan, mengambil, memanifulasi atau menampilkan data dengan menggunakan perangkat-perangkat teknologi elektronik terutama komputer. Makna teknologi informasi tersebut belum menggambarkan secara langsung kaitannya dengan sistem komunikasi, namum lebih pada pengolahan data dan informasi. Sedangkan teknologi komunikasi menekankan pada penggunaan perangkat teknologi elektronika yang lebih menekankan pada aspek ketercapaian tujuan dalam proses komunikasi, sehingga data dan informasi yang diolah dengan teknologi informasi harus memenuhi kriteria komunikasi yang efektif.

Teknologi informasi dan komunikasi (tik) memilliki tiga fungsi utama yang berkaitan dengan kurikulum, yaitu :

a. teknologi berfungsi sebagai alat (tools)

Dalam hal ini tik digunakan sebagai alat bantu bagi pengguna (user) atau siswa untuk membantu pembelajaran, misalnya dalam mengolah kata, mengolah angka, membuat unsur grafis, membuat database, membuat program administratif untuk siswa, guru dan staf, data kepegawaian, keungan dan sebagainya.

b. teknologi berfungsi sebagai ilmu pengetahuan (science)

Dalam hal ini teknologi sebagai bagian dari disiplin ilmu yang harus dikuasai oleh siswa. Misalnya teknologi komputer dipelajari oleh beberapa jurusan di perguruan tinggi seperti informatika, manajemen informasi, ilmu komputer. Dalam pembelajaran di sekolah sesuai kurikulum 2006 terdapat mata pelajaran tik sebagai ilmu pengetahuan yang harus dikuasi siswa semua kompetensinya.

c. teknologi berfungsi sebagai bahan dan alat bantu untuk pembelajaran (literacy).

Dalam hal ini teknologi dimaknai sebagai bahan pembelajaran sekaligus sebagai alat bantu untuk menguasai sebuah kompetensi berbantuan komputer. Dalam hal ini komputer telah diprogram sedemikian 
rupa sehingga siswa dibimbing secara bertahap dengan menggunakan prinsip pembelajaran tuntas untuk menguasai kompetensi.

Dalam hal ini posisi teknologi tidak ubahnya sebagai guru yang berfungsi sebagai :

1) fasilitator

2) motivator

3) transmiter

4) evaluator.

Sebagai bagian dari pembelajaran, teknologi / TI memiliki tiga kedudukan, yaitu :

a) Peran tambahan (suplemen)

Dikatakan berfungsi sebagai suplemen (tambahan), apabila peserta didik mempunyai kebebasan memilih, apakah akan memanfaatkan materi pembelajaran melalui TI atau tidak. Dalam hal ini, tidak ada kewajiban/keharusan bagi peserta didik untuk mengakses materi pembelajaran melalui TI. Sekalipun sifatnya hanya opsional, peserta didik yang memanfaatkannya tentu akan memiliki tambahan pengetahuan atau wawasan. Walaupun materi pembelajaran melalui TI berperan sebagai suplemen, para dosen /guru tentunya akan senantiasa mendorong, mengggugah, atau menganjurkan para peserta didiknya untuk mengakses materi pembelajaran melalui ti yang telah disediakan.

b) Fungsi pelengkap (komplemen)

Dikatakan berfungsi sebagai komplemen (pelengkap), apabila materi pembelajaran melalui TI diprogramkan untuk melengkapi materi pembelajaran yang diterima peserta didik di dalam kelas. Sebagai komplemen berarti materi pembelajaran melalui TI diprogramkan untuk menjadi materi reinforcement (pengayaan) yang bersifat enrichment atau remedial bagi peserta didik di dalam mengikuti kegiatan pembelajaran konvensional.

c) Fungsi pengganti (substitusi)

Beberapa perguruan tinggi di negara-negara maju memberikan beberapa alternatif model kegiatan pembelajaran/perkuliahan kepada 
para mahasiswanya. Tujuannya adalah untuk membantu mempermudah para maasiswa mengelola kegiatan pembelajaran/ perkuliahannya sehingga para mahasiswa dapat menyesuaikan waktu dan aktivitas lainnya dengan kegiatan perkuliahannya. Sehubungan dengan hal ini, ada 3 alternatif model kegiatan pembelajaran yang dapat dipilih para mahasiswa, yaitu apakah mereka akan mengikuti kegiatan pembelajaran yang disajikan secara konvensional (tatap muka) saja, atau sebagian secara tatap muka dan sebagian lagi melalui internet, atau bahkan sepenuhnya melalui internet. Alternatif model pembelajaran manapun yang akan dipilih oleh para mahasiswa tidak menjadi masalah dalam penilaian. Artinya, setiap mahasiswa yang mengikuti salah satu model penyajian materi perkuliahan akan mendapatkan pengakuan atau penilaian yang sama. Jika mahasiswa dapat menyelesaikan program perkuliahannya dan lulus melalui cara konvensional atau sepenuhnya melalui internet, atau bahkan melalui perpaduan kedua model ini, maka institusi penyelenggara pendidikan akan memberikan pengakuan yang sama. Keadaan yang sangat fleksibel ini dinilai sangat membantu para mahasiswa untuk mempercepat penyelesaian perkuliahannya. Para mahasiswa yang belajar pada lembaga pendidikan konvensional tidak perlu terlalu khawatir lagi apabila tidak dapat menghadiri kegiatan perkuliahan secara fisik karena berbenturan dengan kepentingan lain yang tidak dapat ditinggalkan atau ditangguhkan. Apabila lembaga pendidikan konvensional tersebut menyajikan materi pembelajaran yang dapat diakses para mahasiswa melalui internet, maka mahasiswa dapat mempelajari materi perkuliahan yang terlewatkan tersebut melalui internet. Dapat terjadi demikian karena para mahasiswa diberi kebebasan mengikuti kegiatan perkuliahan yang sebagian disajikan secara tatap muka dan sebagian lagi melalui internet (model pembelajaran kedua). Di samping itu, para mahasiswa juga dimungkinkan untuk tidak sepenuhnya menghadiri kegiatan perkuliahan secara fisik. Sebagai penggantinya, para mahasiswa belajar melalui internet (model pembelajaran ketiga). 


\section{Analisis Kasus Dalam Manajemen Kurikulum}

Manajemen kurikulum dan pembelajaran diarahkan agar proses pembelajaran sesuai dengan tujuan yang telah dirumuskan . Guru diberikan kewenangan untuk mengembangkan kurikulum agar proses belajar mengajar memiliki makna yang mendalam pada diri siswa dan guru. Kepala sekolah juga bertanggung jawab dalam membimbing dan mengarahkan pengembangan kurikulum dan pembelajaran serta melakukan supervi dalam pelaksanaannya. Untuk ketercapaian program kurikulum dan pembelajaran yang efektif, kepala sekolah beserta guru harus menjabarkan isi kurikulum secara lebih rinci dan operasional kedalam program tahunan, catur wulan dan bulanan. Agar proses belajar mengajar berjalan sesuai tujuan yang telah ditetaopkan, maka langkah-langkah dalam pelaksanaan kurikulum disekolah perlu diperhatikan. Tahapan pelaksanaan kurikulum diskeolah melalui 4 tahap yaiu :

a. Tahap Perencanaan

Pada tahap ini perlu dijabarkan menjadi Rencana Pembelajaran (RP). Guru melakukan persiapan yang komprehensif sebelum melakukan proses belajar mengajar dikelas. Pada tahap ini guru melakukan pesiapan dari mulai tujuan pembelajaran, materi yang akan disampaikan, metode yang tepat yang akan digunakan, media dan alat yang mendukung proses pembelajaran, buku atau sumber referensi, dan alat evaluasi yang akan diterapkan. Dalam tahap perencanaan ini pula perlu dipahami hal-hal sebagai berikut: menjabarkan GBPP menjadi Analisis Mata pelajaran (AMP), memiliki kalendr akademik, menyusun program tahunan (Prota), menyusun program catur wulan (Proca), Program Satuan Pembelajaran (PSP), Rencana Pengajaran (RP).

b. Tahap Pengorganisasian dan Koordinasi

Pada tahap prencanaan seluruh aspek yang berkaitan dengan proses pembelajaran disiapkan secara matang dan menyeluruh agar pada tahap pengorganisasian dan koordinasi dapat dilaksanakan dengan sebaik-baiknya. Pada tahap pengorganisasian dan koordinasi ini merupakan tahap yang perlu diperhatikan secara sunggug-sungguh oleh kepala sekolah beserta tim yang dibentuk untuk memudahkan pembagian tugas sesuai dengan kegiatan yang akan dilaksanakan.

c. Tahap Pelaksanaan

Pada tahap ini merupakan tahap yang peling menentukan apakah sekolah dibawah kepemimpinan kepala sekolah dapat mewujudkan program sekolah 
atau tidak. Perencanaan, pengorganisasian dan koordinasi yang telah disusun akan dibutikan keberhasilannya dalam tahap pelaksanaan ini. Proses belajar mengajar akan berjalan secara efektif apabila guru dan kepala sekolah memiliki tanggung jawab dalam upaya meningkatkan mutu pembelajaran. Mutu pembelajaran dapat dilaksanakan dengan baik apabila guru dan kepala sekolah bersama-sama untuk membuka diri terhadap masukan atau kritikan yang membangun. Sebagai guru harus siap diberi masukan oleh kepala sekolah berdasarkan hasil supervisi yang dilakukan oleh kepala sekolah. Begitupun kepala sekolah harus memiliki jadwal yang jelas dan rinci untuk melakukan supervisi terhadap kinerja guru. Hasil supervisi kepala sekolah menjadi fakta dan data yang benar untuk memberikan informasi kepada guru berkaitan dengan tugas yag di kerjakannya selama di sekolah. Apabila kepala sekolah memiliki fakta dan data yang berkaitan dengan kinerja guru maka guru akan meerima dengan terbuka terhadap masukan yang disampaikan oleh kepala sekolah. Sebaliknya apabila kepala sekolah tidak melakuka supervisi (tidak berdasarkan fakta dan data) yang diperoleh langsung oleh kepala sekolah, maka masukan yang diberikan oleh kepala sekolah tidak valid dan berpengaruh negative terhadap kinerja guru. Dengan demikian, kepala sekolah dan guru akan terbuka dalam memberikan masukan atau kesulitaan yang dihadapi dengan tujuan untuk kemajuan dan peingkatan mutu pembelajaran.

d. Tahap Evaluasi dan pengendalian

Pelaksanaan pembelajaran berjalan secara efektif atau tidak dapat diketahui mulalui kegiatan evaluasi. Evaluasi ini penting dlakukan secara benar karena bertujuan untuk mengetahui apakah tujuan pembelajaran yang telah dilakukan berjalan atau tidak sesuai dengan rencana yang telah ditetapkan. Guru perlu menetapkan jenis evaluasi apa yang digunakan dan hasil evaluasi diharapkan akan memiliki pengaruh dan dampak terhadap perbaikan dan peningkatan mutu pembelajaran selanjutnya. Dengan diadakannya evaluasi ini akan memberikan dampak dan manfaat bagi guru dan siswa untuk peningkatan mutu pendidikan secara berkelanjutan. Dengan demikian evaluasi juga dapat menjadi umpan balik bagi guru untuk memperbaiki proses pembelajaran selanjutnya. 


\section{SOAL}

PG

1. Teknologi informasi adalah seperangkat alat yang membantu anda bekerja dengan informasi dan melakukan tugas-tugas yang berhubungan dengan pemrosesan informasi. Definisi tersebut dikemukakan oleh ...
a. Rusman
b. Teguh
c. Hag dan Keen
d. Keen dan Teguh

2. pengertian teknologi informasi adalah teknologi yang menggabungkan komputasi (komputer) dengan jalur komunikasi kecepatan tinggi yang membawa data, suara, dan video. Definisi tersebut dikemukakan oleh...
a. Williams dan Sawyer
b. Haag dan Keen
c. Sawyer
d. Williams

3. Yang merupakan tahap paling menentukan apakah sekolah dibawah kepemimpinan kepala sekolah dapat mewujudkan program sekolah atau tidak adalah ...
a. Tahap Pelaksanaan
b. Tahap Evaluasi
c. Tahap perencanaan
d. Tehap pengendalian

4. Guru perlu menetapkan jenis evaluasi apa yang digunakan dan hasil evaluasi diharapkan akan memiliki pengaruh dan dampak terhadap perbaikan dan peningkatan mutu pembelajaran selanjutnya. Masuk kedalam tahapan...
a. Tahap pelaksanaan
b. Tahap perencanaaan
c. Tahap ealuasi
d. Tahap evaluasi dan pengedalian

5. teknologi informasi merupakan teknologi yang tidak hanya pada teknologi komputer (perangkat keras dan perangkat lunak) yang akan digunakan untuk 
memproses dan menyimpan informasi, melainkan mencaku teknologi komunikasi untuk mengirim atau menyebarluaskan informasi. Adalah pengertian menurut...
a. Williams
b. Martin
c. Sawyer
d. Hamalik

6. teknologi berfungsi sebagai bahan dan alat bantu untuk pembelajaran. Atau biasa disebut...
a. komplemen
b. literacy
c. implement
d. tahapan

7. Dalam hal ini tik digunakan sebagai alat bantu bagi pengguna (user) atau siswa untuk membantu pembelajaran, misalnya dalam mengolah kata, mengolah angka, membuat unsur grafis, membuat database, membuat program administratif untuk siswa, guru dan staf, data kepegawaian, keungan dan sebagainya. Termasuk kedalam pengertian ...
a. tscience
b. tools
c. tahapan
d. literacy

8. untuk memperoleh hasil yang diharapkan dalam kegiatan manajemen kuikulum perlu adanya kerjasama yang positif dari berbagai pihak yang terlibat. Berikut adalah prinsip dari...
a. efektivitas
b. kooperatif
c. produktivitas
d. efesiensi

9. suatu sistem pengelolaan kurikulum yang kooperatif, komperhensif, sistemik dan sistematik dalam rangka mewujudkan ketercapaian tujuan kurikulum. Merupakan definisi...

6. Manajemen

7. Kurikulum

8. Manajemen kurikulum 


\section{Peraturan}

10. Pelaksanaan manajemen kurikulum harus berasaskan pada demokrasi yang menempatkan pengelola, pelaksana dan subjek didik pada posisi yang seharusnya dalam melakasanakan ugas dengan penuh tanggung jawab untuk mencapai tujuan krikulum. Termasuk kedalam prinsip...
a. Produktivitas
b. Demokratis
c. Kooperatif
d. Evektifitas

\section{ESSAY}

1. Apa yang dimaksud dengan IT ?

2. Jelaskan pengertian Teknologi Informasi menurut Williams dan Sawyer (2003) !

3. Sebutkan fungsi utama yang berkaitan dengan kurikulum ?

4. Jelaskan tahapan pengorganisasian dan koordinasi !

5. Sebutkan tahapan apa saja yang dibuat untuk kurikulum sekolah ?

Jawaban:

I. $\mathrm{PG}$

1. $\mathrm{C}$

2. A

3. A

4. D

5. B

6. B

7. $\mathrm{B}$

8. B

9. $\mathrm{C}$

10. B

\section{ESSAY}


1. suatu studi perancangan, implementasi, pengembangan, dukungan atau manajemen sistem informasi berbasis komputer, terutama pada aplikasi hardware (perangkat keras) dan software (perangkat lunak komputer).

2. teknologi yang menggabungkan komputasi (komputer) dengan jalur komunikasi kecepatan tinggi yang membawa data, suara, dan video.

3. a. Teknologi berfungsi sebagai alat (tools)

b. Teknologi berfungsi sebagai ilmu pengetahuan (science)

c. Teknologi berfungsi sebagai bahan dan alat bantu untuk pembelajaran (literacy).

4. Pada tahap prencanaan seluruh aspek yang berkaitan dengan proses pembelajaran disiapkan secara matang dan menyeluruh agar pada tahap pengorganisasian dan koordinasi dapat dilaksanakan dengan sebaik-baiknya

5. a. Tahap perencanaan

b. Tahap pengorganisasian dan koordinasi

c. Tahap peaksanaan

d. Tahap pengendalian 


\section{DAFTAR PUSTAKA}

Arsyad, dan Sulfemi, Wahyu Bagja. (2014). Minat Siswa Tentang Keadministrasian dengan Hasil Belajar Administrasi Perkantoran. Edutecno. 9 (2), 40-50.

Badar, Dadan Samsul dan Sulfemi, Wahyu Bagja. (2014). Pengaruh Rasa Percaya Diri dan Motivasi Berprestasi Terhadap Kinerja di Kecamatan Ciampea Kabupaten Bogor. Edutecno. 10 (1), 1-10

Rusman. 2009. Manajemen Kurikulum. Jakarta: PT RajaGrafindo Persada.

Kristiawan, Muhammad dkk. 2017. Manajemen pendidikan. Yogyakarta: CV Budi Utama.

Kristiawan, Muhammad, Manajemen pendidikan (Yogyakarta:Deepublish,2017)

Rusman, Mengemukaan prinsip-prinsip KTSP (Yogyakarta:Deepublish,2011),hlm. 77

Rusman, Manajemen kurikulum (Yogjakarta: Deepublish,2011), hlm. 77

Lestari, Rena. Siklus manajemen (Yogyakarya:Deepublis,2006), hlm.78

Triwiyanto, Teguh (2015).Manajemen Kurikulum dan Pengembangan.Bumi Aksara:Jakarta

Fajartriani, Tia dan Sulfemi, Wahyu Bagja. (2014). Pengaruh Motivasi Kerja Guru dan Iklim Organisasi Terhadap Kinerja Guru SMA Negeri di Kecamatan Cigudeg. Edutecno. 8 (1), 17-26.

Rusman (2009).Manajemen Kurikulum.RajaGrafindo Persada:Jakarta

Hamalik, Oemar(2007).Dasar-Dasar Pengembangan Kurikulum.RemajaRosdakarya: Bandung

Sulfemi, Wahyu Bagja dan Lestari, Ayu Hopilatul. (2017). Korelasi Kompetensi Pedagogik Guru dengan Prestasi Belajar Mata Pelajaran IPS Di SMP Muhammadiyah Pamijahan Kabupaten Bogor. Edutecno. 16 (1), 1-16

Saefullah, Asep dan Rusdiana, Ahmad. (2016). Manajemen Perubahan. Pustaka setia:Bandung

Engkoswara dan A. Komariah. 2010. Administrasi Pendidikan. Bandung: Al-fabeta

Hamalik, Oemar. 2007. Dasar-dasarPengembanganKurikulum. Bandung: Remaja Rosdakarya.

Idi, Abdullah. 2011. Pengembangan Kurikulum Teori dan Praktik. Yogyakarta: Ar-Ruzz Media.

Imron, Ali. 2013. Proses Manajemen Tingkat Satuan Pendidikan. Jakarta: Bumi Aksara

Rusman. 2011. Manajemen Kurikulum. Jakarta: Rajawali Pers.

Soetopo Hendyat dan W. Soemanto. 1991. Pembinaan dan Pengembangan Kurikulum sebagai Substansi Problem Administrasi Pendidikan. Jakarta: Bumi Aksara.

Taba, Hilda. 1962. Curriculum Development, Theory, and Practice. New York: Hercout, Brace and World.

Usman, Husaini. 2010. Manajemen Teori, Praktik, dan Riset Pendidikan. Jakarta: Bumi Aksara 
Rohiat,2008,Manajemen Sekolah; Teori Dasar Dan Praktik.Bandung.Refika Aditama Kompri,2014,Manajemen Sekolah; Teroti Dan Praktek.Bandung.Alfabeta

KArwati Euis,Dan Priansa Doni Juni,2014,Manajemen Kela;:Classroom Management.Bandung.Albeta

Dr.rusman, Manajemen kurikum. Bandung: Rajawali Pers, 2008

Kunandar, Guru Profesional, Jakarta: RajaGrafindo Persada,2007.

Kompri, ManajemenSekolah, Jambi: Alfabeta, 2014.

Hamalik. (2007). Kurikulum dan Pembelajaran. Jakarta: Bumi Aksara

Mulyasa. (2006). Kurikulum tingkat Satuan

Pendidikan. Bandung : Remaja Rosdakarya

Rusman. (2008). Manajemen Kurikulum. Bandung: PT RajaGrafindo Persada

Sukmadinata. (2010).Pengembangan Kurikulum Teori dan Praktek, Bandung: PT Remaja RosdaKarya

Karsiwan, Wawan dan Sulfemi, Wahyu Bagja. (2016). Hubungan Penerimaan Diri Dengan Kinerja Guru SD Di Kecamatan Pamijahan Kabupaten Bogor Edutecno. 15. (1). $1-10$.

Nurdin dan Usman. (2003) Guru Professional dan Implementasi Kurikulum, Jakarta : Ciputat Press

Muhammad, Zaini. (2009). Pengembangan Kurikulum. Yogyakarta: Teras

Azwar, Muhammad. (2016). "peranan Perpustakaan Sekolah dalam Mendukung

Husni, Karna. (2015). Manajemen Perubahan Sekolah. Bandung : CV Pustaka Setia

Kompri. (2014). Manajemen Sekolah Teori dan Praktek. Bandung: Alfabeta CV

Karwati dan Priansa Doni Joni. (2014). Manajemen Kelas. Bandung: Alfabeta CV

Rohiat. (2008). Manajemen Sekolah Teori dan Praktik. Bandung: PT Refika Aditama

Triwiyanto, Teguh. (2015). Manajemen Kurikulum dan Pembelajaran. Jakarta:

PT Bumi Aksara

Syafaruddin, Amiruddin. (2017). Manajemen Kurikulum. Medan: Perdana Publishing

Sanjaya, W. 2009. Kurikulum dan Pembelajaran. Jakarta. Kencana Prenada Media Group.

Sukmadinata, N.S. 2004. Kurikulum dan Pembelajaran Kompetensi. Bandung. Kesuma Karya.

Sahertian, Piet. 1986. Manajemen Sekolah. Malang: IKIP Malang.

Suryosubroto. 2010. Manajemen pendidikan di Sekolah. Jakarta: Rineka Cipta.

Sulfemi, Wahyu Bagja. (2007). Ilmu Sosial Dasar. Bogor: STKIP Muhamadiyah Bogor 
Sulfemi, Wahyu Bagja. (2013). Pengaruh Persepsi Siswa atas Kemampuan Pedagogik Guru dan Motivasi Belajar Siswa Terhadap Prestasi Belajar Ilmu Pengetahuan Sosial Siswa (Survei di SMK Swasta Kabupaten Bogor). Edutecno. 7 (2), 17-26.

Sulfemi, Wahyu Bagja. (2014). Pengaruh Motivasi dan Lingkungan Sekolah Terhadap Prestasi Belajar Sejarah Di SMA Negeri Leuwilang Kabupaten Bogor. Fascho : Kajian Pendidikan dan Sosial Kemasyarakatan 9 (2), 42-52.

Sulfemi, Wahyu Bagja. (2015). Kemampuan Pedagogik Guru. Prosiding Seminar Nasional. STKIP Muhammadiyah Bogor 1. (1). 71-83

Sulfemi, Wahyu Bagja. (2015). Challenges Of Indonesian Teacher Competence in dealing with Asean Economic Cummunity (AEC). Engglis Forum. 1 (1), 69-79

Sulfemi, Wahyu Bagja. (2015). Pengaruh Metode Pembelajaran Kontekstual dan Penggunaan Media Video Pendidikan Terhadap Hasil Belajar IPS. Edutecno. 13 (2), 1-10.

Sulfemi, Wahyu Bagja. (2016). Hubungan antara Persepsi Guru pada Kepemimpian Kepala Sekolah dan Motivasi Guru dengan Kinerja guru dalam Proses Pembelajaran di SMA Negeri 1 Ciomas. Fascho : Kajian Pendidikan dan Sosial Kemasyarakatan, $5(1), 36-55$.

Sulfemi, Wahyu Bagja. (2016). Hubungan Persepsi Peserta Didik Tentang Kompetensi Guru Mata Pelajaran Sejarah dengan Hasil Belajar Mata Pelajaran Sejarah di Kelas X SMA Negeri 1 Pamijahan Kabupaten Bogor. Fascho, 5 (2), 52-70.

Sulfemi, Wahyu Bagja. (2016). Kompetensi Profesionalisme Guru Indonesia dalam Menghadapi MEA. Prosiding Seminar Nasional STKIP Muhammadiyah Bogor. $1(1), 62-77$.

Sulfemi, Wahyu Bagja. (2016). Modul Pembelajaran Ilmu Sosial dan Budaya Dasar. Bogor : STKIP Muhammadiyah Bogor. 1 (1), 62-77.

Sulfemi, Wahyu Bagja. (2016). Hubungan antara Persepsi Guru pada Kepemimpian Kepala Sekolah dan Motivasi Guru dengan Kinerja guru dalam Proses Pembelajaran di SMA Negeri 1 Ciomas. Fascho, 5 (1), 36-55.

Sulfemi, Wahyu Bagja. (2016). Perundang-Undangan Pendidikan. Bogor : Program Studi Administrasi Pendidikan STKIP Muhammadiyah Bogor

Sulfemi, Wahyu Bagja dan Lestari, Ayu Hopilatul. (2017). Korelasi Kompetensi Pedagogik Guru dengan Prestasi Belajar Mata Pelajaran IPS Di SMP Muhammadiyah Pamijahan Kabupaten Bogor. Edutecno. 16 (1), 1-16

Sulfemi, Wahyu Bagja dan Abdul Qodir. (2017). Hubungan Kurikulum 2013 Dengan Motivasi Belajar Peserta Didik Di SMK Pelita Ciampea. Edutecno 17 (2), 1-8

Sulfemi, Wahyu Bagja. (2017). Analisis Pengaruh Motivasi Dan Disiplin Terhadap Kinerja Guru (Studi Kasus di SMA Negeri 1 Pamijahan Kabupaten Kabupaten Bogor). Prosiding Seminar Nasonal STKIP Muhammadiyah Bogor. 1 (1), 342-357.

Departemen Pendidikan Nasional. 2008. Manajemen Sekolah. Jakarta: Pusat Pendidikan dan pelatihan Pegawai.

Triwiyanto, Teguh. 2015. Manajemen Kurikulum. Jakarta : PT Bumi Aksara 
Soetopo, Hidayat dan Wasty Soemarno. 1993. Pembinaan dan Pengembangan Kurikulum : sebagai substansi problem administrasi pendidikan. Jakarta : PT Bumi Aksara

Hernawan, A. H., dkk. (2007). Pengembangan Kurikulum dan Pembelajaran. Jakarta: Universitas Terbuka

Ruhimat, Toto, dkk. (2009). Kurikulum dan Pembelajaran. Bandung : Jurusan Kurtekpen.

Abdulah, Idi. 2007. Pengembangan Kurikulum Teori dan Pratik. Ar RUZZ: Jogjakarta

Ali, M, dkk.(2017). Ilmu dan Aplikasi Pendidikan:Handbook. Bandung:FIP UPI Press.

Tim Dosen Administrasi Pendidikan UPI(...) Manajemen Pendidikan . Bandung. Hal 169165.

Perundang-undangan:

UU nomor 20 tahun 2003 tentang Sisdiknas.

UU Republik Indonesia 13 tahun 2003 tentang Ketenaga Kerjaan pada pasal 1 ayat (10).

UU nomor 20 tahun 2003 tentang Sistem Pendidikan Nasional.

Undang-undang RI no.20 tahun 2003. (2013). tentang sisdiknas dan PP tahun 2010. Bandung : Citra Umbara 